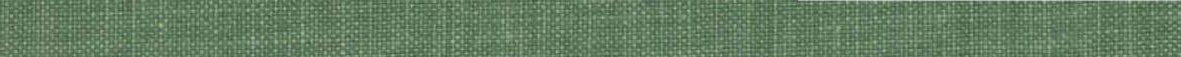





THE VILLAGE WAR 
There are some militarists who say: "We are not interested in politics but only in the profession of arms." It is vital that these simple-minded militarists be made to realize the relationship that exists between politics and military affairs. Military action is a method used to attain a political goal. While military affairs and political affairs are not identical, it is impossible to isolate one from the other.

-Mao Tse-tung, Mao Tse-tung On Guerrilla Warfare 


\section{THE VILLAGE WAR}

VIETNAMESE COMMUNIST REVOLUTIONARY ACTIVITIES IN DINH TUONG PROVINCE 1960-1964

William R. Andrews

University of Missouri Press

Columbia, 1973 
Copyright $\odot 1973$ by The Curators of the University of Missouri University of Missouri Press, Columbia, Missouri 65201

Printed and bound in the United States of America

Library of Congress Catalog Number 73-80584

ISBN $0-8262-0150-4$

All rights reserved 
To those who have struggled in the huts and villages of the world for the dignity of freedom for all men 



\section{CONTENTS}

Preface and Acknowledgments, ix

I. The Peasant and the Party, 1

II. Vietnamese Revolutionary Thought, 20

III. Clandestine Organization, 42

IV. Psychological Preparation of the People, $5^{1}$

V. Expansion of Party Control, 72

VI. Consolidation of Power, 104

VII. The Pattern of Revolutionary Action, 129

Bibliography, 143

Index, 151

Maps

Districts and Major Villages of Dinh Tuong Province, 18

Provinces and Major Cities of South Viet-Nam, 19 

The tongue has no bones; it may be twisted in any direction. -Vietnamese proverb

PREFACE

In a struggle notable for the lack of easily discernible turning points, the years 1960 and 1964 stand as highly visible milestones in the Second Indo-China War. Prior to 1960, the Viet-Nam Dang Lao Dong ("Viet-Nam Workers' Party," the Communist Party of Viet-Nam) maintained guerrilla bases in many parts of rural South Viet-Nam but had not attempted to launch a widespread political movement. In 1960, the Dang Lao Dong formed the National Front for the Liberation of South Viet-Nam (hereafter referred to as the National Liberation Front) in order to mobilize as broad a political spectrum of the Vietnamese population as possible into a revolutionary movement to overthrow the South Vietnamese Government.

By 1964, conditions within South Viet-Nam had deteriorated to such an extent that the United States prepared for a major commitment to shore up the Saigon Government. After 1964, the war in Viet-Nam was "Americanized," with U.S. forces shouldering a large part of the bloody burden of combat. The introduction of these forces, based on the appraisal that they were necessary to preserve a non-Communist South Viet-Nam, altered every aspect of South Vietnamese life and divided U.S. society as had no conflict since the Civil War.

In order to explain how the Dang Lao Dong came to pose a serious threat to the South Vietnamese Government by early 1965 , this work traces the development of the Party revolutionary organization in the rural villages of the key Mekong Delta province of Dinh Tuong. The work was begun with the understanding that the result of such a study would not be a definitive model of the Party's revolutionary process-a model that could apply without exception to all of the South Vietnamese villages-because the often bewildering social and political complexity of the country of South VietNam is reflected in the provinces, districts, and the villages themselves. Yet, through the analysis of the Party's actions 
in the villages of Dinh Tuong, a representative picture of the revolutionary activities of the Party in the villages did emerge. This generalized model is presented as a sequence of four successive phases: clandestine penetration of the village; the psychological conditioning of its inhabitants; expansion of Party control; and, finally, the consolidation of Party social and political gains. Each phase, when successful, formed the supporting structure for the one that followed. In some areas of Dinh Tuong, as in the rest of the nation, local conditions prescribed the intensity of Party effort and the length of each phase.

The picture of the Party-people interface in the villages that appears in this study is bound to please neither the "doves" nor "hawks" of the contemporary United States, because it substantiates few of the cherished notions of either group. The experience of the villages in Dinh Tuong does not support the contention that the Party was intent on building "an egalitarian and participatory society" any more than it supports the claim that the Party was opposed by a majority of the population. What can be seen is that the revolutionary building process was more complex than either gaining the support of a grateful population by elimination of corrupt and oppressive government functionaries and landlords or, on the other hand, applying "terror" to intimidate the villagers into supporting the revolutionary movement.

A major source used in this work was a series of interrogation reports prepared by the Rand Corporation. The interrogation reports contained the testimony of former Party members who worked in the villages of Dinh Tuong Province during the period investigated. In using these reports, three pitfalls had to be avoided. First, there was the natural tendency for the defector, who, after changing coats, believed that he could better his lot by casting the Dang Lao Dong in a bad light. Also, the sources were forced to rely on memory to recall events that, in some cases, had occurred years before. Finally, there was the possibility that the interrogator was not objective and had slanted the respondent's testimony to more nearly coincide with his own particular bias.

Fortunately, the interrogation reports contained a number of interviews of Party members who had been captured, as well as those who had defected from the Party's ranks. Comparisons of interviews of defectors and prisoners did indicate that the defectors' testimony about popular attitudes toward the Dang Lao Dong was colored by the desire 
to please the South Vietnamese Government. However, the same comparisons revealed that both prisoners and defectors agreed on substantive points regarding the actions of the Party in their villages. The cross-checking of interrogation reports of respondents from the same areas in Dinh Tuong Province served to eliminate memory discrepancies. Here, too, the use of dated Party directives tended to corroborate the testimony of the Party members whose duty it was to implement the instructions. That the interrogation reports were prepared by different interrogators may, it is hoped, have lessened the chances that errors were introduced because of individual views and prejudices.

Another major source was a group of more than eight hundred internal documents of the Dang Lao Dong. The documents were collected by Douglas Pike and Jeffrey Race in South Viet-Nam and are part of a collection of Vietnamese materials on file in the Center for Research Libraries in Chicago, Illinois. Taken together, the interrogation reports and these documents provide a fascinating picture of the actions of the Dang Lao Dong in the villages of Dinh Tuong, as well as insights into Party rationale. Other sources include publications of the Vietnamese and Chinese Communist parties, transcripts of articles from North Vietnamese periodicals, and accounts of Vietnamese and Western observers. Other research was conducted in the Pickler Library at Northeast Missouri State University and at Kansas State University. The work that follows is, of course, my own and does not represent the position or views of any department or agency of the United States Government.

W.R.A. Fayetteville, North Carolina May, 1973

\section{ACKNOWLEDGMENTS}

I wish to thank my wife, Elizabeth, for the sustaining gift of her faith and optimism, and Joseph $\mathrm{Ku}$ for his advice and insights. Without them, this work would never have been begun. Finally, to my friend Phung Hiep Chau, my thanks for his patience and courage-virtues that allowed me to know and respect the peasants of South Viet-Nam. 

A general mobilisation of the whole people is neither more nor less than the mobilisation of the rural masses. The problem of land is of decisive importance.

-Vo Nguyen Giap, People's War, People's Army

\section{THE PEASANT}

AND THE PARTY

The conditions prevailing in Dinh Tuong Province in the middle of the twentieth century were due to a unique confluence of demographic, economic, and geographic factors that had been at work for a millennium. After Vietnamese independence was gained from China in A.D. 938, overpopulation in the Red River Delta, commonly called Tonkin, and Chinese pressure from the north spurred expansion in search of new lands. Owing to the Truong Son, a chain of mountains that runs parallel to the South China Sea, emigration was channelled to the south. Villages already established sent groups of pioneers-the young, the restless, the undesirables-to clear uncharted areas for settlement. The settlers, who needed flat land and an abundance of water for cultivation of rice, moved along the coastal plains, avoiding the mountains. Whenever a new group survived and demonstrated self-sufficiency, it achieved the status of a village $(x a)$ and received a name from the emperor. ${ }^{1}$

The march south was soon blocked by the Indianized empire of Champa. The Vietnamese began their struggles against the seafaring Chams in A.D. 982, a series of conflicts that was to last for nearly five hundred years. The only respite for the Chams occurred when Vietnamese attention was di-

1. Gerald C. Hickey, Village in Vietnam, pp. 5-6. 
verted long enough to defeat three invasions mounted by Kublai Khan in the middle of the thirteenth century and invasions by the armies of the second Ming emperor, Yung-lo, at the outset of the fifteenth. By 1471, however, the Vietnamese had sacked the Cham capital of Indrapura and reduced Champa to a vassal state. The emigration southward continued. ${ }^{2}$

The Vietnamese Imperial Court then focused on the southern frontier because of the Champa war, and this focus resulted in a more formal approach to the settlement of new lands. By 1481, the Court had established the don dien, an agricultural-military settlement much like the present-day Israeli kibbutz. Formed for the most part of military veterans, the don dien served to push Vietnamese frontiers further south and at the same time protect the border. ${ }^{3}$ Incentives for expansion included exemption from taxes for the new villages. ${ }^{4}$ It was a period, as the Vietnamese historian Le Thanh Khoi relates, when "the creator of a new village was held in higher esteem than the winner of a battle." 5

Because of a series of weak and incompetent emperors, Viet-Nam became divided and the parts embroiled in a power struggle for imperial supremacy between 1497 and $157^{\circ}$. By the end of this period, three distinct ruling groups had staked out their domains. The Mac family, successors of the court official Mac Dang Dung, ruled from Hanoi, while the central provinces of Thanh Hoa, Nghe An, and Ha Tinh were under control of the Trinh. The Nguyen, with their capital in Quang Tri, were established as rulers in the south. Upon decline of the Mac, the Trinh moved north and, with the support of the Manchu, became recognized by Peking as the legitimate rulers of Tonkin. ${ }^{6}$

The period from 1620 to 1674 saw a brutal war between the Trinh and the Nguyen. During this time, the Nguyen expanded further south, and by 1697 , they had consolidated the gains obtained by the destruction of Champa two hun-

2. D. G. E. Hall, A History of South-East Asia, pp. 198-202.

3. Bernard B. Fall, The Two Viet-Nams, p. 13.

4. Joseph Buttinger, The Smaller Dragon, p. 281.

5. Quoted in Robert L. Sansom, The Economics of Insurgency in the Mekong Delta of Vietnam, p. 21.

6. Hall, History of South-East Asia, pp. 202-4. 


\section{PEASANT AND PARTY}

dred years before and established the southern boundary of the Vietnamese state a little more than one hundred miles north of Saigon. ${ }^{7}$ By the late seventeenth century, the war between the Nguyen and Trinh had resulted in an uneasy peace and the partition of Viet-Nam only a few miles from the demarcation line at the seventeenth parallel established in 1954. The Nguyen, freed from military exertions to the north, were then able to turn their attentions to the Cambodians of the Khmer Empire. The Nguyen ruler, Hien Vuong, formalized expansion westward by creating a bureau of agriculture that was responsible for the settlement of virgin lands. The area around Saigon, the gateway into the Mekong Delta, was sparsely populated by the Cambodians, so the first pioneers met little resistance. Once the Cambodians realized that the Vietnamese constituted a threat of the first magnitude, they attempted armed resistance but failed to hold the land. ${ }^{8}$

It was the Chinese who provided the Vietnamese a casus belli by which they ultimately secured what is now Dinh Tuong Province. In 1679, a large number of Chinese, fleeing the conquest of China by the Manchu, settled near My Tho, now the provincial seat of Dinh Tuong, and took up the trade of river pirates. A minor Cambodian official enlisted the Chinese to help him seize the Khmer throne. When, however, the Chinese proved to be greedy allies, the official was forced to call for Vietnamese assistance to rid him of his then-unwanted friends. The Vietnamese responded with alacrity, defeating the pirates and beheading their leader. As has so often proved to be the case, the allies exacted a heavy price for their help, and by 1698 , Dinh Tuong was opened for establishment of the don dien. ${ }^{9}$ By 1780 , the Vietnamese had laid claim to all the lands that today make up that country. Settlement within these bounds continued until the twentieth century. Camau, the southernmost province, was not declared settled until 1930, nearly a thousand years after the Vietnamese began spilling out of the Red River Delta far to the north. Thus, in the Mekong Delta, it is not difficult to

7. John T. McAlister, Jr., Vietnam: The Origins of Revolution, p. 24 .

8. Hall, History of South-East Asia, pp. 415-21.

9. Ibid., pp. 441-42; Sansom, Economics of Insurgency, p. 7. 


\section{THE VILLAGE WAR}

find men and women still living who founded the last of the pioneer villages. Through the efforts of peasants like these and their forebears, the Mekong Delta, unknown to the Vietnamese in the early seventeenth century, became the home of over nine million people by the middle of the twentieth. ${ }^{10}$

Viet-Nam, as a result of settlement by village unit, was not a centralized state, but rather a "federation of villages." 11 To be sure, the Vietnamese had established the district and province as political echelons between the village and the emperor, but they served only as administrative conveyer belts. The emperor was in charge of the national administration, which was responsible for coordination of the activities of the nearly autonomous villages. Within the village, the most important institution was the Council of Notables. The council dealt with the imperial government, for the central administration did not directly contact the individual villager. Members of the Council of Notables were selected from among the men of the village, and qualifications were based on Confucian standards wherein age and education, rather than wealth, counted. ${ }^{12}$ The autonomy enjoyed by the village was granted out of the Vietnamese Imperial Court's fear that greater control over the villages would erode village stability. Without a firm village foundation, no emperor could expect to maintain what has been defined as a "stable superstructure." ${ }^{13}$ By the middle of the twentieth century, more than twenty-five hundred villages had been formed in South Viet-Nam, and in those villages lived over two-thirds of the nation's population. ${ }^{14}$

The first Western penetration of significance in VietNam was by the Portugese in 1535. Although they, and later the Dutch, affiliated themselves with various rulers, it was not until the nineteenth century that France appeared on the scene as a colonial power. Dispatched to protect Catholic

10. Sansom, Economics of Insurgency, p. 21.

11. Vu Van Thai, "The Development of the Revolution," Asia (Winter, 1966), 23.

12. Paul Mus, "The Role of the Village in Vietnamese Politics," Pacific Affairs, 22 (September, 1949), 266.

13. McAlister, Vietnam, p. 32.

14. Douglas Pike, Viet Cong, p. 110. 
missionaries, a French fleet sailed into Da Nang harbor and fired on Vietnamese vessels in 1847. Further French inroads were delayed because of the Crimean War, but they began in earnest shortly after its conclusion. By 1859, Saigon was in the hands of a French garrison, and in 1862 agreements were signed providing France with three provinces contiguous to Saigon. One of the three was Dinh Tuong. Within five years, all of the Mekong Delta was controlled by the French. They gradually extended their domination northward by various means until, in 1883 , after a guerrilla war against the Chinese Black Flags, all of Viet-Nam had become part of the French Empire. A thousand years of independence had come to an end. ${ }^{15}$

The combination of Vietnamese expansion from north to south and the later colonization by the French from south to north resulted in the creation of a society in southern VietNam markedly different from that in northern Viet-Nam. The Vietnamese who pushed out of the Red River Delta intermarried with Malayo-Indonesians, which caused a considerable ethnographic difference between northern and southern Viet-Nam that exists to this day. ${ }^{16}$ Also, the social institutions of southern Viet-Nam, particularly in the Mekong Delta, were markedly weaker than those in the villages of the Red River Delta. The incursions by the French into an area that had been Vietnamese for only a short time stunted the process of cultural consolidation that had barely begun in the pioneer villages. At the same time, southern scholars and officials retreated to the north to avoid living under French domination; thus, the peasantry lost its natural leaders, and the small Vietnamese middle class that did develop became more closely affiliated with the French than was the case to the north. ${ }^{17}$

Lastly, the capture of the Mekong Delta by the French before traditional economic balances were implemented drastically affected the landholding pattern. The Vietnamese

15. Joseph Buttinger, Vietnam: A Political History, pp. 75-94.

16. An Introduction to Vietnam, p. 8.

17. Fall, Two Viet-Nams, pp. 15-16; Ellen J. Hammer, "Progress Report on Southern Viet Nam," Pacific Affairs, 30 (September, 1957), 222-23. 


\section{THE VILLAGE WAR}

feeling for land is reflected in a traditional ballad which states that "an ounce of earth is worth an ounce of gold." 18 To a Vietnamese, land means far more than a means of livelihood; it enables him to venerate his ancestors by maintaining their tombs in the corner of the paddy, and it assures him that his descendants will be able to provide similarly for his veneration. Ownership of the land takes care of the past, present, and future of the peasant. ${ }^{19}$

Redistribution of land was a part of the imperial function throughout the expansion of the Vietnamese people. During the Later Ly dynasty (1009-1225), the policy of establishing communal lands was begun. The emperor, upon recognizing a new village, granted certain lands to the Council of Notables to be distributed as needed to the population of the village. In 1388, the Tran dynasty decreed that no one could own more than ten mau (approximately twenty-five acres) and that all excess was to be turned back to the government for redistribution as communal lands. Such redistributions were regularized in the eighteenth century and carried out by law each six years. ${ }^{20}$ These land distributions, of course, were carried out only where the emperor's writ was recognized. Systematic redistribution procedures were not implemented in the Mekong Delta before the arrival of the French, and after they arrived, it was impossible. Communal lands still do exist in Viet-Nam, but the decrease in the amount of land per village becomes more pronounced the farther south the village is located. Villages in the northern Mekong Delta still possess communal lands in varying amounts, but in the rest of the Delta, communal lands are found in few villages. ${ }^{21}$

The French colonial administration, once it gained control of the Mekong Delta, sold or gave away huge tracts of land both to French citizens and to urban South Vietnamese who were useful to the French. Large grants were also made

18. Nguyen Be, "Chung Thuy: Study of the New Essence of Life," 81.

19. William Bredo, "Agrarian Reform in Vietnam: Viet Cong and Government of Vietnam Strategies in Conflict," Asian Survey, 10, 8 (August, 1970), 738 .

20. Phuong Anh Trang, "Land Reform of Viet Nam Through History," Vietnam Bulletin, 5 (March 22, 1971), 2-4.

21. Hickey, Village in Vietnam, pp. 14-15. 


\section{PEASANT AND PARTY}

to agricultural corporations, such as the Domaine Agricole de l'Ouest, which received 500,000 acres. Loss of land by the small farmer who was not able to meet his debts also contributed to the landless state of the Mekong peasantry. In spite of the fact that the total area under cultivation in the delta was multiplied tenfold between 1868 and 1930, the expansion offered no relief for the peasant. ${ }^{22}$ By 1945, a situation existed wherein 2.5 per cent of the landowners owned 50 per cent of all cultivable land. In one typical province, 9 per cent of the landowners had title to 70 per cent of the land, and 72 per cent of all farmers owned no land at all. ${ }^{23}$ Throughout the Mekong Delta, more than seven out of ten families depended on tenant farming. ${ }^{24}$

The English historian and economist R. H. Tawney has defined fair land rent as a division of crops between tenant and landlord in proportion to the contribution of each toward meeting expenses. ${ }^{25}$ In terms of this definition, the South Vietnamese tenant farmer received too little, and the landlord too much. Pierre Gourou, a French agricultural economist, provided this picture of a typical tenant's situation in the 1930's:

In the fifth month, at the beginning of the heavy field work, he has obtained from his landlord a loan of 35 gia of rice [approximately 40 bushels] and five piasters. His crop yields 300 gia. From this quantity he must deduct $3^{\circ}$ gia for the extra rice consumed during the harvest time, 70 gia for the repayment of the rice loan of 35 gia ( 100 per cent interest rate), 12.5 gia for the repayment of the five-piaster loan, 150 gia as land rent, or a total of 262.5 gia. There remains only 37.5 gia of his crop, which is little more than 10 per cent of what he has harvested. ${ }^{26}$

Although in-kind rents that amounted to the 50 per cent of the crop yield described by Gourou continued in the late $195^{\circ}$ 's, such high rents were not always levied, nor does the

22. Sansom, Economics of Insurgency, p. 21.

23. Wolf I. Ladejinsky, "Agrarian Reform in the Republic of Vietnam," in Vietnam: Anatomy of a Conflict, ed. by Wesley R. Fishel, p. 519.

24. Roy L. Prosterman, "Land-to-the-Tiller in South Vietnam: The Tables Turn," Asian Survey, 10, 8 (August, 1970), 753.

25. R. H. Tawney, Land and Labor in China, p. 67.

26. Quoted in Ladejinsky, "Agrarian Reform," 520. 
popular picture of absentee landlordism accurately portray the real situation. In the Dinh Tuong area, it was more common for the landlord to charge rents from 30 per cent to 35 per cent of the first crop but to exact no payment for the second crop, thus dropping the over-all rent percentage to below 25 per cent for the year. ${ }^{27}$ Absentee landlords, although there were many, did not constitute a majority of the landholders. A survey conducted by the Stanford Research Institute in 1967 revealed that more than one-third of all landlords lived in the tenant's village, while more than one-half of all landlords lived in the neighboring area. This same survey, which also attempted to judge the tenant's attitude toward the landlord, found that the Vietnamese peasant "evinced no overt hatred of consequence toward his landlord." 28

The landlord, as implied in Gourou's profile, frequently made more money from lending the peasant money than from renting him land. Many peasants borrowed money from friends or relations who charged no interest, but peasants who borrowed from the landlords paid interest rates that ranged from 20 per cent to 120 per cent per year. ${ }^{29}$ The usurious interest rates, combined with high land rents, prevented the peasant from accumulating the money required to purchase his own land. In the total percentage of landlessness, the Mekong Delta ranked among the five worst areas in the world. It is little wonder that the South Vietnamese peasant, in the midst of a long and costly war, mentioned land ownership five times as frequently as peace as a matter of primary importance to himself, his family, and his village. ${ }^{30}$

\section{The Party Genesis}

As the Mekong Delta entered the closing phases of settlement, inchoate political movements began to stir in VietNam. Resistance to French domination had begun with the advent of French attempts to colonize Viet-Nam, but the political mobilization in the first decades of the twentieth century incorporated modern nationalist philosophies, rather

27. Hickey, Village in Vietnam, p. 46.

28. Bredo, "Agrarian Reform in Vietnam," 741.

29. Ladejinsky, "Agrarian Reform," 520.

30. Prosterman, "Land-to-the-Tiller," 753. 
than the traditional one of restoration. Of all modern Vietnamese political movements, no single one was to have more impact in rural South Viet-Nam than that of the MarxistLeninists.

The story of Vietnamese communism is largely the saga of the joining of one man, Ho Chi Minh, with the scattered Vietnamese Marxist revolutionary movements in Viet-Nam and China. Ho provided unity and discipline, forging, over the span of a quarter of a century, a political party remarkable for its apparent stability and organizational ability. From a small nucleus of Marxists in the early 1920's, Ho fashioned a political instrument that destroyed French domination over one of its richest colonies and later directed the war efforts against the governments of South Viet-Nam and the United States.

Ho Chi Minh, born Nguyen Tat Thanh in May 189o, left Viet-Nam in late 1911 as a mess steward on a French ocean liner. ${ }^{31}$ After touching at ports of call in Africa, Europe, and the United States, Ho abandoned the sea to stay in England, where he became an assistant chef to the legendary Escoffier at the luxurious Carlton Hotel in London. ${ }^{32}$ In 1917, Ho went to France and worked as a photograph retoucher. By the end of World War I, he had become a full-fledged member of the Socialist party. He attended the Eighteenth National Congress of the Socialist Party at Tours, which was held from December 25 to December 30, 1920, and made an impassioned speech describing the plight of the Vietnamese who were "oppressed and exploited shamelessly [and] also tortured and poisoned." ${ }^{33}$ His plea for support was answered with only polite applause. Disenchanted with the "ladies and gentlemen" of the Socialist party who did not "side with the colonial people" and who, in his estimation, had no revolutionary consciousness, Ho Chi Minh joined Lenin's Third

31. The most extensive compilation of Ho's many aliases available may be found in King C. Chen, Vietnam and China, 19381954, pp. 37-38 n. 16.

32. Bernard B. Fall, "Ho Chi Minh, Like It or Not," in Man, State and Society in Contemporary Southeast Asia, ed. by Robert O. Tilman, p. 415 .

33. Ho Chi Minh, Ho Chi Minh on Revolution: Selected Writings, 1920-1966, ed. by Bernard B. Fall, p. 21. 


\section{THE VILLAGE WAR}

International and became a founding member of the French Communist Party in $1921 .{ }^{34}$

Ho remained in Paris for three more years gaining experience as a pamphleteer and propagandist. Eventually he was called to Moscow, arriving shortly after Lenin's death in January 1924. He studied at the University of the Peoples of the East and wrote articles for Pravda. In July 1924, Ho addressed the Fifth Comintern Congress, where his identification of the rural Asian peasant, instead of the proletariat, as a revolutionary force anticipated Mao Tse-tung's more publicized "Hunan Report" by three years. ${ }^{35}$ From Moscow, the Comintern sent Ho, who had become an established Party luminary, to Canton, where he was ostensibly to work as the translator for Mikhail Borodin, the Comintern's adviser to Chiang Kai-shek's Kuomintang party. ${ }^{86}$

In actuality, Ho's primary mission in China was to develop the Vietnamese Communist Party. ${ }^{37}$ To this end, Ho, with the assistance of eight other Vietnamese Communists, formed an organization that called itself the Thanh Nien Cong San Doan ("Brigade of Communist Youth"). The Brigade of Communist Youth, which also referred to itself as the Iron Guard, then established a larger organization in order to recruit, organize, and train the large numbers of Vietnamese students who were fleeing to China in the aftermath of the abortive Hanoi Students' Movement of 1925. This new organization, founded in June 1925, was called the Viet-Nam Thanh Nien Cach Mang Dong Chi Hoi ("Association of Revolutionary Vietnamese Youth"), which was shortened to Thanh Nien. ${ }^{38}$

The Thanh Nien was developed along national, rather than international, proletarian lines in keeping with Lenin's pronouncement at the Second Comintern Congress that the Communist vanguard-the Iron Guard in this case-could join in a "temporary alliance" with national movements, provided that the vanguard maintained its own organizational inde-

34. Ibid., pp. 23-24.

35. Ibid., p. 72.

36. Jean Lacouture, Ho Chi Minh, trans. by Peter Wiles, pp. 13-46.

37. J. H. Brimmell, Communism in South East Asia, p. 56.

38. Lacouture, Ho Chi Minh, pp. 48-54. 
pendence within the alliance..$^{39}$ Ho initiated a six-month training course for the Vietnamese emigrés; it ranged from studies in the concept of class-struggle and the Russian Revolution to such technical skills as clandestine production of leaflets and the conduct of mass meetings. After they completed the course, Ho selected the most promising of the students to remain in China with him to form the Thanh Nien Central Committee. The remainder returned to Viet-Nam, established secret cells, and recruited more members, who were sent north to China for a second training course. Among the students remaining with Ho was Pham Van Dong, later Prime Minister for the Democratic Republic of Viet-Nam. ${ }^{40}$

Vo Nguyen Giap, who became the North Vietnamese Minister of Defense, stated that in 1941 it was decided that the Vietnamese Communists would come to power by a "dual" revolution-an initial revolution against the French by all economic classes for national independence and then a second revolution, a class struggle to eliminate the bourgeoisie-but the written records of the Thanh Nien suggest that Ho had laid the groundwork for this decision some sixteen years earlier. ${ }^{41}$ With the founding of the Thanh Nien, Ho published a newsletter of the same name whose initial appeals were of a broad nationalist nature. Later issues took the line that the formation of a Marxist party was a necessity if Viet-Nam was ever to be free of French rule, and then began extensive use of terms and concepts of Communist dialectics that had previously been absent. ${ }^{42}$

During the period of cooperation between the Chinese Communist Party and the Kuomintang, selected members of the Thanh Nien were trained at the Whampoa Military Academy, which operated under the guidance of Mikhail Borodin. When the Kuomintang and the Chinese Communists fell out in 1927, Borodin and Ho Chi Minh were forced to leave China

39. I. Milton Sacks, "The Indigenous Roots of Vietnamese Nationalism," in Vietnam: Anatomy of a Conflict, ed. by Wesley R. Fishel, p. 249.

40. Hoang Van Chi, From Colonialism to Communism: A Case History of North Vietnam, pp. 43-44.

41. Vo Nguyen Giap, The Military Art of People's War, ed. by Russell Stetler, p. 54 .

42. Lacouture, Ho Chi Minh, pp. 48-55. 
and return to Moscow. The Thanh Nien, because it was not openly Communist, was allowed to continue operations in China until December 1928. By that time, its Marxist orientation and contacts with the Chinese Communists had become so apparent that the Thanh Nien Central Committee was forced to move their headquarters to Hong Kong. ${ }^{43}$

During Ho's absence, pressures began to mount to throw off the trappings of nationalism. In May 1929, at a congress of the Thanh Nien, the Tonkin delegation proposed the establishment of an open Marxist-Leninist party. The majority of the delegates felt that this move was premature, whereupon the Tonkin delegates left the congress and announced the formation of the Indochina Communist Party. This so traumatized the remainder of the Thanh Nien that they then announced the establishment of an overt party, the An-Nam Cong San Dang ("Annam Communist Party") in October 1929. To complicate matters further, a rival revolutionary group, the Tan Viet Cach Mang Dang ("Revolutionary Party of the New Viet-Nam"), which had been formed earlier in central and southern Viet-Nam, split into left-wing and rightwing factions. The left wing then became the Dong Duong Cong San Lien Doan ("League of Indochinese Communists"). Thus, by the end of 1929, Viet-Nam's Communists were divided into three mutually hostile camps, much to the benefit of such non-Communist nationalist groups as the VietNam Quoc Dan Dang ("Viet-Nam Nationalist Party," hereafter referred to as the VNQDD), as well as the French secret police. ${ }^{44}$

Rising prices and a shortage of rice in Viet-Nam, largely the result of the worsening economic situation caused by the world-wide depression, prompted the non-Communist VNQDD to take direct action against the French. In February 1930, the VNQDD initiated a piecemeal armed uprising against the French. Although the VNQDD was unsuccessful, the Communists feared loss of prominence as a revolutionary movement if they, too, did not take to the field. Divided as they were, however, they first had to establish party unity. ${ }^{45}$

43. Sacks, "Vietnamese Nationalism," 250-52.

44. Lacouture, Ho Chi Minh, p. 56.

45. Robert J. O'Neill, General Giap: Politician and Strategist, pp. 9-10. 


\section{PEASA N T A D PARTY}

Ho, who from 1927 had been engaged in operations for the Comintern in Germany and Thailand, was sent to Hong Kong to unite the Communist splinter groups. He first reunited the Tonkin and Annam factions that had originally sundered the Thanh Nien, and then worked an accommodation with the left-wing renegades from the Tan Viet Cach Mang Dang. This amalgam, created in the crowd at a soccer match in Hong Kong in February 1930, was called the Viet-Nam Cong San Dang ("Vietnamese Communist Party"). Later in the year, delegates again met in Hong Kong and changed the name to the Dong Duong Cong San Dang ("Indochinese Communist Party," hereafter referred to as the ICP) in order to indicate the true area and extent of their operations. The ICP was accepted as a full-fledged Communist party by the Comintern Executive Committee and subordinated to the Comintern's Far Eastern Bureau. ${ }^{46}$

Even after uniting the Communist elements into a single party, Ho had not fully consolidated his control of the Communists in Viet-Nam. Ho's home province of Nghe An had had three successive bad harvests, and the depression had worked to cut export markets abroad and to raise further the price of rice at home. Famine was prevalent. On May Day, 1930, the peasants of Nghe An and neighboring Ha Tinh Province were led by local Party elements to establish rural soviets, which were then crushed in bloody struggles by the French. Ho Chi Minh was arrested in Shanghai, and 1931 became known in the history of the Vietnamese Communist movement as the Year of the White Terror. ${ }^{47}$ Ho had voted against the establishment of the soviets, but he had been a minority of one. Nonetheless, Stalin blamed Ho for not firmly controlling the Communist apparat and placed the ICP under the direction of Maurice Thorez, a French Communist. ${ }^{48}$ Ho was recalled to Moscow in disgrace upon his release from jail, and of the following years until 1940, there is little substantive knowledge of his activities.

The ICP Congress of 1935, which was held in Macao, marked the end of the recuperative period that followed the

46. Lacouture, Ho Chi Minh, pp. 57-58.

47. Ellen J. Hammer, The Struggle for Indochina: 1940-1955, pp. 85-86.

48. Hoang Van Chi, From Colonialism to Communism, p. 52. 
terror of 1931. In Macao, the ICP received instructions from Moscow that Communist movements in colonial nations were to join forces with non-Communists in order to oppose fascism. The ascendancy of Leon Blum's Popular Front made affliation with the French an easier task for the Vietnamese than was the case in other colonial nations. The ICP was able to move its Central Committee from exile in Thailand to Vietnamese soil and to establish a strong Party network in northern Viet-Nam. When the Popular Front collapsed in 1938, the ICP again became a rogue political movement, but because it was well organized, the Party managed to go underground and survive. ${ }^{49}$

With the Chinese Communists re-allied with Chiang Kai-shek's Kuomintang, China once again provided a sanctuary for Ho Chi Minh. He arrived in southern China in early 1940 and gathered about him the party faithful who had waited for his return. Ho, Pham Van Dong, and Vo Nguyen Giap, all of whom wanted to avoid launching the kind of overt Communist revolutionary movement that had precipitated the terror of the preceding decade, laid plans for the formation of a broad nationalist "united front" that would be controlled by the ICP. Ho and his party then crossed over the border into the Pac Bo area of Viet-Nam in February 1941-for the first time in thirty years, Ho set foot on Vietnamese soil..$^{50}$

Five months before Ho returned to Viet-Nam, the Japanese reached an agreement on the stationing of Japanese forces in Indochina with the French colonial authorities, who by this time were responding to the orders of Vichy. Believing that the Japanese would eliminate French control, Communist groups in the south disregarded Ho's orders and staged an independent uprising in My Tho in November 1940. The Japanese stood by impassively and the French quickly suppressed the movement. The ICP liquidated the two local Communist leaders responsible for the revolt and expelled their subordinates in a purge of the southern branch of the ICP. ${ }^{51}$

On May 19, Ho's fifty-first birthday, the "united front"

49. Hammer, Struggle for Indochina, pp. 90-93.

5o. Chen, Vietnam and China, pp. 44-48.

51. Hammer, Struggle for Indochina, pp. 94-95. 
policy planned by Ho and others in southern China was officially adopted at the Eighth Enlarged Session of the Central Committee of the Indochinese Communist Party, held in Pac Bo. The front, entitled the Viet-Nam Doc Lap Dong Minh ("League for Vietnamese Independence," hereafter referred to as the Viet Minh), from its very birth was a captive creature of the ICP. Although Vo Nguyen Giap was to maintain that the decision made at this time was that national liberation, not socialist revolution, would be the "central and immediate task," this strategic line had been the major thrust of Ho's operations since the founding of the Thanh Nien fourteen years before and also reflected the policy that Mao Tse-tung was then adopting in China. ${ }^{52}$

In the year following its foundation, the Viet Minh successfully established ICP cells in the northern border area of Viet-Nam. In August 1942, Ho disguised himself as a journalist and journeyed to China in order to procure arms and aid from the Chinese Communists and the Kuomintang. ${ }^{53}$ At the same time, the Kuomintang, worried about the dominance of the ICP within the Viet Minh, was preparing a congress for the purpose of pre-empting the Communists in Viet-Nam by rallying non-Communists to form a revolutionary committee as a predecessor of an independent Vietnamese government. To prevent participation by the ICP, Ho was arrested and imprisoned. The resulting Dong Minh Hoi ("Revolutionary League") fell upon hard times without a strong Vietnamese leader capable of holding together the many diverse factions. The Chinese, after tortuous debate, freed Ho Chi Minh on the provision that he reorganize the Dong Minh Hoi under control of the Kuomintang. To this end, Ho convened a Congress of Vietnamese Nationalists in March 1944 and formed a provisional government of which he was the president. True to his agreement with the Chinese, he allowed members of the Viet Minh to hold only a few positions, but these were ones that later proved to be instrumental in maintaining Communist control over the entire body. In essence, Ho formed what one observer described as a "double-decked united front," with the ICP in control

52. Chen, Vietnam and China, pp. 52-53; Vo Nguyen Giap, Military Art, p. 54.

53. Chen, Vietnam and China, pp. 54-55. 
of the Viet Minh, which in turn dominated the provisional government. ${ }^{54}$

The next step taken was the formation of the first armed units. Giap, in response to Ho's expressed desire for military forces with which political goals could be translated into military struggle, suggested that such forces be called the Viet-Nam Liberation Unit. Ho changed the name to the Viet-Nam Propaganda and Liberation Unit in order to indicate the primacy of political action. Borrowing from the military tactics of China's Sun Tzu of the third century B.C., Ho set the style for the employment of the forces: "Be secret, rapid, active, now in the East, now in the West, arriving unexpectedly and leaving unnoticed." 55 The original unit, formed in December 1944, consisted of thirty-four men selected from among local armed groups that had gained battle experience along the China-Viet-Nam border. A number of small actions then followed against the French, all successful, which served more as propaganda than as military victories. ${ }^{56}$

Between the end of World War II and the opening of hostilities between France and the Viet Minh in December 1946, the open existence of the ICP proved to be an impediment to the recruitment of non-Communist Vietnamese into the Viet Minh. Accordingly, Ho Chi Minh officially dissolved the Indochinese Communist Party on November 11, 1945. The ICP, though nonexistent in name, lived on in fact, for that same day, all the former members of the ICP launched the Association for Marxist Studies. ${ }^{57}$

When the ICP went underground, Ho again utilized the "double-decked united front" that he had first unveiled during the war years. This time, the Lien Viet ("National Union of Viet-Nam"), a nationalist front, was secretly controlled by the Viet Minh, which was dominated by the purportedly nonexistent ICP. ${ }^{58}$ Under this cover, the Communists built up the Party strength and at the same time fought

54. Brimmell, Communism in South East Asia, pp. 176-77.

55. Vo Nguyen Giap, Military Art, p. 68.

56. Ibid., pp. 67-70.

57. P. J. Honey, Communism in North Vietnam, p. 12.

58. Michael Charles Conley, The Communist Insurgent Infrastructure in South Vietnam: A Study of Organization and Strategy, U.S. Department of the Army Pamphlet No. 550-106, p. 5. 


\section{PEASANT AND PARTY}

the French. During the period when no Communist Party was officially in being, the Cominform Journal reported that the strength of the Vietnamese Communists had increased from 20,000 in 1946 to 500,000 in 1950.59 Writing of this period, Giap left no doubt that the Communist Party was alive, well, and very much in charge of the entire war effort:

The Vietnamese people's war of liberation was victorious because we had a wide and firm National United Front, comprising all the revolutionary classes, all the nationalities living on Vietnamese soil, all the patriots. This Front was based on the alliance between workers and peasants, under the leadership of the Party [Emphasis added.].60

The ICP held its Eleventh National Congress on February 11, 1951, where the decision was made to emerge into the open again. The Marxist party that arose from the ashes of the ICP underwent a name change and became known as the Viet-Nam Dang Lao Dong ("Viet-Nam Workers' Party," referred to hereafter as the Dang Lao Dong). At the same time, the Viet Minh, which had ostensibly been separate from the Lien Viet, was formally integrated into the Lien Viet. ${ }^{61}$ The elimination of "Indochinese" from the Party's name was a move, as a captured Party document revealed, to alleviate the fears of Laotian and Cambodian nationalists that the Vietnamese, long their traditional enemies, would dominate the neighboring nations. ${ }^{62}$ Thus, by 1951 , the political structure of the Vietnamese Communist movement attained the form that it was to maintain with only minor changes for nearly a decade. Equally important, the resulting political organization had synthesized a body of Marxist revolutionary doctrine that, in Communist parlance, was suited to the "concrete" conditions in Indochina and would later be used in the "liberation" of South Viet-Nam.

59. Honey, Communism in North Vietnam, p. 13.

6o. Vo Nguyen Giap, People's War, People's Army, p. 35.

61. Conley, Communist Insurgent Infrastructure, p. 5.

62. Honey, Communism in North Vietnam, p. 13. 


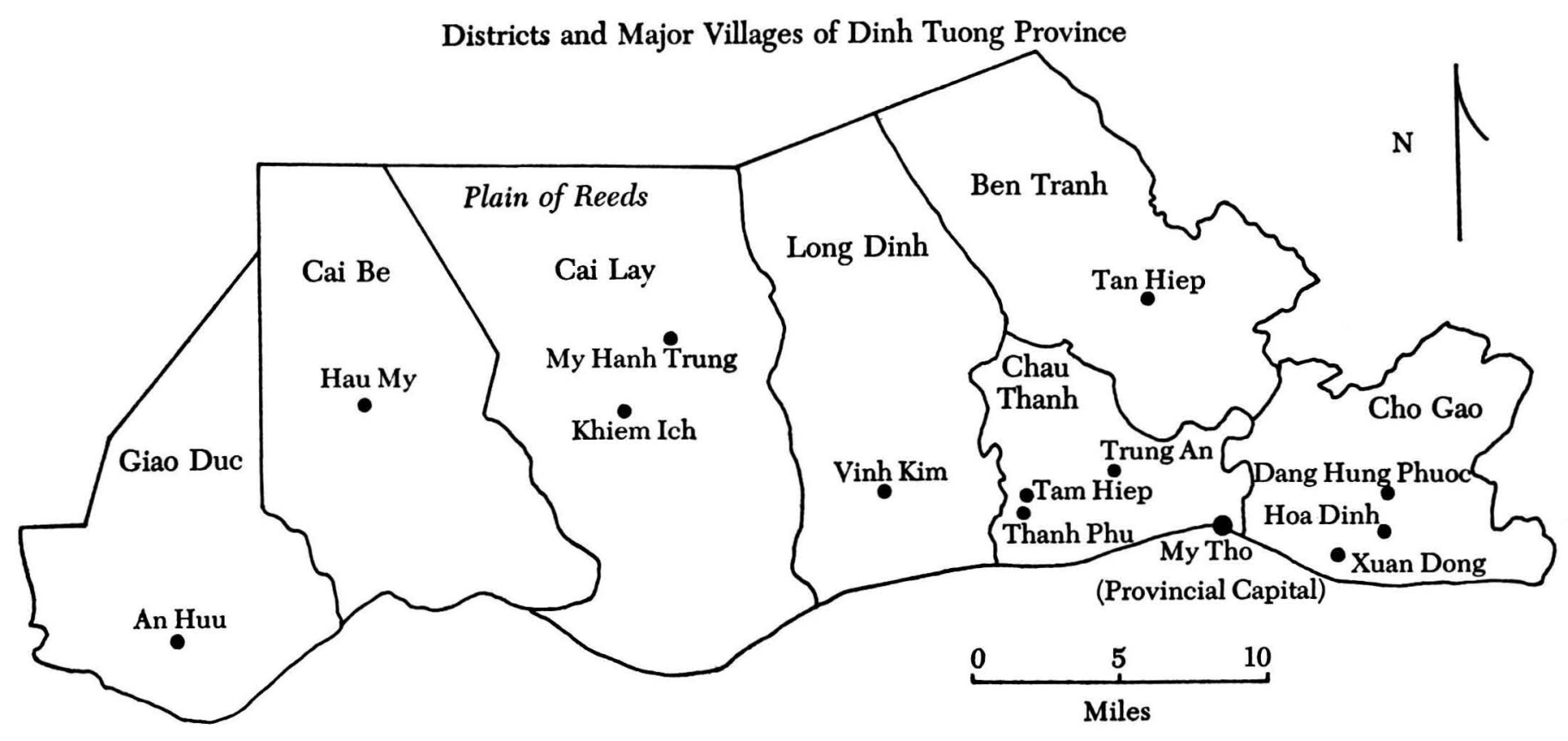


Provinces and Major Cities of South Viet-Nam (Republic of Viet-Nam)

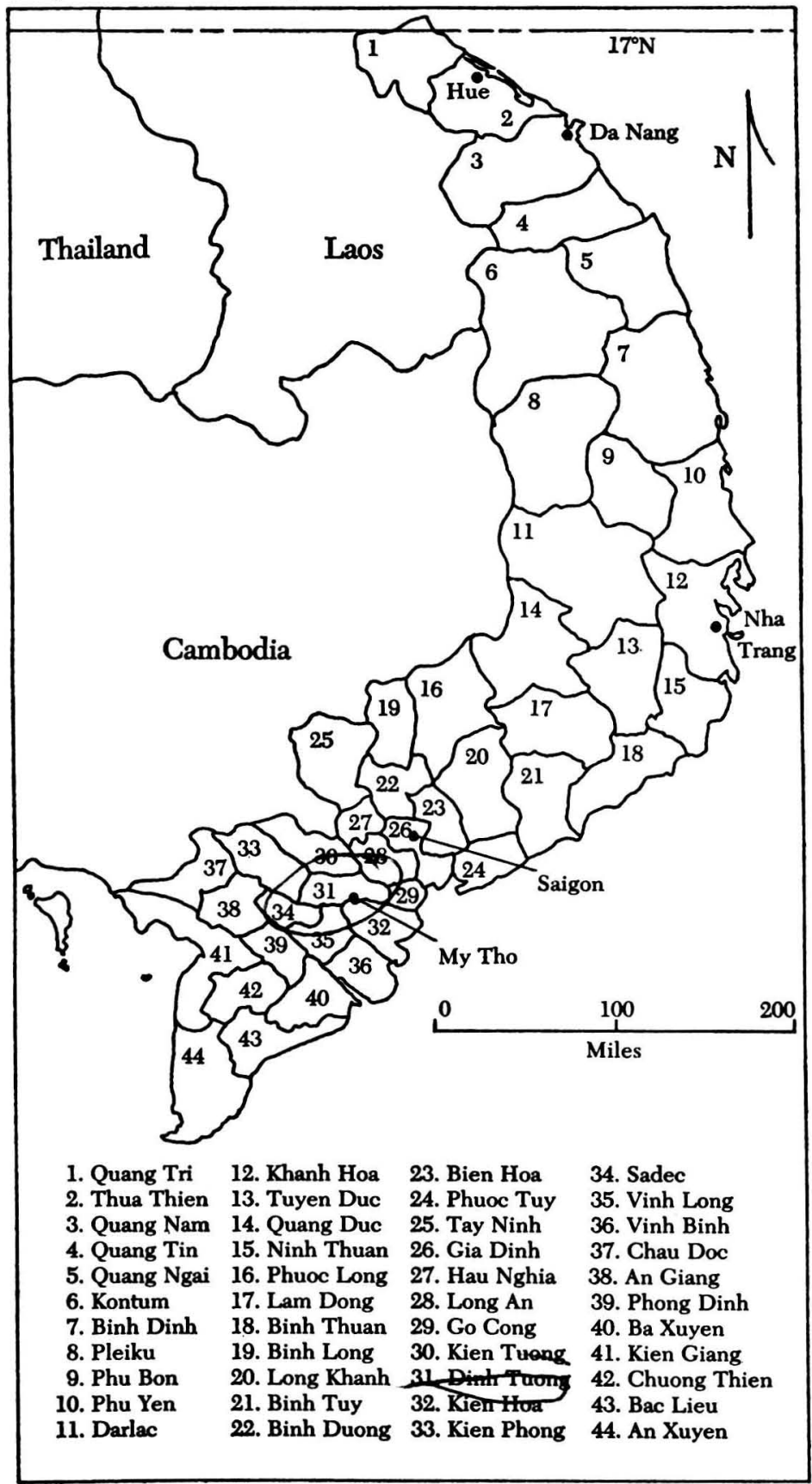


Guerrilla warfare must be the tactic of the people as a whole, not of the army alone.

-Truong Chinh, Primer for Revolt:

The Communist Takeover in Viet-Nam

\section{VIETNAMESE}

\section{REVOLUTIONARY THOUGHT}

The Republic of Viet-Nam was created in part by the outcome of the Geneva Conference of 1954 and in part by non-Communist Vietnamese with aid from the United States and other nations. The South Vietnamese refusal, in 1956, to participate in the plebiscite outlined in the Final Declaration of the Geneva Conference dashed the hopes of Ho Chi Minh to achieve peaceful unification of the two Viet-Nams under the Dang Lao Dong. By 1956, the strength of President Ngo Dinh Diem's political base and the apparent economic progress in South Viet-Nam made the likelihood of the fledgling Government folding upon itself remote. After 1956, it seemed that only force could unite the two halves of Viet-Nam. ${ }^{1}$

A conventional attack by Ho Chi Minh's People's Army of Viet-Nam patterned after the invasion of South Korea probably would have succeeded because the Army of the Republic of Viet-Nam was weak and fragmented, but two factors mitigated against such a move: world opinion and the alternative means possessed by the Dang Lao Dong to destroy the South Vietnamese Government.

Open aggression against South Viet-Nam by the highly trained forces of North Viet-Nam would have resulted in

1. Jeffrey Race, "The Origins of the Second Indochina War," Asian Survey, 10, 5 (May, 1970), 360-63. 
international opinion being marshaled against the Communist regime, for the South Vietnamese had, by assiduous diplomatic effort, established a considerable international presence. The Republic of Viet-Nam was recognized by a large number of nations and had joined every United Nations organization open to it that could not be denied by a Russian veto. $^{2}$ The Democratic Republic of Viet-Nam, on the other hand, had for the most part limited its relations to Communist or "nonaligned" nations. Invasion of South Viet-Nam would have exposed the North Vietnamese to charges of aggression and possibly could have triggered intervention by the United States and her allies. At a time when the Soviet Union was engaged in crushing stirrings of nationalism in Hungary, support of open aggression in Southeast Asia and a confrontation with the Western nations would not be in Russia's interests. In this same period, the North Vietnamese Army was deeply involved in putting down rebellions in Ho Chi Minh's home province, brought on by peasant unrest about a land-reform program gone sour. ${ }^{3}$

The alternative means possessed by the Dang Lao Dong bypassed the difficulties of conventional military action; that means was revolutionary guerrilla warfare. Conditions in South Viet-Nam, no matter how improved, were advantageous for such an undertaking. Diem, far from being a powerful dictator, was actually quite weak, controlling very little of the rural population, much of which was in the hands of armed elements of the Cao Dai and Hoa Hao religious sects. ${ }^{4}$ The slowness and confusion of land redistribution, a necessary reform, offered a ready-made issue for revolutionary exploitation, for distribution of land was an issue far more relevant to the South Vietnamese peasant than the "concentration camp" Executive Decree of $195^{6}$ that sharply curtailed opposition political activities, which were centered mainly in urban South Viet-Nam.

2. Bernard B. Fall, The Two Viet-Nams, pp. 377-78.

3. Hoang Van Chi, From Colonialism to Communism: A Case History of North Vietnam, pp. 224-25.

4. Ellen J. Hammer, "The Limits of Political Action," Pacific Affairs, 35 (Spring, 1962), 24-36; Edward G. Lansdale, "The Cao Dai" (Memorandum to U.S. Ambassador Bunker, Saigon, Viet-Nam, May, 1968), 9-18; Douglas Pike, Viet Cong, p. 80. 
Personnel to wage revolutionary guerrilla war was no problem for the North Vietnamese. A considerable reservoir of native South Vietnamese had been ordered to North VietNam by the Dang Lao Dong during the 300-day period of free travel provided by the Geneva Cease Fire Agreements. Most of these were inexperienced forces-the Communists had left their "hard-core" cadres in South Viet-Nam with orders to go silently underground but to preserve communication networks and maintain weapons in hidden caches. ${ }^{5}$ Ellen Hammer reported that more than 100,00o South Vietnamese were transported to North Viet-Nam during the freetravel period. ${ }^{6}$ Most of these men were of military age and were, a knowledgeable source maintains, formed into two military units, the $33^{\text {oth }}$ and $33^{8}$ th Divisions. The men of

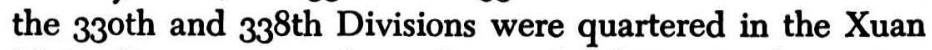
Mai military camp a few miles south of Hanoi, educated in Marxist-Leninist philosophy, and trained in guerrilla warfare techniques. ${ }^{7}$

Communist forces in South Viet-Nam, according to Senator Mike Mansfield in 1955, were "active in infiltration and subversion." Small, armed bands were located in the strategic highlands of central Viet-Nam, Mansfield continued, and in the villages "secret Vietminh village councils have been set up in many areas and function at night in opposition to the regular administration." The Senator concluded in his report that "the Vietminh have in these units a fifth column ready to go into immediate action." 8

Equally as important as proper conditions and sufficient manpower was the Vietnamese doctrine of revolutionary guerrilla warfare, a doctrine studied by few people in the West, except small numbers of French Army officers still stunned from Dien Bien Phu. Insights into Vietnamese Communist revolutionary thought may be gained by first considering the Dang Lao Dong's concept of its own role in the

5. Bernard B. Fall, "Indochina Since Geneva," Pacific Affairs, 28 (September, 1955), 15.

6. Hammer, "Limits of Political Action," 27.

7. Rand Corporation and MACV J-2, File No. DT-101(II), Studies of the National Liberation Front of South Vietnam, pp. 13-24. Cited hereafter as DT-101.

8. U.S. Senate, Committee on Foreign Relations, Viet Nam, Cambodia and Laos: Report by Senator Mike Mansfield, p. 8. 
revolutionary process and then by examining three aspects of that process: the establishment of political control over the rural population as a precondition to destruction of the incumbent government; the requirement that the revolution be a protracted armed political struggle; and the promotion of the idea of a united front as a political instrument. The preceding elements serve to differentiate revolutionary guerrilla warfare from Western military doctrines, which tend to regard civilians in a theater of war as a nuisance to maneuvering units and treat "lightning war" as a desirable objective.

\section{The Party Role in Revolutionary Struggle}

The Vietnamese Communists, in forming their doctrine of revolutionary warfare, have, as they have in other things, borrowed heavily from the Chinese. The recurring theme in the writings of Mao Tse-tung and the Vietnamese Communists is that revolutionary warfare is not spontaneous but is engineered, organized, and led by the Party through all phases. In a remarkably candid and significant article in Nhan Dan ("The People," an official newspaper of the Dang Lao Dong), Vo Nguyen Giap explained the Party's revolutionary mission:

If we desire to execute revolutionary warfare in a systematic and victorious manner, not the least important condition to be considered is the strengthening of the leadership of the Party, which is the vanguard of the working class [Italics in original.].... the peasants who, constantly led and educated by the Party, are imbued with a very high fighting spirit and a completely revolutionary spirit so that all of the conditions are created for moving ahead to meet the new obligations during the revolutionary phase.?

Truong Chinh, former Secretary General of the old Indochinese Communist Party and presently one of the most powerful men in North Viet-Nam, in describing the role of

9. Vo Nguyen Giap, "Understand the Military Policies of the Party and Go On to Win New Victories," reproduced as Vo Nguyen Giap On Understanding the Party's Military Policies, U.S. Department of Commerce, Translations of Political and Sociological Information on North Vietnam, No. 238, pp. 4-5. Cited hereafter as "Military Policies." 
the Party in the struggle against the French, emphasized the importance of Party dominance over such political organizations as "Revolutionary People's Committees" and "Local Liberation Committees," which were used to "paralyze [the French] administrative machine." Truong Chinh declared that the founding and subsequent manipulation of such organizations was "characteristic of the communist tactics." 10

Early in the struggle against the French, the Viet Minh published directions for establishing Local Liberation Committees under the title "Instructions of the General Committee." The Liberation Committees were composed of persons elected by secret ballot and then charged with governing the population in the revolutionary areas. Prior to elections, the instructions stated, local Party officials would "determine the number of candidates who are to be put forward" and thus eliminate those who might prove difficult to handle in the future. ${ }^{11}$ The General Committee then dictated the manner in which the Liberation Committees were to be controlled:

The Viet Minh will direct the Liberation Committees by means of "Viet Minh sections." Viet Minh representatives in each Liberation Committee will form a "Viet Minh section" of the Committee. The Viet Minh section will meet on the eve of each session of the Committee in order to determine its stand on various questions on the agenda. ${ }^{12}$

The stand of the Viet Minh section was based on instructions from local Party leaders who were not members of the Liberation Committees and who, in turn, had received their own instructions from the Party hierarchy above them. In essence, the Dang Lao Dong perceived itself as the only legitimate leader of the Vietnamese revolutionary struggle. Vo Nguyen Giap left no doubt about this when he stated that revolutionary guerrilla warfare "is a force of all the people that partici-

10. Truong Chinh, Primer for Revolt: The Communist Takeover in Viet-Nam, pp. 26-27.

11. Rima Rathausky, ed., Documents of the August 1945 Revolution, pp. 4-5.

12. Ibid., p. 6. 
pates in uprisings and wars in an organized manner under the Party's vanguard leadership." 13

\section{Party Political Control Over the Rural Population}

While much attention in the West has been focused on the guerrilla military tactics employed by the Vietnamese Communist revolutionaries, the political mobilization of the Vietnamese population has received scant systematic treatment save from a handful of specialists. Guerrilla military tactics alone are neither new in military history nor limited to Southeast Asia. Descriptions of guerrilla campaigns can be found in accounts of Napoleon's conquest of Spain, in the ballads about South Carolina's "Swamp Fox," Francis Marion, and in the writings of China's Sun Tzu. Rather, it was the political mobilization of the population by the Vietnamese Communist revolutionaries, which led to the intermingling of military and civilian Party elements down to and including those in the Vietnamese village, that was unique-a political relationship totally alien to the West.

The Vietnamese, like the Chinese Communists, were forced to adapt Marxist-Leninist doctrines to fit the demographic situation at hand. The Vietnamese proletariat had too few people to be the mainspring for revolution. Giap and others reserved this role for the peasantry, Giap declaring that in Viet-Nam, political mobilization of the masses meant essentially a mobilization of the rural masses. ${ }^{14}$ An early document of the Dang Lao Dong described the peasant as "the axletree of the Revolution. ... Control this axletree and one can move everything,"15 and the Vietnamese Communists later identified the rural village as "the fundamental unit of people's war." 16

The Dang Lao Dong hoped to extend control over the rural population in a series of successive reinforcing phases that would culminate in the establishment of a militarized socialist society. Within this society, all persons either would

13. Vo Nguyen Giap, Banner of People's War, the Party's Military Line, p. 28.

14. Vo Nguyen Giap, People's War, People's Army, p. 27.

15. Pike, Viet Cong, p. 167.

16. Vo Nguyen Giap, Banner of People's War, p. 103. 
be members of the "people's militia" or would support paramilitary units in other ways. Within this society, the Party would exercise absolute leadership, with Party cadre observing all aspects of the people's lives. ${ }^{17}$ The very lack of such sociopolitical control in the southern part of Viet-Nam during the First Indochina War was attributed by Truong Chinh as the reason for the Party's failure to consolidate all the nation after the defeat of the French in $1954 .^{18}$ Vo Nguyen Giap described the process of establishing a political control:

[The] years of decisive political struggle [1] from the time of the establishment of our Party, [2] the arousing and [3] organizing of the masses ... and the upgrading of the Party's leadership role, were years of preparing forces for [4] the armed revolutionary struggle. ${ }^{19}$

A 1959 Dang Lao Dong directive outlined the steps to be taken in establishing the Party in a selected target area. First, investigation of the military, political, economic, and social situation had to be conducted by covert agents. Then propaganda work was to be initiated in order to prepare the population for the establishment of Party-controlled front organizations. Third, the organizational work would begin among the population. Finally, after the population was enmeshed in the Party organizations, it would be led into various mixes of military and political actions against the South Vietnamese Government. ${ }^{20}$

The application of this process by the Party in South Viet-Nam was described in another captured document, a report on the progress of the Party in a village bearing the encrypted name "XB":

In XB, the Party made careful advance preparations; the people were well educated and mobilized prior to the launching of the mass movement and the start of

17. Le Nam Thang, "Grasp Basic Principles of People's War," reproduced, U.S. Department of Commerce, Translations of Political and Sociological Information on North Vietnam, No. 237, p. 37 .

18. Truong Chinh, Primer for Revolt, p. 36.

19. Vo Nguyen Giap, "Military Policies," 10.

20. Vietnamese Communist Document $75 \mathrm{~A}$, "Five Rules to Follow," pp. 1-10. 
the building of the combat village. Once started, everything progressed quickly and smoothly. ${ }^{21}$

The first sentence contains a summary of the phases described by Giap. The Party made its own "advance preparations," working in a clandestine fashion. The population was then "well educated" in regard to Party goals, which could be tailored to fit the political demands of the moment. After the educational process had paved the way, the Party began to expand the scope of revolutionary activities, engaging the non-Party villagers in the "launching of the mass movement." Militarization soon followed when the population became involved in the construction of village fortifications and the concurrent building of the village self-defense militia. From bases so established, the Party could then move into new locations, a strategy described by Lin Piao as reliance upon the peasantry to build rural bases and, using these bases, to encircle and finally capture the cities. ${ }^{22}$

To the Party, battles were not to be fought for the sole purpose of causing casualties among the opposition or for seizing and holding critical terrain. The major battlefield was to be in the rural villages of South Viet-Nam and in the minds of their inhabitants. Military policy was subordinate to Party policy at every level, and Party policy was dictated by political, not military, considerations. In the words of one experienced Western observer, "The armed element was not the [Party's] determinative body; it was an instrument through which policy was implemented." ${ }^{23}$ Vo Nguyen Giap succinctly emphasized this relationship when he wrote:

The military policy of the Party is a policy of systematic revolutionary warfare of the people which aims at the achievement of the political policies of the Party [Italics in original.] . . . . The military policy

21. Vietnamese Communist Document 2, "Experiences in Turning XB Village in Kien Phong Province into a Combatant Village," p. 64. Cited hereafter as VCD 2.

22. Lin Piao, "Long Live the Victory of People's Warl" Peking Review, 36 (September 3, 1965), 14-16.

23. Michael Charles Conley, The Communist Insurgent Infrastructure in South Vietnam: A Study of Organization and Strategy, U.S. Department of the Army Pamphlet No. 550-106, p. 118. 
always is a result of the political policy of the Party and is subordinate to that policy. ${ }^{24}$

The key objective was to convince the rural population of South Viet-Nam of the Dang Lao Dong's legitimacy as a functioning government. With the rural population under control of the Party, the Government in Saigon would thus become essentially the Government of Saigon alone and thus irrelevant to the great majority of the South Vietnamese people. To the Party, control of the population was the raison d'être for military action. Vo Nguyen Giap described strong local support as "a permanent element of success," underscoring the phrase in order to emphasize the importance he attached to the rural civil population in waging a successful revolutionary war. ${ }^{25}$ Through strong local support, the population provided the revolutionary with fresh manpower, logistics support, and information about the activities of the incumbent government. With this power furnished by the population, the revolutionaries could then expand their operations, gathering in ever larger numbers of the previously uncommitted population to their political control.

It follows, then, that if control of the population is a major element of success, the loss of that control would doom the revolutionary movement. Mao Tse-tung recognized this and warned of "losing" the population:

Without a political goal, guerrilla warfare must fail, as it must if its political objectives do not coincide with the aspirations of the people and their sympathy, cooperation, and assistance cannot be gained... The moment that this war ... dissociates itself from the masses of the people is the precise moment that it dissociates itself from the hope of ultimate victory. ${ }^{26}$

A former Party member in South Viet-Nam, who had been responsible for the implementation of policy at the village level, spoke of the future of the Dang Lao Dong in the event that it could no longer control the rural population in the areas it presently dominated:

24. Vo Nguyen Giap, "Military Policies," 4.

25. Ibid., 17.

26. Mao Tse-tung, Mao Tse-tung On Guerrilla Warfare, ed. and trans. by Samuel B. Griffith, p. 43. 


\section{REVOLUTIONARY THOUGHT}

If the [Party] was separated from the people, how could it have money to feed its soldiers and workers to do manual labor for it? Without the people, the [Party] would die. ${ }^{27}$

The importance of the support of the rural peasants was the subject of thorough indoctrination down to the lowest levels of military forces. Those South Vietnamese in training in the Xuan Mai camp were warned that they should maintain respect for and good relations with the Party apparatus in the villages. One member of the 33oth Division recalled his instructor explaining in considerable detail that it was only due to the Party control of the population that Communist forces could be stationed in the villages. He added, "The Party teaches that the army can be strong only if the organizations in the village are strong," and said that after he had returned to South Viet-Nam, he saw that such was the case. $^{28}$

The Vietnamese Communist revolutionaries were not so fixed upon gaining the following of the peasant that they advocated outright elimination of landlordism as a political platform. On the contrary, they demonstrated that they were flexible and were quite capable of soft-pedaling their Marxist intentions in order to attain short-term political gains. The Indochinese Communist Party, when weak, needed all the support it could muster from as broad a cross section of Vietnamese society as possible. Political expediency, not ideological orthodoxy, was the reason that, in Truong Chinh's words:

the Indochinese Communist Party, promoter and leader of the Viet Minh Front, left out of its programme the watchword: Agrarian revolution, (deciding for the present, not to confiscate land held by landlords) and this with a view to winning a number of them over to the anti-imperialist cause. ${ }^{29}$

Such a temporary accommodation was consistent with Ho Chi Minh's policy that the Party, in the early stages of strug-

27. Rand Corporation and MACV J-2, File No. DT-79 (1), Studies of the National Liberation Front of South Vietnam, p. 19. Cited hereafter as DT-79.

28. DT-101, p. 34 .

29. Truong Chinh, Primer for Revolt, p. 21. 
gle, should stand publicly only for such "democratic rights" as freedom of speech, assembly, and suffrage. At the same time, Ho warned that talk of Marxist class struggle should be muted for the present; instead, the Party should maintain what he described as a "wise, flexible attitude with the bourgeoisie" in order to obtain the maximum support from the landlord classes until the Party had eliminated the French and could then move to the second stage of the socialist revolution. ${ }^{30}$

In the second stage, the bourgeoisie, whose support had been used to rid the country of the French, would be eliminated as a class. This plan was made clear before the fact when Truong Chinh defined the "double character" of the revolution:

First, it must be an anti-imperialist revolution [Italics in original.] aimed at overthrowing the imperialist domination, and second, it must be an agrarian revolution [Italics in original.] so as to confiscate the lands of the feudal landlords and distribute them to the peasants. $^{31}$

The second stage in North Viet-Nam began after the French left and in $195^{6}$ resulted in the virtual elimination of the bourgeoisie through a "land reform" program planned and executed by Truong Chinh. In what one Western observer called an "indescribable butchery," more than 100,000 persons were executed or imprisoned. ${ }^{32}$ The Dang Lao Dong in its struggle to overthrow the Government of South Viet-Nam held Truong Chinh's view of the revolution. The Party perceived two "basic contradictions" that had to be solved by revolutionary struggle: the "contradiction between the Vietnamese people and the imperialists, especially the United States imperialists and their lackeys," and the "contradiction between the masses, especially between the farmers and feudalist landlords." In light of this concept, the twofold mission of the Party was "to annihilate the American Imperialists

3o. Ho Chi Minh, Ho Chi Minh on Revolution: Selected Writings, 1920-1966, ed. by Bernard B. Fall, pp. 131-32.

31. Truong Chinh, Primer for Revolt, p. 45 .

32. Gerard Tongas, L'enfer Communiste du Nord Vietnam, p. 222. 


\section{REVOLUTIONARY THOUGHT}

and their lackeys, and to erase all vestiges of feudalism ... . lin order to] pave the way for the establishment of socialism." ${ }^{33}$

\section{Protracted Struggle}

The necessity for protracted revolutionary struggle was explained by Mao Tse-tung in his work On The Protracted War, but the factors that required of revolutionaries a struggle of such length predated Mao Tse-tung and the Asian Marxist milieu. Traditionally, a revolutionary was a revolutionary because nonviolent means for change either did not exist or were not accessible to the revolutionary. The revolutionary, therefore, had to resort to violence. Plans and preparations could be made in secret, but the same secrecy that shrouded and protected the nucleus of a revolutionary movement also served to hamper its growth, for in order to grow, the fledgling movement had to attract new believers, convince them, and put them to work. The revolutionary, therefore, was required to lift the shield of secrecy, at least a little, after the groundwork had been laid. Once partially emerged, he was exposed to suppression or elimination by the incumbent government. To survive, the revolutionary needed somehow to avoid a decisive defeat at the hands of his enemy, but at the same time, he had to continue to enlist the aid of others in order to increase his power.

As dangerous as this process is, a number of advantages accrue to the revolutionary who treads the long path to authority and legitimacy. Those persons not strongly motivated tend to fall by the wayside, leaving the revolutionary organization weaker in numbers but stronger in the quality of determined, tempered members. Protracted struggle also provides the time necessary for the movement's members to reach some kind of accord about what programs they are to implement should they come to power. The organization will be able to identify and eliminate those who are unable to reach a consensus, thus ensuring that internal divisiveness will not plague the movement. If, for some reason, the established

33. Vietnamese Communist Document 737, "Resolution on Motivating the People in Bien Hoa Province," p. 6. Cited hereafter as VCD 737 . 
government falls before the dissenting revolutionaries have been purged from the movement and internal cohesion achieved, anarchy and further bloodshed may result because the revolutionary organization is too undisciplined to take on the demanding task of handling the governmental functions of the state. ${ }^{34}$

To the above considerations, the Chinese and Vietnamese Communist revolutionary leaders added the rationale that at the outset, the enemy enjoys certain relative advantages while the revolutionary possesses several absolute advantages. The relative advantages of the enemy must be reduced and those absolute advantages of the Party-led masses enhanced. Writing of the anti-Japanese "War of Resistance," Mao Tse-tung outlined the advantages and disadvantages of both sides, which appear below: ${ }^{35}$

\section{JAPAN}

\section{Disadvantages:}

1. War fought for imperialist gain; a "a retrogressive war.

2. Limited manpower and material resources; inadequate to fight a prolonged war.

3. Lack of international support save from the remote Axis powers.

\section{Advantage:}

1. Present military strength.

\section{CHINA}

Advantages:

1. War fought for just and "progressive" reasons.

2. Sufficient manpower and material resources upon which a prolonged war might be waged. support.

3. Strong international

\section{Disadvantage:} weakness.

Mao asserted that only through protracted struggle may the balance be shifted, that the one advantage that has given the reactionary enemy his initial success can be reduced, whereas the absolute advantages of the revolutionary can be strengthened. It was from this doctrinal standpoint that Mao was to make his famous "paper tiger" statement:

34. Carl Leiden and Karl M. Schmitt, The Politics of Violence: Revolution in the Modern World, p. 122.

35. Lin Piao, "Long Live the Victory of People's Warl" 11; Mao Tse-tung, On The Protracted War (Peking: Foreign Languages Press, 1954), p. 20. 


\section{REVOLUTIONARY THOUGHT}

All reactionaries are paper tigers. In appearance, the reactionaries are terrifying, but in reality they are not so powerful. From a long-term point of view, it is not the reactionaries but the people who are really powerful [Emphasis added.]. ${ }^{36}$

More than twenty-five years after Mao had compared the weaknesses of reactionary Japan and progressive China, Vo Nguyen Giap's article in Nhan Dan contained a strikingly similar rationale for prolonged revolutionary struggle:

People's war, from our viewpoint, should occur when we have a decided political advantage over the enemy and the enemy is stronger than us from a material standpoint. Based on the revolutionary nature of the war and detailed comparisons of the forces of both sides, our military technique which has evolved is based on the strategic concept of carrying on a war of all the people, on all the fronts, for a long time. We must undergo a long period of warfare to develop political preponderance and to gradually fortify and strengthen our forces. We must develop the weak into strong, change the power ratio between the enemy and ourselves and bring the war to a victorious conclusion. ${ }^{37}$

In a single-sentence paragraph in his work The Resistance Will Win, Truong Chinh stated in boldface type, "The guiding principle of the strategy of our whole resistance must be to prolong the war." 38 Truong Chinh, in the passages following this statement, repeated, in an order almost identical to that of Mao Tse-tung, the advantage-disadvantage formula. Truong Chinh, however, devoted considerably more attention to the probable effects of protracted struggle on the domestic scene in France:

If we prolong the war, thanks to our efforts, our forces will grow stronger, the enemy forces will be weakened, their already low morale will become still lower, their already poor finances will become still poorer. The more we fight, the more united our people at home will be, and the more the world democratic movement will support us from the outside. On the other hand, the

36. Mao Tse-tung, "Talk with the American Correspondent Anna Louise Strong," in Selected Works, IV, p. 100.

37. Vo Nguyen Giap, "Military Policies," 15.

38. Truong Chinh, Primer for Revolt, p. 111. 
more the enemy fights, the more the antiwar and democratic movement in France will check his hands. ${ }^{30}$

Later in The Resistance Will Win, Truong Chinh returned to the externalization of the revolutionary movement as a means of reducing French military strength:

The French have many modern arms, numerous and well-trained officers and troops ... but their war is an aggressive war, so they have few friends and many enemies, suffer from internal division, and cannot enjoy support of the people; their effective strength is constantly diminished.... The more the enemy fights the more critical his financial and economic situation. The more we fight, the more we enjoy the support and sympathy of the French people and peace-loving peoples the world over. ${ }^{40}$

According to the Sino-Vietnamese doctrine, the nature of the revolutionary struggle would not remain the same throughout but would change at certain points, according to the balance of power. In People's War, People's Army, the first of his works to be widely received in the West, Giap described three phases:

Our strategy was, as we have stressed, to wage a longlasting battle. A war of this nature in general entails several phases; in principle, starting from a stage of contention, it goes through a period of equilibrium before arriving at a general counteroffensive. ... Only a long-term war could enable us to utilise to the maximum our political trump cards, to overcome our material handicap and to transform our weakness into strength. ${ }^{41}$

Ho Chi Minh described the first stage as a period when the Party preserved itself and increased its military forces. During this phase, guerrilla tactics were emphasized. The second stage consisted of those actions directed toward active contention with the enemy. Guerrilla and conventional tactics would be used where applicable. The final stage, that of the general counteroffensive, would see the formation of many large units and the ultimate defeat of remaining enemy

39. Ibid., p. 112.

40. Ibid., pp. 166-67.

41. Vo Nguyen Giap, People's War, People's Army, p. 29. 


\section{REVOLUTIONARY THOUGHT}

forces in conventional battle..$^{42}$ By the time the third stage would be reached, the battle that ensued would not be one between giants but, rather, one in which the revolutionary military forces have grown strong and the governmental forces weak-in the third stage the revolutionary forces would administer the coup de grâce to an already reeling and crushed opponent. Mao Tse-tung envisioned this in the following manner:

While these units function as guerrillas, they may be compared to innumerable gnats, which, by biting a giant in front and in rear, ultimately exhaust him. They make themselves as unendurable as a group of cruel and hateful devils, and as they grow and attain gigantic proportions [Emphasis added.], they will find that their victim is not only exhausted, but practically perishing. ${ }^{43}$

The timing of moves from contention to equilibrium and from equilibrium to general counteroffense was a subject to which the Vietnamese Communists paid close attention. Giap, whose premature move to conventional tactics against Marshal de Lattre de Tassigny caused a series of neardisastrous defeats for the Vietnamese insurgents, ${ }^{44}$ later wrote of the importance of timing:

The shifting from political struggle to armed struggle was a very great change that required a long period of preparation. If insurrection is said to be an art, the main content of this art is to know how to give the struggle forms appropriate to the political situation at each stage. ${ }^{45}$

The building of military units is a process that dovetails neatly into the Sino-Vietnamese concept of graduated protracted warfare. Beginning from an initial military strength of nearly zero in relation to the enemy, the revolutionary must construct an instrument that simultaneously promotes and protects Party political work among the rural population. Mao Tse-tung built revolutionary forces on three levels:

42. Ho Chi Minh, Selected Writings, p. 198.

43. Mao Tse-tung, On Guerrilla Warfare, p. 54.

44. Edgar O'Ballance, The Indo-China War, 1945-1954: A Study in Guerrilla Warfare, pp. 120-39.

45. Vo Nguyen Giap, People's War, People's Army, p. 76. 
the small village unit, the local forces, and finally, the mainforce units. At each level, moving from smaller to larger, the quality of discipline, training, and equipment increased. ${ }^{46}$ Village-level forces, less well trained and armed than others, performed guard duties and, being limited to the area immediate to their homes, very restricted offensive operations. The members of such forces were a mixture of full-time village guerrillas and part-time self-defense militia who supported themselves and their families through farming or other activities. Local forces, better armed and trained than the village units, had a greater range of action but were smaller in size than the main-force units and were provided less support in the form of heavy weapons and specialized units. The main-force units, like the local forces, were professional, in the sense that they were paid and were full-time fighters. Main-force units provided the military strength to engage the regular army units of the incumbent government.

Vietnamese revolutionary doctrine called first for the establishment of village forces. In theory, the best fighters in the village forces would become the core of the local forces. The local forces, once battle proven, would provide their most talented personnel to form the nuclei for main-force units. ${ }^{47}$ This upward building process was necessary because the Vietnamese lacked military experience. The French had, for many years, excluded Vietnamese from participating in, and training for, commands of great responsibility. The organizational tools by which large military units could be formed, trained, and committed in combat had to be developed and forged in battle, in what Mao Tse-tung referred to as the "university of war." 48

\section{The United Front}

In order to gain support from as broad a cross section of South Vietnamese society as possible and to arouse support for the revolutionary movement in non-Communist nations, the Dang Lao Dong went to considerable pains to encourage

46. Mao Tse-tung, On Guerrilla Warfare, pp. 78-79.

47. Vo Nguyen Giap, Banner of People's War, pp. 32-34.

48. Mao Tse-tung, On Guerrilla Warfare, p. 73. 
the fiction that the revolutionary struggle in South Viet-Nam represented the will of the population and that the Dang Lao Dong was only one of the many organizations comprising a united front. In the context of Sino-Vietnamese Communist doctrine, the united front was not a means of joining those with similar goals and differing political or social backgrounds into a constructive coalition; rather, it was an organizational device-an instrument by which the Party's policy would, in the end, be implemented.

Lin Piao recounted the usefulness of the united front in the struggle against the Japanese, declaring that in order to win, the Party had to build the "widest possible" front in order to encompass the largest number of the nation's classes. ${ }^{49}$ As might be deduced from Truong Chinh's analysis of the dual nature of revolutionary struggle, the front's greatest usefulness to the Party was in the first stage of people's war. The united front, ostensibly in charge of the conduct of the struggle, could espouse "liberal" platforms that were different from the Party's actual goals. Where Marxist doctrine demanded the confiscation of land, the front was able to soften this demand to rent reduction. In the first stage of struggle, the Party could make a great point of its flexibility by apparent concessions and affect a façade of reasonableness. After the revolution against "imperialism" was won, the Party could then shed the front and its reformist policies and proceed to implement its own more radical programs. The Vietnamese concept of the function of the united front was similar to that of Lin Piao, who explained:

A Communist Party must hold aloft the national banner and, using the weapon of the united front [Emphasis added.], rally around itself the masses. . . . History shows that within the united front, the Communist Party must maintain its ideological, political and organizational independence, adhere to the principle of independence and initiative, and insist on its leading role [Emphasis added.]. ${ }^{50}$

In South Viet-Nam, the Dang Lao Dong created an extra-Party united front in a similar fashion to the Viet Minh.

49. Lin Piao, "Long Live the Victory of People's Warl" 12.

50. Ibid., 14. 
In May 1959, the Dang Lao Dong Central Committee announced that "the time has come to struggle heroically and perseveringly to smash" the South Vietnamese Government. ${ }^{51}$ By the middle of 1960 , nearly one-third of the members of the 33oth and 338th Divisions at Xuan Mai had been infiltrated back to their native South Viet-Nam. ${ }^{52}$ At the same time, Party organization in South Viet-Nam was being transformed into a sophisticated command apparatus. This restructuring included construction of party committees at village, district, and provincial levels. ${ }^{53}$ In September 1960, the Third Party Congress of the Dang Lao Dong announced its intention to involve itself in the struggle to "liberate" South Viet-Nam. ${ }^{54}$ In order to achieve this objective, the First Secretary of the Dang Lao Dong, Le Duan, called for the formation of a "broad united front." 55

Radio Hanoi, in late January 1961, announced that "various forces opposing the fascist Ngo Dinh Diem regime" had established the Mat Tran Dan Toc Giai Phong Mien Nam Viet Nam ("National Front for the Liberation of South VietNam," hereafter referred to as the NLF) on December 20, $1960 .{ }^{56}$ Hanoi was aided in its attempt to present the NLF as a coalition of a number of mass organizations, some of which were the Communist elements, by such writers as Wilfred Burchett, who claimed that the member organizations of the united front had been in independent existence long before the NLF was created. ${ }^{57}$ In actuality, the opposite was true. The Women's Liberation Association, purportedly a revolutionary organization independent of the Dang Lao Dong, was founded well over three months after the NLF came into being. The Youth Liberation Association was not founded for more than a year after formation of the Front. As Douglas Pike has observed, the "NLF reversed the usual order for front formation; instead of beginning with

51. Pike, Viet Cong, p. $78 . \quad 52$. DT-101, p. 13.

53. Conley, Communist Insurgent Infrastructure, p. 43.

54. Ibid., p. 15.

55. George A. Carver, Jr., "The Real Revolution in South Viet-Nam," Foreign Affairs, 43 (April, 1965), 406.

56. George A. Carver, Jr., "The Faceless Viet Cong," Foreign Affairs, 44 (April, 1966), 361 .

57. Wilfred G. Burchett, Vietnam: Inside Story of the Guerrilla War, pp. 185-87. 
the organizations and creating the front, it began with the front and [then] created the organizations." 58

The National Liberation Front was organized into regional People's Liberation Committees similar to the Local Liberation Committees the Viet Minh used against the French, with subordinate committees at the provincial, district, and village levels. As in the Viet Minh committees, overt Party participation was limited. In the NLF, open representation of the Dang Lao Dong was restricted to not more than two-fifths of the total membership of that committee. ${ }^{59}$

Running parallel to the hierarchy of the NLF was the Dang Lao Dong structure, which managed, through the overt Party members in the Front and covert cells throughout the NLF, to control the Front at all levels. In addition to the People's Liberation Committees, the Dang Lao Dong maintained sole control over armed forces recruited under the aegis of the NLF. A simplified version of the organization of the National Liberation Front and the Dang Lao Dong appears in Figure 1.

To maintain the illusion that the Front and the Dang Lao Dong were separate and independent entities, it was announced from Hanoi on January 20, 1962, that a conference of Marxist-Leninists had taken place on December 19, 1961, in South Viet-Nam and had formed the Dang Nhan Dan Cach Mang Viet Nam ("People's Revolutionary Party," hereafter referred to as PRP), then had decided to join the National Liberation Front to aid in the fight against the Government of Ngo Dinh Diem. ${ }^{60}$ That this statement was an attempt to conceal the Dang Lao Dong's creation and domination of the NLF is evident from the contents of a document originated by the provincial Party Committee of Ba Xuyen Province. Dated December 7, 1961, nearly two weeks before the alleged meeting of the South Vietnamese "Marxist-Leninists" that formed the PRP, the document read:

To D2 and K [Subordinate elements, probably District Party Committees]

In regard to the foundation of the People's Revolutionary Party of South Vietnam, the creation of this

58. Pike, Viet Cong, p. 110.

59. Carver, "Faceless Viet Cong," 368-69.

6o. Fall, Two Viet-Nams, p. 357 . 
Figure 1. Relationship of the Dang Lao Dong to the Communist-controlled military forces and to the National Liberation Front

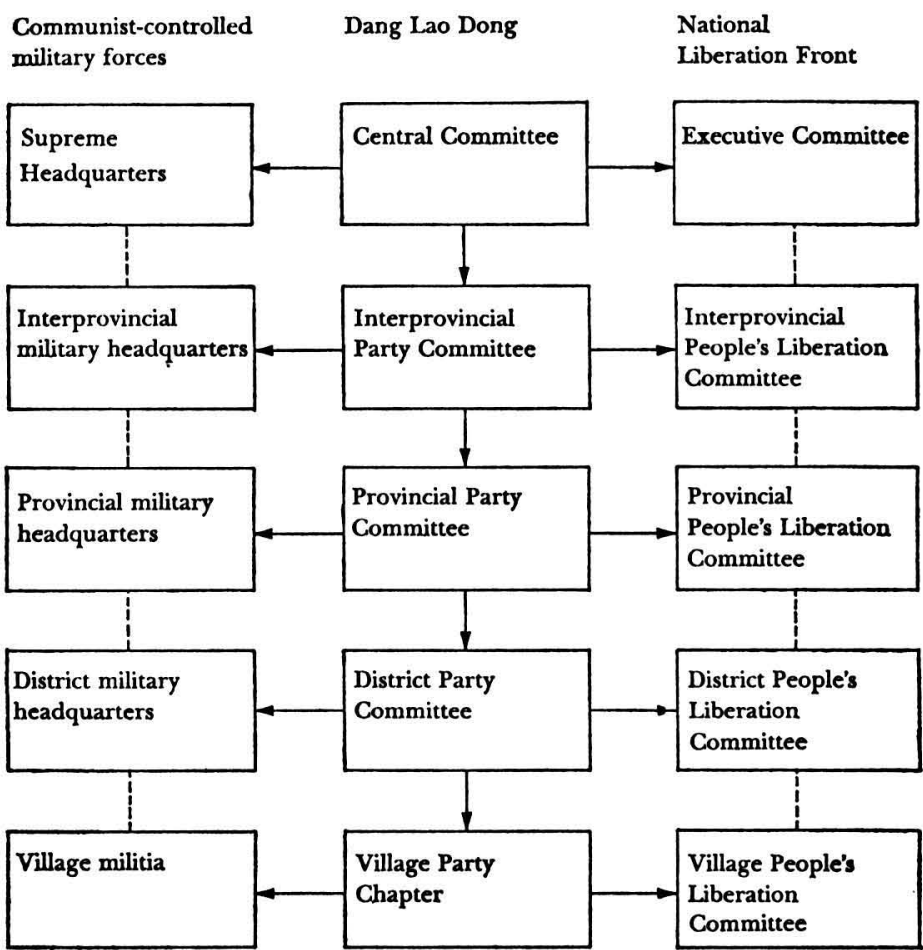

Control channels

Coordination channels - - - - - -

SourcE: Conley, Communist Insurgent Infrastructure, 165. 


\section{REVOLUTIONARY THOUGHT}

party is only a matter of strategy; it needs to be explained within the Party; and, to deceive the enemy, it is necessary that the new party be given the outward appearance corresponding to a division of the party [Dang Lao Dong] into two and the foundation of a new party, so that the enemy cannot use it in his propaganda.

The People's Revolutionary Party has only the appearance of an independent existence; actually, our party is nothing but the Lao Dong Party of Vietnam, unified from North to South, under the direction of the central executive committee of the party, the chief of which is President Ho. ${ }^{61}$

Perhaps one of the most lucid portrayals of the interrelationship between the PRP and the National Liberation Front is one made by Douglas Pike:

The People's Revolutionary Party ... acts like the reinforcing rods in a ferroconcrete wall. For a graphic representation of their relationship, picture the NLF as a broad-based pyramid with the villages at the bottom and the central committee at the top, and the PRP as a thinner and harder core pyramid within, but also rising from base to apex. ${ }^{62}$

This, then, is a brief picture of the National Liberation Front, a political instrument created by the Dang Lao Dong and controlled by the southern branch of the Dang Lao Dong, which called itself the People's Revolutionary Party. This was the instrument the Vietnamese Communists used to pre-empt the Diem Government in the rural villages of South Viet-Nam.

61. U.S. Department of State, Aggression from the North: The Record of North Viet-Nam's Campaign to Conquer South VietNam, Department of State Publication No. 1839, p. 57.

62. Douglas Pike, "How Strong is the NLF?" The Reporter, 34 (February 24, 1966), 21. 
In the heavily controlled areas by the enemies, in order to protect the Party, the Party's organizations must keep the principle of secrecy.

-Dang Lao Dong Directive,

Vietnamese Communist Document 50

\section{CLANDESTINE ORGANIZATION}

Clandestine political activity is a tradition of long standing in Viet-Nam. For hundreds of years, aspirants to power cloaked their intentions for justifiable fear of repression. The climate in which secret plots and plans were nurtured was created, as Douglas Pike has observed, by

the Vietnamese assumption that society consisted of dangerous and conflicting social forces with which only enigmatic organization ... could cope. Power in old Viet-Nam was something to be fought for, to be seized and clung to exclusively. No emperor ever willingly shared it. A challenger to the throne hid his hand until he was ready to strike. ${ }^{1}$

French disruption of the traditional protodemocratic processes within the Vietnamese village ensured that clandestine politics, formerly limited to the Imperial Court, became a way of life in the village. To the villagers of Dinh Tuong inculcated in furtive struggles, the initial operations of the Dang Lao Dong were not new, even when refined to a degree undreamed of by other political groups.

The purpose of the clandestine organizational phase in the modus operandi of the Dang Lao Dong was to establish Party cells within a target village; from these cells would

1. Douglas Pike, Viet Cong, p. 9. 


\section{CLANDESTINE ORGANIZATION}

come further development of the Party, which would in turn establish and control the united front, or, in the case of South Viet-Nam, the National Liberation Front. During this entire process, the village cadre was extremely vulnerable; he had to assume that the world he was about to enter was hostile, that Government agents and enemies were everywhere, awaiting his first mistake. Too, he might become the victim of a villager, for Viet-Nam, after decades of internecine strife is a land where many people, irrespective of political coloration, have any number of old scores to settle.

To the Dang Lao Dong cadre, Dinh Tuong was divided into three parts: the "large liberated area," the "temporarily liberated area," and the "contested area." The liberated area was defined as that area firmly under control of the Party at all times, save, perhaps, for brief incursions by Government troops from "outside." The "temporarily liberated area" was composed of villages in which the presence of Government forces denied the Party full control. The "contested areas" were those in which the Government had its strongest forces and exercised strong control over the population. ${ }^{2}$ By virtue of this semantic exercise, the Dang Lao Dong sought to establish its pre-eminence by refusing to admit openly that the Government of South Viet-Nam had any base areas at all. In actuality, the bulk of those clandestine organizational activities designed to pave the way for extension of the Front took place in the "temporarily liberated" areas, and clandestine activities in the "contested" areas were largely restricted to covert intelligence and sporadic actions.

In the rural areas of Dinh Tuong where the Viet Minh had been strongest, the trained Party members who did not regroup to North Viet-Nam in 1954-1955 remained in their villages. By early 1955 , they were being formed into clandestine cells. ${ }^{3}$ The Dang Lao Dong told these elements that the period up to the anticipated plebiscite in 1956 would be one wherein the struggle for unification would be in the political,

2. Rand Corporation and MACV J-2, File No. DT-86 (I), Studies of the National Liberation Front of South Vietnam, pp. 12-13. Cited hereafter as DT-86.

3. Rand Corporation and MACV J-2, File No. DT-49 (III), Studies of the National Liberation Front of South Vietnam, p. 2. Cited hereafter as DT-49. 
rather than the military, arena. Perhaps fearing the adverse effect on the cadre morale at lower levels, the Party never mentioned that it did not expect that the elections would be held. Knowledge of the Party's expectations was restricted to a few select province-level Party members. ${ }^{4}$ Instead, the Party passed instructions to district and village cadre to wait patiently while strengthening the internal Party leadership in the "liberated" areas and maintaining the Party communication-liaison nets between the villages and higher echelons. ${ }^{5}$

The period from 1956 to 1960 was a desperate one for the Dang Lao Dong; the Diem Government continued to arrest many suspected Party members. In spite of the over-all ineffectiveness of the Diem Government, it was able in the early days of the struggle to restrict the operations of the Dang Lao Dong. In one village in Dinh Tuong, all twenty members of the Party had been arrested and imprisoned by mid-1958. ${ }^{6}$ In order to preserve itself, the Party in Dinh Tuong established base areas in the north of that province within the forbidding Plain of Reeds, which was not greatly affected by the security cordons thrown up by the government. ${ }^{7}$

At the outset, it was these base areas from which the Dinh Tuong cadre were required to work. Sometimes accompanied by guerrillas, the cadre traveled to the selected villages, conducted their initial missions, and then returned to the relative security of the "liberated" zones. When required to operate from outside the village, the Dang Lao Dong formed a village area-specialist team, a kind of Village Party Committee in exile, which was in charge of establishing the Party presence. It was not unusual to find such a group headed by a Party asset-a Party member native to the village who had kept his affliation secret and who directed the efforts of the team through clandestine means while he still lived in the village. ${ }^{8}$

4. P. J. Honey, Communism in North Vietnam, p. 6; Jeffrey Race, "The Origins of the Second Indochina War," Asian Survey, 10, 5 (May, 1970), 361.

5. Rand Corporation and MACV J-2, File No. DT-69 Supplement, Studies of the National Liberation Front of South Vietnam, pp. 3-4. Cited hereafter as DT-69.

6. DT-49, p. 2.

7. Race Document 1006, pp. 1-3.

8. Rand Corporation and MACV J-2, File No. DT-99 (I), 


\section{CLANDESTINE ORGANIZATION}

On the other hand, it was common for the committee chief to move into the base area and supervise the operations from there. ${ }^{9}$ In party parlance, this latter operation was called tu the vot can cau ("line-casting position"), a colorful word image alluding to the fisherman who, by staying in one place, casts his line in hope of catching a fish in a more distant location. ${ }^{10}$ The initial target would be a certain village, and once selected, the village itself was penetrated piecemeal. For instance, one Party member described his village as one consisting of nine hamlets. Of the nine hamlets, four were under Party control, three were "contested," that is, under Government control, and two were located in the "temporarily liberated" category. ${ }^{11}$

The first task of such an itinerant cadre team was to conduct surveys of the target village. The survey determined the problems to be anticipated, such as large concentrations of Catholics or families of persons serving in the Government armed forces. A captured Party document specified the areas to be examined:

1. Geographical position, terrain, population; is it situated near communication lines, plantations, military bases, etc.?

2. Enemy situation [Presence of Government]: administrative committee, police, militia, spies, etc. Schemes and activities of above mentioned organizations; activities of upper-level men coming to the village: (cadres coming to carry out communism denouncing tasks, collect taxes, carry out community development, ... etc.); internal discord; attitude in executing [Government] orders.

3. Masses situation: Classes, social strata, circles, religions, habits and costumes, cultural standards....

4. [Strength of Party members]: thought, morale, revolutionary ability. ${ }^{12}$

Studies of the National Liberation Front of South Vietnam, p. 18. Cited hereafter as DT-99.

9. DT-79, p. 1.

10. Rand Corporation and MACV J-2, File No. DT-108 (I), Studies of the National Liberation Front of South Vietnam, p. 12. Cited hereafter as DT-108.

11. DT-49, p. 1.

12. Vietnamese Communist Document 75, "Five Rules to Follow," p. 8. Cited hereafter as VCD 75. 
Points 2 and 3 of the above requirements were most strongly emphasized by village cadre in Dinh Tuong Province. Although cadre sources varied to some degree in describing much of the format of their surveys, they were consistent in the analysis of the class structure of the villages in which they lived and worked. The categories utilized by the Party cadre in analyzing the situation in their villages followed those discussed by Mao Tse-tung in his article, "How to Differentiate the Classes in the Rural Areas": landlords, rich peasants, middle peasants, poor peasants, landless peasants. ${ }^{13}$ One such analysis by a captured Party member gave the breakdown of his village as follows: ${ }^{14}$

\begin{tabular}{|c|c|}
\hline $\begin{array}{l}\text { Landlords } \\
\text { (dia chu) }\end{array}$ & 3 persons \\
\hline $\begin{array}{l}\text { Rich farmers } \\
\quad \text { (phu nong) }\end{array}$ & 20 persons \\
\hline $\begin{array}{l}\text { Middle farmers } \\
\quad \text { (trung nong) }\end{array}$ & $40 \%$ of village population \\
\hline $\begin{array}{l}\text { Poor farmers } \\
\quad \text { (ban nong) }\end{array}$ & $45 \%$ of village population \\
\hline $\begin{array}{l}\text { Very poor farmers } \\
\text { (ban co nong) }\end{array}$ & $15 \%$ of village population \\
\hline
\end{tabular}

In making an analysis of the class structure of the village, the Party classified a farmer as a landlord if he owned land but did not till it himself, regardless of the size of his holdings. A peasant who had considerably more acreage but who tilled the land was identified as a rich farmer. The value of such an analysis can be appreciated when it is coupled with the Party's estimate that the poor and very poor farmers would support the revolution. If the analysis were substantially correct and the Party's assumption valid, the majority of the residents in the village described above could be expected to provide support for the struggle against the Government.

The military portions of the survey did not differ appreciably from conventional Western military assessments of the areas. Generally, the farther the village was away from

13. Mao Tse-tung, "How to Differentiate the Classes in the Rural Areas," in Selected Works, I, pp. 137-39.

14. DT-49, p. 8; VCD 737, p. 1. 


\section{CLANDESTINE ORGANIZATION}

lines of communication and military bases, the better. Where Government troops were stationed in the area, their movement patterns were observed and noted, strength levels checked, and attention paid to reaction time of any reinforcements. In the event that military force was to be used, the District Party Committee could use its local forces or, if these were insufficient, main-force units from the province could be called upon. ${ }^{15}$

If the results of the initial survey indicated that Government presence was nonexistent or weak, a single cadre cell of three to five persons was sent to work in the village. Once there, it undertook the major mission of the clandestine organizational phase, recruiting. One Party recruiter who was active in 1956 listed members of the families of South Vietnamese who had relatives in the Party, persons who had family problems, and those in debt or in trouble with the law as potential recruits. ${ }^{16}$ Cadre were instructed to consider the more popular young people in the village as future recruits and to sound them out, knowing that if recruitment were successful, they could bring in many of their friends. All recruits were subjected, unknowingly for the most part, to thorough background investigations before the cadres tipped their hands. ${ }^{17}$

In the clandestine phase, Party cadre concentrated mainly on gaining new Party members from among the lowerincome classes and from among the youth. Marxist doctrine aside, such a policy was based upon sound psychology. The minds of those with little or no education were less likely to be cluttered with ideas that might conflict with Party ideology, and as one observer pointed out, the "structuring of reality quite often leaves a long-lasting impression, particularly when it is imbedded by incessant repetition, and gives voice to inchoate political urges which have hitherto been unable to find expression." ${ }^{18}$ It might appear that recruiting

15. Rand Corporation and MACV J-2, File No. DT-59 (I), Studies of the National Liberation Front of South Vietnam, p. 5 . Cited hereafter as DT-59.

16. W. P. Davison, Some Observations on Viet Cong Operations in the Villages, pp. 14-15.

17. Pike, Viet Cong, p. 81.

18. David W. P. Elliott and W. A. Stewart, Pacification and the Viet Cong System in Dinh Tuong: 1966-1967, p. 14. 


\section{THE VILLAGE WAR}

in the first stage of the struggle in the village was an insurmountable problem, given the conditions under which the cadre had to work. However, recruiting great numbers of villagers was not the objective. This distrust of great numbers can be illustrated by the Party's own standards of what constituted a sufficient number of Dang Lao Dong members in a village already under Party control:

A village having 300 [adult males] of whom 7 are party members ... may be considered very active. We can say that the Party Chapter in that village has done a good job. ${ }^{19}$

After recruiting and educating a small number of villagers, the first cell was formed within the village and was referred to as the village Party ban can su ("Civil Affairs Committee"). ${ }^{20}$ The Civil Affairs Committee was usually composed of those Party members who were natives of the village who established the committee and their new recruits. On some occasions, the Party had to resort to using Party members from outside the village to serve permanently within the village, but doing so brought mixed results. ${ }^{21}$ The Civil Affairs Committee represented the Party nucleus within the village, the seed that, if conditions were right and care exercised, would be the precursor to an expanded presence at some future date. The Dang Lao Dong proved to be patient in expanding beyond this phase; one source from Tam Hiep village in Dinh Tuong declared that the existence of a Civil Affairs Committee had been kept secret from the villagers for two years. ${ }^{22}$

The success or failure of the Civil Affairs Committee depended upon the security system it established for the personal safety of its members and for its communications with higher echelons. This security system remained in effect even after the village passed into control of the Party. Members of the committee hid their status from their neigh-

19. "Report on the Regional Activities of the K Village Party Chapter," quoted in Michael Charles Conley, The Communist Insurgent Infrastructure in South Vietnam: A Study of Organization and Strategy, U.S. Department of the Army Pamphlet No. 550-106, p. 377 .

20. DT-108, p. 63.

22. DT-59, p. 4 .

21. DT-79, p. 7. 


\section{CLANDESTINE ORGANIZATION}

bors, friends, and, in some cases, their wives. ${ }^{23}$ To prevent capture or death, Party cadre, if given sufficient warning, disappeared from the village when Government troops threatened to enter the area. If surprised, they resorted to the use of carefully prepared hiding places. These hide-outs were separated in such a way that each cell had its own, which was kept secret from other cells. ${ }^{24}$

The village Civil Affairs Committee secretary, a potentially disastrous source of information if he fell into enemy hands, usually did not go into hiding until all other members of the committee had done so in order to prevent his subordinates from divulging his location if they were captured..$^{25}$ Such measures were physically and mentally taxing, as the description of one village cadre indicates:

We often hid ourselves in ditches in places covered by foliage. We kept only our nose above the water to breathe. There was also another way of hiding. This was to go into ... the underground caches. But the latter method was the most depressing one because every [cache] was filled with water. We could not stay there more than six or seven hours. That was why [we] greatly feared the sweep operations which lasted for a full day. ${ }^{26}$

Communications between the higher echelons and the village Civil Affairs Committee in written form were maintained by a painstakingly secure method. The Civil Affairs Committee placed its outgoing mail in a certain location designated beforehand; often it used a clay jar buried in the ground and carefully camouflaged. A courier from the district committee would later empty the "mailbox," carry the messages to yet another clay jar near the district Party Committee headquarters, deposit them, and then leave. Letters and instructions from district to village were transmitted in the same manner. Careful cadre ensured that the same locations were not used over a long period of time. Government

23. Rand Corporation and MACV J-2, File No. DT-61 (III), Studies of the National Liberation Front of South Vietnam, p. 14. Cited hereafter as DT-61.

24. Rand Corporation and MACV J-2, File No. DT-8o (II), Studies of the National Liberation Front of South Vietnam, p. 16. Cited hereafter as DT-80.

25. DT-86, p. 18.

26. Ibid. 
forces apprehending the courier en route would, of course, capture the documents, which were often encrypted, but could get no further up or down the organizational chain because the courier did not know the identity of either the sender or the recipient. ${ }^{27}$

All too often the Party cadre who worked in a clandestine fashion has received a bad press in the West due to his methods-methods that were dictated largely by his relative weakness. Ideological considerations aside, the determination and courage of the Party village cadre should never be doubted. The following excerpt from a Party Report illustrates the tenacity of the Party in establishing the first cell in the village referred to as " $\mathrm{XB}$ ":

During the first few years of peace the Party made several attempts to step up its activities. Three times its organization was destroyed by the enemy. Three Party members were killed, two secretaries arrested. ... Finally only one Party member remained and he was driven onto the beach.

In 1959, cadres from the higher level arrived to gather the scattered Party members and instruct them in the reestablishment of the destroyed party base. Things were so difficult, at that time, that our comrades were forced to hide in the fields and marshes during the day and only at night could they slip into the village to do propaganda work among the farmers. ... A base was soon established at a farm.... Gradually our victories convinced some of the farmers and we were able to bring into being the XB Party, consisting of seven members [Emphasis added.]. ${ }^{28}$

On the early efforts of the cadre in the clandestine phase, the Party built its future bases. Without this small beginning, the rest that was to follow could never have been.

27. DT-69, p. 5 .

28. VCD 2, p. 2. 
Of course, not all the prerequisites for a revolution are going to be created solely by guerrillas. Certain minimum preconditions are needed to kindle the first spark. The people must be shown that social wrongs are not going to be redressed by civil means alone.

-Ernesto "Che" Guevara, Guerrilla Warfare

\section{PSYCHOLOGICAL PREPARATION OF THE PEOPLE}

After penetrating the village, the Dang Lao Dong set about to destroy the "social adhesive" that had traditionally integrated the villager into his society and provided him with a sense of identity. The strategy of the Party was designed to illustrate that the customary elements of authority and leadership in the peasant's world were bankrupt, that they were unable to provide meaningful solutions to the problems facing the village and its inhabitants and were therefore undeserving of loyalty. The tactics of the Dang Lao Dong were to capitalize on local discontent, to magnify real or imagined grievances of the population, and to offer solutions to the issues raised. The solutions invariably provided a rationale for the restructuring of the society under the leadership of the Party, as well as motivation for the individual to support the Party's actions.

\section{Party Strategy: Elimination of Traditional Leadership}

Thomas Perry Thornton has argued that those techniques intended to disrupt a society must be directed not at individuals, but toward the institutional keystones that support 
the individual in times of crisis. Only if the keystones are destroyed will the social structure collapse and open the way for construction of a new order on the ruins of the old. ${ }^{1}$ In the world of the average rural Vietnamese, there were two keystones: the somewhat haphazard presence of the South Vietnamese Government, which was attempting to establish itself from above and, more importantly, the traditional internal relationships within the village. The Party, in its prelude to political take-over, destroyed the former and initiated processes that altered the latter in a way that created situations in which the old behavioral norms offered no workable solutions to problems confronting the villagerproblems that caused profound personal isolation and disorientation. In another manner of speaking, it was the Party's intent to interrupt the traditional social rhythm of the village and then to cause that resonant mass, the peasantry, to become attuned to the beat of another, a new rhythm, the tempo of which was controlled by the Party.

Among the first elements to be organized within the village by the Civil Affairs Committee were the Ban An Ninh ("security section") and the Ban Tuyen Huan ("propaganda section"). The propaganda section was further divided into subsections, with one cadre responsible for propaganda, another for cultural affairs, and a third for education, which included establishment of schools within the village. ${ }^{2}$ The propaganda section was headed by a Party member and contained from three to five persons. ${ }^{3}$ During the psychological preparation phase, the security section worked very closely with the propaganda section.

In his work On Guerrilla Warfare, Mao Tse-tung defined three distinct types of revolutionary psychological activities -those "first, as applied to the troops; second, as applied to the people; and third, as applied to the enemy." " The Dang

1. Thomas Perry Thornton, "Terror as a Weapon of Political Agitation," in Internal War, ed. by Harry Eckstein, p. 77.

2. Rand Corporation and MACV J-2, File No. DT-57 (III), Studies of the National Liberation Front of South Vietnam, p. 11.

3. Vietnamese Communist Document 130, Directive on Information, Propaganda, Education and Cultural Activities for 1961, pp. 65-66.

4. Mao Tse-tung, Mao Tse-tung On Guerrilla Warfare, ed. and trans. by Samuel B. Griffith, p. 90. 
Lao Dong also divided its operations along similar lines: dich van ("action among the enemy"), that is, operations conducted against those rural Vietnamese controlled by the South Vietnamese Government; dan van ("action among the people"), meaning activities among the Vietnamese living in the "liberated" areas under control of the Party; and binh van ("action among the troops"), operations calculated to disrupt the Government armed forces and civil services. ${ }^{5}$

The majority of this chapter will be devoted to a discussion of dich van, because in the villages of Dinh Tuong that had been penetrated by the Party but were not yet under its control, the inhabitants were considered enemies until a later stage in revolutionary development was reached, at which time the propaganda section devoted much of its efforts to dan van and binh van.

The general objective of dich van was, according to a Party document, to cause "the masses to become enlightened about their oppressed and exploited interests, [making] them clearly realize why and because of what their life is so miserable." The document then directed cadre in propaganda sections to

make them clearly understand [that] the Party's line, policy, [and] stand aimed at defending the masses' interests, opposing oppression and exploitation, so that they have confidence in and voluntarily act after the Party's line. ${ }^{6}$

Application of this policy took the form of a four-step process, which was recorded in the notebook of a cadre in a propaganda section:

1. Increase feelings of discontent on the part of the people before trying to mobilize their patriotic feelings.

2. Explain to the people the efforts being made by the enemy to divide us from the population.

3. Educate the people about our struggle in South Viet-Nam.

4. Stress the importance of our Front for the Liberation of South Viet-Nam (which already has legal

5. Douglas Pike, Viet Cong, p. 86.

6. VCD 75, p. 11. 
status in Viet-Nam and throughout the world). Also, educate the people about our Party's basic policies, about North Viet-Nam, about socialism, and other world news. ${ }^{7}$

Before initiation of the disruptive process, the security section gathered information about the political orientation of all families in the village. In some cases, cadres from district or higher security elements came to the village to help collect information and process it into intelligence, which was published in the form of family lists. These lists classified families according to their estimated potential for causing problems for the Party: ${ }^{8}$

Category A. Families who would actively support the Party in the village. This group consisted of ban co nong ("very poor farmers"), ban nong ("poor farmers"), trung nong ("middle farmers"), and those families with relatives serving in the Party.

Category B. Families with no connection with either the Party or the South Vietnamese Government. Also included in this group were those middle farmers who were not placed in Category A, phu nong ("rich farmers") who had no adverse information in their dossiers, and a very few dia chu ("landlords").

Category C. Families in this category consisted mainly of the bulk of the landlords, all Catholics, and families of any class who had relatives serving the South Vietnamese Government.

The Party used these lists to determine its treatment of the village population and the orchestration of its propaganda efforts. The Party, according to a former member, adopted a "lenient" attitude toward the "good elements," Category A; it tried to "re-educate" Category B families; and "constantly watched over the C Category." 9

No matter how poor or remote the village in Dinh Tuong, the South Vietnamese Government enjoyed at the outset what Thornton has described as an "inertial relationship" between

7. Quoted in Malcolm W. Browne, The New Face of War, pp. 138-39.
8. DT-108, p. 15.
9. DT-86, p. 5 . 
itself and the village.$^{10}$ Simply put, the village was to respond to the demands of the Government, no matter how weak the presence, because there were no other authoritarian demands from other directions. This relationship, undisturbed, integrated the Government and the villages into a single social structure. It was only when the Party applied stress that the fragility of the bonds became apparent.

The Party's intensified campaign to break those bonds began on a nationwide scale in mid-1957. ${ }^{11}$ By March 1958, Bernard Fall noted that more than 400 village officials had been assassinated by the Party. ${ }^{12}$ In Dinh Tuong Province, the first mention of systematic destruction of Government presence appeared in early 1959, when the Party embarked on the assassination of schoolteachers. This campaign, which was concentrated in the key Mekong Delta provinces of Long An, Kien Hoa, and Dinh Tuong, contributed to the subsequent lack of schooling for nearly 30,000 children-children who, to the advantage of the Party, were no longer in contact with the Government of South Viet-Nam. ${ }^{13}$

The first wave of Party terror was called the Destruction of the Oppression and marked the partial emergence of the Dang Lao Dong from its clandestine organizational phase. Most knowledgeable sources agree that the Destruction of the Oppression moved into full swing in late 1959 or early 1960 in Dinh Tuong. ${ }^{14}$ The Party's intention to create disorientation and isolation was revealed by the statement of a former Party member and participant in the Destruction of the Oppression:

Our purpose was not only to eliminate those who could be harmful to the movement but also with a

10. Thornton, "Terror as a Weapon," 74.

11. Bernard B. Fall, The Two Viet-Nams, p. 359.

12. Bernard B. Fall, "Viet Nam In The Balance," Foreign Affairs, 44, 1 (October 1966), 12.

13. Fall, Two Viet-Nams, p. 360.

14. DT-86, p. 2; DT-99, p. 2; Rand Corporation and MACV J-2, File No. DT-84 (I), Studies of the National Liberation Front of South Vietnam, p. 2 (Cited hereafter as DT-84); Rand Corporation and MACV J-2, File No. DT-88 (I), Studies of the National Liberation Front of South Vietnam, p. 1 (Cited hereafter as DT-88). 
view toward making the people afraid and to prevent them from cooperating with the government. ${ }^{15}$

The manner in which the Destruction of the Oppression was carried out varied from village to village, depending on the estimates of the situations arrived at previously by the security and propaganda sections. In Chau Thanh District, the seat of the provincial capital of My Tho, the Party arose suddenly in Thanh Phu village. One farmer recalled:

In 1959, many leaflets and posters were spread in my hamlet. They were leaflets and posters made by the [Party]. One night, the Party's followers came into my village, all of a sudden, to carry out the "destruction of the oppression." They arrested the chairman of the [Government] National Revolutionary Movement, led him to the ricefield, shot and killed him.

After that, they disseminated leaflets which accounted for this killing and mentioned the charges against the dead.... The villagers were very afraid. The [Party's] followers were then led by a man, named Dong, who came from my village. He was a poor peasant (ban nong) and several months before, he had left the village for an unknown place. ${ }^{16}$

The unveiling of the Destruction of the Oppression was abrupt in the district of Long Dinh, west of Chau Thanh. There, three former members of the Viet Minh had secretly formed a Party cell. On orders from the Party, the three killed their village leaders and imprisoned a few of the lesser Government officials. The remaining village leaders in the area immediately resigned their positions. ${ }^{17}$ In some cases, widespread bloodshed was not necessary. In Hoa Dinh, a large village in eastern Dinh Tuong, the Party executed four men in one swift move and took over the village. No non-Party member dared to take a position of responsibility in the village following this episode. ${ }^{18}$

In Cai Lay District, which had been a Party redoubt since the early $1940^{\circ}$ 's, intimidation also worked well. Party cadre organized a mass meeting of one village's inhabitants, explained the Party's platforms, then denounced the reac-
15. DT-99, p. 2.
16. DT-88, pp. 1-2.
17. DT-86, p. 2.
18. DT-84, p. 2. 
tionary activities of the village chief. The participants in the meeting were asked if they felt that the "sinful" official should be executed or be shown "mercy." The villagers, wisely not questioning the guilt or innocence of the culprit, "suggested that he be pardoned the first time." The official was so shaken by this experience that he left the village immediately. ${ }^{19}$

At other times, in different circumstances, the terror of the Destruction of the Oppression, which apologists for the Party have often excused on the grounds that it was "selective," could take on the appearance of a charnel house. In a Cai Lay village that had changed hands between the Front and the South Vietnamese Government four times in as many years, twenty persons, including women, were accused of being Government spies:

They all had their heads cut off and their bodies were thrown in the street. On them were pinned the charges written on a piece of paper. Government cadres were terrorized ... and slow[ed] down their activities. ${ }^{20}$

The scene of another particularly bestial execution was visited by Malcolm Browne. The hamlet chief in this instance had been tied to a stake in the middle of the market place in full view of the assembled villagers. The man was slowly disemboweled, his child decapitated, and his pregnant wife then tied to the same stake and similarly disemboweled.21

Terror was most effective when it appeared to the villager to be only partially selective. The Party at times accused and then executed or humiliated certain persons for their pro-Government activities when even a cursory examination would have revealed the charges to be baseless. Had the Party been consistently discriminatory, eliminating only those persons widely known to be class enemies, then the terror would have become highly predictable and incapable of creating the desired level of anxiety response among the

19. Rand Corporation and MACV J-2, File No. DT-58 (II), Studies of the National Liberation Front of South Vietnam, Pp. 2-3. Cited hereafter as DT-58.

20. W. P. Davison, Some Observations on Viet Cong Operations in the Villages, p. 25.

21. Browne, New Face of War, p. 103. 
villagers. The reaction of the inhabitants of Tam Hiep village in Chau Thanh is an example:

The Tam Hiep villagers were very dissatisfied with the Front's murders. Only the cadres' families were relieved when Hai Khai, a GVN security agent was killed.

The people thought that, except for Hai Khai, the others were innocent. ... Therefore the Tam Hiep villagers thought the deceased were killed out of vengeance. ... These killings made the villagers scared and they obeyed the Front to save their lives. The same frame of mind pushed the youths to join the guerrillas. ${ }^{22}$

The Party did find that sometimes terror could be pushed too far. In another Chau Thanh village, after the public execution of nine persons, some of the village youths sought safety by volunteering to join the Front armed forces. An unknown number of other youths, for the same reason, sought haven by enlisting in the Army of South Viet-Nam, which canceled out the immediate gains of the Front armed forces. ${ }^{23}$

It is understandable that replacements for these village leaders would be hard to come by-even the most dedicated men who would not hesitate to sacrifice their own lives would be reluctant to expose their families to such treatment. Even so, some men, who for various reasons were willing to assume the responsibility of village and hamlet chiefs, did come forward, but they were forced to reach accommodations in order to survive and thus destroyed their usefulness to the South Vietnamese Government. The author, who traveled widely in the villages of the upper Mekong Delta in 19641965 , found it unusual to locate a remote village in which South Vietnamese Government officials lived in their homes at night. The village leaders generally stayed in the district town, if one was nearby, or in a military outpost and visited their villages only during the day with an armed escort. This situation limited the exposure of the Government to the villagers and at the same time was a very persuasive argument to the villagers that the Government leaders lacked the ability to cope with the problems created by the Party.

22. DT-59, p. 7 .

23. Ibid., p. 6. 
The killings in Dinh Tuong were not spontaneous; the village Civil Affairs Committee was not given carte blanche to assassinate at will. Party documents and testimony of Party members indicate that these killings were carefully planned and were influenced by prevailing local conditions. The elimination of South Vietnamese Government officials was not the result of a peasant uprising, as suggested by Eqbal Ahmad, Bernard Fall, and others; ${ }^{24}$ assassination was a political instrument wielded only by the Party and, like all instruments, completely subordinate to Party political policies. The rather simplistic claims of the Jacquerie proponents are substantially discredited by the testimony of the chief of the military affairs section of Xuan Dong village, Cho Gao District:

In principle, the [Party] tried to kill any GVN official who enjoyed the people's sympathy and left the bad officials unharmed in order to wage propaganda and to sow hatred against the [Government]. ${ }^{25}$

This is not to say that only popular officials were eliminated by the Destruction of the Oppression. It was the author's observation in South Viet-Nam that the Party's executions of popular officials were done in the fashion of an "impersonal" attack on the symbol of Government presence. When executing an unpopular leader, the Party usually made a great show of punishing him for his personal "crimes against the people." ${ }^{26}$ In most cases, the manner of execution was different also: the popular official was often eliminated without fanfare or witnesses; ${ }^{27}$ the unpopular official was killed before the village at large.

In the "contested" areas the village Civil Affairs Committee received the greatest degree of latitude in executing its enemies and possessed the "absolute right" to kill those who were overt agents of the Government, such as police,

24. Eqbal Ahmad, "Revolutionary War and Counterinsurgency," in National Liberation: Revolution in the Third World, ed. by Norman Miller and Roderick Aya, p. 16o; Fall, "Viet Nam In The Balance," 12.

25. DT-79, p. 4.

26. Vietnamese Communist Document 27, Death notice.

27. Rand Corporation and MACV J-2, File No. DT-105 (II), Studies of the National Liberation Front of South Vietnam, p. 1. 


\section{THE VILLAGE WAR}

members of village councils, and hamlet and village chiefs. A chillingly nonchalant statement by one Party member described the procedure to be followed by the security section when it apprehended such persons:

In the case of these people, there is no need for the Security Section to obtain instruction in advance. When they have the opportunity, they just kill them and then report back later on. ${ }^{28}$

Party authority for summary execution in the "liberated" areas was retained at the district Party level, reflecting the confidence of the Dang Lao Dong that other means could be used to control the population. In those portions of the "liberated" areas under the strongest control of the Party, the province authorities assumed the responsibility and authority for executions. Because, by definition, the "liberated" zones had largely been "cleansed" of Government presence and the people in them had been properly indoctrinated, executions were minimal, and "re-education" was the first resort for elimination of wrong tendencies. ${ }^{29}$

The Destruction of the Oppression was initiated at different times throughout South Viet-Nam's many rural villages. The cumulative total of assassinations of village officials, schoolteachers, public-health workers, and other civil servants indicates that there was a definite "cresting" of killings in $1963:^{30}$

$\begin{array}{lc}\text { Year } & \text { Assassinations } \\ 1957-1960 & 1,700 \\ 1961 & 1,300 \\ 1962 & 1,700 \\ 1963 & 2,000 \\ 1964 & 500\end{array}$

The exact reasons for the sharp drop between 1963 and 1964 are open to conjecture, but one of two factors, or a combination of both, offers a plausible explanation: first, by 1964, the Destruction of the Oppression had successfully eliminated Government officials from areas the Party had earlier penetrated; ${ }^{31}$ second, the South Vietnamese officials in the rural

28. DT-108, p. 79.

29. DT-86, p. 13.

30. Extracted from Pike, Viet Cong, p. 102.

31. Ibid., p. 248. 
areas were no longer exposing themselves to the Party cadre for elimination-and it should be added that neither were the officials exposing the population of the rural villages to the Government.

Whatever the reason for the apparent drop in the number of deaths, the over-all number of political assassinations, when compared to the total number of deaths from violence of all sorts, represented an almost insignificant fraction. However, in view of what the deaths by the Destruction of the Oppression meant in terms of lost low-level leadership, the number assumes a frightening proportion. The elimination of village leaders by the Party cut off the South Vietnamese Government from many of its rural villages. For a nation in which more than 80 per cent of the population was rural, the deaths put the Government in the position of "legislating in a void." ${ }^{32}$ Gone was the Government's tenuous linkage to the peasantry-the means by which the young Vietnamese Government could have implemented meaningful political and economic programs. The Destruction of the Oppression vividly made the villagers believe that the South Vietnamese Government had neither the ability nor the will to protect its own village officials, that it could not offer support for the population in return for that population's loyalty.

The Destruction of the Oppression was complemented by the Reduction of Prestige, a "special form of repression usually ... reserved for local government officials whom the Viet Cong wish to debase before their fellow villagers." ${ }^{38}$ A village leader marked for Reduction of Prestige was often kidnapped, isolated, and "re-educated" in a secret location. Usually, the "re-education" succeeded in intimidating the victim to the extent that he was ready to admit to specified crimes in order to escape with life and limb intact, whereupon he was brought before the assembled villagers, his crimes against the people were enumerated, and he was forced to recant. In a society that prized dignity and virtue, the Reduction of Prestige caused serious psychic shock. A former Government official in the district of Cai Be described his kidnapping and "re-education" and their effects this way:

32. Fall, Two Viet-Nams, p. 359.

33. Stephen T. Hosmer, Viet Cong Repression and Its Implications for the Future, p. 60. 


\section{THE VILLAGE WAR}

They treated me rather well and I was not beaten up by them. I was, however, blindfolded and tied up all the time. On the sixth day, they led me back to My Trinh and I had to stand up in front of the villagers gathered in meeting to acknowledge my errors and apologize to them. It was only then that they took off the blindfold. ... I was released thereafter because the [Party] judged that I had not yet [been] a party to any bloody affairs. This was a reduction-of-prestige campaign aimed at me and I felt very ashamed when, from the villagers' ranks, some people came out to curse me.

My emotional life was then very hard. I felt wretched. None of the villagers were [sic] willing to talk to me except a few of my closest relatives. My wife had to undergo bitter criticism from the villagers for my past services to the GVN [Government of Viet-Nam]. ${ }^{34}$

A like pattern was followed in Long Dinh. When the Party "rose up" in Vinh Kim village, the village officials fled. The Party promised them amnesty and asked their families to call them back. Upon their return, the Dang Lao Dong set up a "people's court" and subjected the men to a reduction of prestige. The Party agreed to be lenient toward the defendants and released them. "From then on," a witness related, the Party "had control of the village." 35

The advantage of Reduction of Prestige over Destruction of Oppression was that the former avoided stirring up unnecessary hostility against the Party and at the same time gave the Dang Lao Dong an undeserved reputation for mercy. If the humiliated, publicly degraded official remained in his home village, as many did, so much the better for the Party, because his presence served continually to warn others of the consequences of opposing the Party. The nature of the Reduction of Prestige prevented a computation of the number of persons so treated. Stephen Hosmer lists 36,800 kidnappings of village-level officials from $195^{8}$ to 1965 , and it is likely that some of these kidnappings were the initial stage of Reduction of Prestige. ${ }^{36}$

34. Rand Corporation and MACV J-2, File No. DT-64 (I), Studies of the National Liberation Front of South Vietnam, pp. $5-6$. Cited hereafter as DT-64.

35. DT-99, p. 2.

36. Hosmer, Viet Cong Repression, p. 42. 


\section{PREPARATION OF THE PEOPLE}

Terror directed at what the Party called the "AmericanDiem clique" was also used to elicit a powerful reaction from civilians in the "contested" and "liberated" areas-a case of utilizing binh van to buttress the dich van and dan van programs. An example of such an operation was the bombing of the United States Embassy on a workday in early 1965. Only two Americans were killed, whereas many noninvolved Vietnamese casualties resulted, but by striking at the very symbol of U.S. presence in the heart of Saigon, the Party had once again demonstrated that it was able to reach anyone, anywhere, and at any time. The U.S. Mission, in an attempt to arouse indignation among the Vietnamese, hurriedly printed large posters describing the attack, complete with detailed photographs of the damage. The posters were then distributed throughout the nation, which served to reinforce the Party propaganda effort at the expense of the U.S. taxpayer ${ }^{37}$ The reaction in the countryside was predictablethe Vietnamese peasants reasoned that if the Party could seriously threaten the United States ambassador, a defenseless peasant would not present a difficult problem.

Not all villages that succumbed to the Dang Lao Dong in Dinh Tuong did so because of the Party's efforts alone. In at least one documented case, the Party was able to take over a village after incompetent Government officials at the district level had inexcusably blundered. Hau My village of Cai Be District had twenty persons assassinated by the Party on July 20, 1960. The Council of Notables arrested some Party supporters but was unable to capture the Party cadre who were directing the Destruction of the Oppression from outside the village. The $\mathrm{Cai} \mathrm{Be}$ district chief ignored the recommendations of the village council and, using faulty information of his own, began a series of arrests that resulted in imprisonment of innocent villagers. The villagers suspected that the village council had recommended the arrests, which had not been the case, and the council members, having gained the animosity of their neighbors, rightly felt that they were not being supported adequately by their superiors.

Subsequently, the district chief disregarded the coun-

37. The author was a member of the U.S. agency that published the poster and was a witness to the immediate aftereffects. 
cil's suggestions about the peasants who should receive agricultural loans. After having painstakingly made a list of the deserving and industrious farmers who should receive grants or loans, the village council saw the district chief eliminate most of them because he suspected, for no reason, that the recommended recipients were Party sympathizers. Loans went instead to those who were trung nong ("middle farmers") and above, not to the great numbers of poor and very poor farmers who had the greatest need. Again, the village council faced resentment and loss of prestige. Meanwhile, the propagandists of the Party were hard at work, scoring points on the issues created for them by the stupid vagaries of the district chief. As one member of the village council who was later to become a supporter of the Party recalled, the actions of the district authorities caused the council members

to think that the government also suspected its own servants. For all these reasons, we became discouraged and took up a passive attitude. From then on, we only did what we were told to do, without taking any initiatives or making suggestions. ${ }^{38}$

The district chief then administered the fatal blow to Government control of $\mathrm{Hau} \mathrm{My}$. The village chief, Mr. Ba Dec, was a staunch Catholic, an anti-Communist, and a man respected by the villagers in spite of the blunders of the district chief. Relying again on faulty intelligence and plagued by unfounded suspicions about the loyalty of the village council, the district chief had Ba Dec arrested and imprisoned for more than a year by the district authorities. He was later released due to lack of evidence, but he was understandably discouraged and did not return to Hau My. The village went under Party control at the time of his arrest in 1961 and was still under its control as of $1965^{39}$

\section{Land Reform as a Tactic of the Party}

The highly visible manifestations of mutilated bodies of leaders who had been killed by the Party gave rise to the invalid but oft-quoted axiom that it had only to destroy while the South Vietnamese Government had to build, as well as
38. DT-64, p. 3.
39. Ibid., pp. $2-8$. 
PREPARATION OF THE PEOPLE

fight. ${ }^{40}$ The Party recognized that destruction alone does not suffice to bring about new societies, and this recognition is illustrated by the following excerpt from a critical study of the Party take-over of "XB" village:

Better to meet the enemy, which remained strong in the village, the Party began the elimination of influence of the village notables and local security agents. However, it failed to follow this with the development of a mass base. The cadres thought that efforts to end the authority of the village leaders alone would be enough. ${ }^{41}$

The first objective of the Party after having eliminated competition within the village was to develop policies more beneficial to the middle, poor, and very poor peasants, so that when the time came for combat, members of these classes would remain passive, withholding their support from the South Vietnamese Government. ${ }^{42}$ The tactical policy of the Party was land reform.

"Land to the Landless," however stirring the cry, was a slogan representing not the altruistic ends of the Party, but the means by which the Dang Lao Dong gained dominance over the rural population. That land reform was more a political than an economic strategy-that the Party only used the land-hungry South Vietnamese peasant as an instrument to further its long-range goal of subjugation-was evident in the " $\mathrm{XB}$ " village report:

In its political and armed struggle, in its administration of the rural area, and in other revolutionary tasks, the Party knew well how to make use of the farmers' interest in land [Emphasis added.]. On it we built a mass movement. And for that reason the revolutionary movement made great progress.

Again, the same document stated:

The main interest of the farmer ... is in land. Before, during and after the elimination of our enemy's influence, the Party ... always used the subject of land

40. W. W. Rostow, "Guerrilla Warfare in Underdeveloped Areas," Marine Corps Gazette (January, 1962), 48-49.

41. VCD 2, p. 40.

42. Jeffrey Race, "How They Won," Asian Survey, 10, 8 (August, 1970), 633. 
as a means of propagandizing the masses [Emphasis added.]. ${ }^{43}$

During the war against the French, the Viet Minh in Dinh Tuong had used the "land-to-the-tiller" theme with success. A long-time Party member, one who had regrouped to North Viet-Nam and then returned, recalled that he had entered the Viet Minh not because of the appeal of Marxism, but because of the organization's land policies:

The cadre propagandized that the youths should fight the enemy and reclaim the land. This propaganda made me very enthusiastic because I wanted to kill the enemy and I wanted to have the land. I knew very well how miserable the life of a landless peasant was. ${ }^{44}$

Referring to his home village in Dinh Tuong, the source continued:

The Viet Minh came through on their promises. They actually took the land from the landlords and distributed it among their followers. Their propaganda stuck [sic] a responsive chord in me because I hated the French, who had arrested my father, and who were in league with the landlords that had oppressed and beaten me. I entirely agreed with the Viet Minh propaganda, and followed them enthusiastically. ${ }^{45}$

Later, in Dinh Tuong and elsewhere in the Mekong Delta following the French defeat, the land titles still remained in the hands of the landlords. The ineffectual efforts of the Diem Government in redistribution of land resulted in landlords reclaiming lands previously distributed by the Viet Minh. Bernard Fall observed that in some areas the landlords accompanied the South Vietnamese Army back into the Viet Minh zones and, behind the protection afforded by the new Government, reduced the landholding peasants back to the status of tenant farmers. ${ }^{46}$ Such a situation was a blessing to the Party. As the " $\mathrm{XB}$ " village report of this period stated, the Dang Lao Dong

43. VCD 2, p. 42.

44. DT-101, p. 3.

45. Ibid., p. 4 .

46. Fall, "Viet Nam In The Balance," 5. 
awoke the people to the fact that if the AmericanDiem clique succeeded in permanently maintaining the organization of the village notables and security [agents], soon ... the cruel landlord and others would return to the village to seize land and collect back rent. For that reason, we said, the farmers must eliminate the influence of the village notables and sweep away the security agents. ${ }^{47}$

The report described how the propaganda section carried out the deception in this campaign, even pausing parenthetically to laugh up their sleeves:

At the same time we sought to win the sympathy of the families of the village notables (while we were urging the masses to rise up and eliminate the influence of the notables). It was a good method..$^{48}$

The Party policy regarding land redistribution was in keeping with the flexibility called for and exhibited by Truong Chinh and Ho Chi Minh in the 1950's in North Viet-Nam: local cadres in Dinh Tuong were given leeway to decide the extent of land appropriation and redistribution according to the conditions prevailing in their villages. In some areas such as Xuan Dong village, the Party merely "mobilized" the landlords, persuading them to donate to the Front the paddy (unhusked rice) that their tenants had paid in kind for land rent. ${ }^{49}$ Thus the Party set itself up as a silent partner of the landlords-a partnership that was profitable only to the Party but offered the landlords the hope that they might be able to hold onto their lands at least until the Party was somehow defeated. In other villages of Dinh Tuong where the Party redistributed land, such redistribution generally took place throughout the time period 1961 to 1964 , with most of the sources reporting the greatest activity between 1961 and 1962. The Party made subsequent adjustments of land holdings whenever it deemed necessary. For instance, one respondent stated that the Party had redistributed land after taking over his village in 1961 . By 1965 , after many farmers had left the village for the security of the larger towns, the Party parceled out the land that was lying fallow to those who remained..$^{50}$

47. VCD 2, p. 41.

49. DT-79, p. 24.
48. Ibid.

5o. DT-84, p. 1. 
This redistribution of land by the Party did not create new landowners. The Party never issued deeds of ownership in the redistribution process. ${ }^{51}$ Indeed, one Party directive was quite explicit on the point of land ownership:

Maintaining land ownership means to maintain it for all the peasants so that they could have land to do cultivation and production ... and have peace of mind to carry on [the] struggle against U.S.-Diem; that does not mean at all to grant land to individuals to make it personal property. ${ }^{\mathbf{5 2}}$

The reliance upon land as a tactic to propagandize the peasantry did cause problems for the Party; the peasants lost interest in revolutionary activities once their craving for land was satisfied, and as a Party report indicated, the Party found it difficult to inculcate further motivation:

Though the Party correctly based its action on the people's interests-especially with respect to landand persuaded them to join the mass movement, it did not know how to profit from the opportunity to teach the people that their rights and interests must be subordinated to the national interests ... or that they must focus all their resentment on, and fight against the U.S.-Diem clique. Consequently once the people are satisfied about land, the movement degenerates. ${ }^{53}$

\section{Peasant Resistance}

The Party's strategic task, that of creating personal isolation and disorientation, met with the least success among the peasants who were of the Catholic and Cao Dai faiths. ${ }^{54}$ The Catholics, in particular, exhibited a resistance to disorientation in much the same manner described by Emile Durk-

51. William Bredo, "Agrarian Reform in Vietnam: Vietcong and Government of Vietnam Strategies in Conflict," Asian Survey, 10, 8 (August, 1970), 747.

52. Vietnamese Communist Document 296, "Resolution: Some Land Tasks for the Year 1962," p. 3.

53. VCD 2, p. 60.

54. The Cao Dai, a syncretic religion established in 1925 , is organizationally similar to the Roman Catholic Church, complete with priests, nuns, bishops, and a pope presiding from a Holy See in Tay Ninh Province, northwest of Saigon. 


\section{PREPARATION OF THE PEOPLE}

heim in his classic work Suicide, and for much the same reason. ${ }^{55}$ The inherent difficulty of the Party's dich van campaigns among Catholics and in areas where there were many members of the Cao Dai religious sect was the ability of these people to cope with social disorientation by drawing on not only the support of their families but also the strength derived from the larger church organization. The Cao Dai and Catholic communities possessed in their religious vertical hierarchies an extrafamilial and extravillage means of support that were not available to either the Buddhists or the Confucianists. To use Thornton's definition, the Catholic and Cao Dai keystones were not familial or local but national in scope. To create the desired level of disorientation among the individuals in these groups, the Dang Lao Dong would have to destroy the Catholic and Cao Dai national organizations, a task that so far it has not been able to do in South Viet-Nam.

In predominantly Catholic villages, the Party consistently encountered problems in establishing clandestine cells and in drumming up support for the elimination of village offcials, most of whom were Catholics. ${ }^{56}$ The Party policy regarding assassination of these officials was particularly stringent. A 1962 Party document warned subordinate security and propaganda sections that "in a strongly religious ... zone, the arrest and punishment of intelligence agents and spies should be made with great care. ${ }^{57}$ Another document cautioned that "where there are refugees from the North ... or Catholics, we must be specially careful." ${ }^{8}$ Even in a "contested" area where the village Civil Affairs Committee usually could give approval to its security section to eliminate certain officials, it had to request permission of the district Party Committee to attack Catholics. In the areas where the district committee retained authority for executions of all sorts, the province Party Committee determined the fate of

55. Emile Durkheim, Suicide, trans. by John A. Spaulding and George Simpson, p. 209.

56. DT-79, p. 4 .

57. Vietnamese Communist Document 7, untitled directive concerning counterespionage activities of the Dang Lao Dong, p. 10.

58. Ibid.; Vietnamese Communist Document 15, Dang Lao Dong directive, p. 6. 
Catholics..$^{59}$ Just as with popular village chiefs, Catholics earmarked for elimination were generally taken away from their villages and were not slain publicly in their home villages. ${ }^{60}$ The Dang Lao Dong did not confiscate lands belonging to the Catholic churches, although it did force them to reduce rents charged to the peasants. ${ }^{61}$

\section{The Dilemma of the Peasant}

The elimination of the traditional sources of leadership by the Destruction of the Oppression and Reduction of Prestige campaigns resulted in a drastic alteration of the power relationship within the village. If "power" is defined as the ability to influence another's actions in a manner beneficial to one's interests, the power relationship between the Dang Lao Dong and the Government of South Viet-Nam would depend on the comparative effectiveness of those two opponents in the competition for supremacy over the village population. ${ }^{62}$ Whereas the Government had the big battalions and the Party had only a few armed cadre in the village, the cadre were in the village, day in, day out. The Government battalions were able to influence the villagers only while operating in the village, which amounted to a few hours each month.

If the cadre were matched against the regular Government forces in pitched battle, the Party elements would have been destroyed by the South Vietnamese battalions, which clearly possessed the necessary force. The Party, however, refused to pit itself against the Government in this way, choosing instead to direct itself against the village and its traditional institutions. Although the Party's force was weaker than that of the Government, it was a consistent pressure on the village population; the Government's force and influence was sporadic and of short duration, and it was all the more ineffective because it was directed not toward the population, but at the Party. In the long run, the Party's lesser force, continually applied, was better able to influence the villager than was the South Vietnamese Government.

59. DT-79, p. 9.

6o. Rand Corporation and MACV J-2, File No. DT-85 (I), Studies of the National Liberation Front of South Vietnam, p. 9.

61. VCD 737, p. 14 .

62. Race, "How They Won," 629-30. 


\section{PREPARATION OF THE PEOPLE}

The peasant, fully aware of which side was the more powerful in his village, did not have recourse to highly trained state police or militia. Had a peasant decided to go to the district capital to report the happenings, the Party would take reprisals against his family. If he did take such a drastic step, he had no guarantee that the authorities would act, since the Government was facing similar problems in many other villages and was required to keep open the lines of communication between the larger towns and to ensure the security of fixed installations. In the end, the peasant's alternatives were narrowed to two: remain with his land in his native village, which probably had been the land of his ancestors, or become a rootless refugee. 
The masses, enlightened by propaganda yet left scattered, do not constitute a force and are not able to cope with the enemies. That is why, side by side with the masses propaganda, one should think of organizing the masses, gathering them into numerous and strong forces to oppose the enemies.

-Dang Lao Dong Directive,

Vietnamese Communist Document 75

\section{EXPANSION OF}

\section{PARTY CONTROL}

In the expansion phase of the Dang Lao Dong's operations in the Dinh Tuong villages, the peasants were drawn into and integrated in an intricate organizational structure created by the Party. During this phase, "the two linchpins of the revolution" 1 were forged: the mobilization of the village population in preparation for military and paramilitary operations and the implementation of Party taxation. The mobilization of the population and the concurrent growth of the Dang Lao Dong apparat led to increased political power through implementation of taxation policies.

\section{The Mass Organizations}

To the Dang Lao Dong, gathering the masses meant establishing mass organizations. In Communist parlance, a mass organization is one controlled by the Party and composed primarily of persons who are not Party members and who do not realize the extent or degree of Party control. Once established in South Viet-Nam, the mass organizations of the

1. DT-101, p. 34. 


\section{EXPANSIONOF CONTROL}

Dang Lao Dong coalesced and formed an entity that represented itself as the National Front for the Liberation of South Viet-Nam or, simply, the National Liberation Front.

By its very nature an elitist organization, the Dang Lao Dong's numbers were small in comparison to the masses it wished to control. The answer was not to expand the membership of the Party to encompass the masses, for such a solution would result in degradation of Party internal discipline. "Che" Guevara, recognizing that Communist parties single-handedly could not reach all the masses, stated that one of the first tasks of the revolutionary in a rural base area should be to establish mass organizations in order to win over the masses. ${ }^{2}$ C. A. Hathaway, in an article entitled "On the Use of 'Transmission Belts' in Our Struggle for the Masses," provided a clear rationale for the mass organization and its uses to the Party. The mass organizations, Hathaway wrote, could be

made to reach many thousands of workers not yet prepared for Party membership. Through these organizations, led by well-functioning fractions, the Party must necessarily find its best training and recruiting ground. They are the medium through which the Party, on the one hand, guides and directs the workers in their struggles and, on the other hand, keeps itself informed on the mood of the masses, the correctness of party slogans. ${ }^{3}$

In addition to acting as transmitters of Party propaganda to the masses and as personnel reservoirs from which future Party members were recruited, the mass organizations in South Viet-Nam concealed the dominant role of the Dang Lao Dong in the revolutionary struggle. The use of the mass organizations in this way was the subject of an internal study document for Dang Lao Dong members:

If the mass organizations develop, if the mass activities are strengthened, the Party's organization and secret

2. Ernesto "Che" Guevara, Guerrilla Warfare, pp. 56-57.

3. C. A. Hathaway, "On the Use of 'Transmission Belts' in Our Struggle for the Masses," quoted in Michael Charles Conley, The Communist Insurgent Infrastructure in South Vietnam: A Study of Organization and Strategy, U.S. Department of the Army Pamphlet No. 550-106, p. 224. 
activities will be rendered easier and more carefully concealed. ${ }^{4}$

The mass organizations enabled the Dang Lao Dong to group large numbers of persons, who were then indoctrinated in ways that furthered the aims of the Party. ${ }^{5}$ The over-all goal of the Dang Lao Dong in relation to the mass organizations was, as pointed out by Douglas Pike, to "mold the leadership of the individual organizations together into an administrative National Liberation Front village liberation committee," which would be overtly or covertly under Party control. ${ }^{6}$

The Indochinese Communist Party had created mass organizations in the abortive Nghe An-Ha Tinh soviets. These mass organizations were structured to encompass most of the population. The primary organizations in this early period of Party history were the Peasants' Association, the Youth Organization, and the Women's Association. Before the soviets were crushed, these organizations had supplanted the age-old Councils of Notables in the Party's base areas. ${ }^{7}$ Similarly, the mass organizations of the Dang Lao Dong in Dinh Tuong were established on the basis of occupation, age, or sex. There were three major mass organizations: the Farmers' Liberation Association (FLA), the Women's Liberation Association (WLA), and the Youth Liberation Association (YLA).

The Farmers' Liberation Association. The preamble to the regulations of the Farmers' Liberation Association asserts that the farmers "who create ricefields and gardens ... are deprived of ... rightful possession since they fall in the imperialist and feudalist grasp." Outlining the grievances of the farmer in the manner of the U.S. Declaration of Independence, only the FLA regulations clearly specified the relationships of the FLA to the Party, stating that the as-

4. VCD 75, p. 19.

5. Vietnamese Communist Document 50, Regulations governing Dang Lao Dong in South Viet-Nam, p. 18. Cited hereafter as VCD 50.

6. Douglas Pike, Viet Cong, p. 115.

7. John T. McAlister, Jr., Vietnam: The Origins of Revolution, p. 88. 


\section{EXPANSIONOFCONTROL}

sociation was "under the leadership of the workers and the vanguard revolutionary party, that is the Indochinese Communist Party and at present the Viet Nam Labor Party [Dang Lao Dong]." 8 The regulations again referred to the leadership role of the Dang Lao Dong within the National Liberation Front:

The Farmer Association also advocates a close union with other social classes and revolutionary forces affliated to the National Liberation Front of South Viet-Nam ... under the leadership of the Viet Nam Labor Party. ${ }^{9}$

The Farmers' Liberation Association was open to the lower three classes of farmers ("middle," trung nong; "poor," ban nong; "very poor," ban co nong), regardless of religion or sex, provided the members were at least 16 years of age. ${ }^{10}$ Party directives called for attaining a goal of membership of $5^{\circ}$ per cent of the farmers in the "liberated" areas, $3^{\circ}$ per cent in the "temporarily liberated" areas, and 20 per cent in areas controlled by the South Vietnamese Government. ${ }^{11}$ To be admitted to the FLA, the prospective members had to agree to follow the internal regulations of the association and to volunteer to "fight against My-Diem" (Americans and Ngo Dinh Diem). Other responsibilities of membership were to gain friends for the FLA, ever increasing the numbers of acquaintances, to preserve association secrets, and to participate in meetings. ${ }^{12}$ At a time when VN\$20 (about U.S. $\$ 0.15$ ) could purchase two meals, the monthly dues of the FLA in Dinh Tuong Province were VN\$2 per month. ${ }^{13}$

The organization of the Farmers' Liberation Association closely paralleled that of the Dang Lao Dong. New members were inducted into cells consisting of three to five persons, one of whom was the cell leader. When three cells were formed, an executive committee was established. From the

8. Conley, Communist Insurgent Infrastructure, p. 287.

9. Ibid., p. 288.

11. Pike, Viet Cong, p. 169.

12. Conley, Communist Insurgent Infrastructure, p. 289.

13. Rand Corporation and MACV J-2, File No. DT-63 (III), Studies of the National Liberation Front of South Vietnam, p. 15. Cited hereafter as DT-63. 
executive committee a permanent committee of three persons was appointed to take care of the daily affairs of the association. When the association expanded to seven or more cells ( 21 to 35 persons), the executive committee appointed a cadre section, which became an operational department responsible for supervising the implementation of the guidance passed on by the permanent committee. ${ }^{14}$

In Dinh Tuong, the Farmers' Liberation Association also established the hoi tro tang, a mutual-aid organization open to members of the FLA. The function of the hoi tro tang was to assist in funeral arrangements. Upon the death of any member, each of the survivors contributed one piaster toward burial expenses and, at the direction of the leader of the funeral association, assumed some of the responsibility for burying the dead and conducting the funeral..$^{15}$ The effect of the hoi tro tang was to transfer such duties from the head of the family to a mass organization's special-interest group, which was controlled by the Party. Thus, the villager depended no longer upon his family but upon the Party for the proper disposition of his remains.

The Women's Liberation Association. Founded on March 8, 1961, the Women's Liberation Association was organized in the same fashion as the Farmers' Liberation Association, with its attendant cells, an executive committee of five to seven members, a permanent committee, and a cadre section. Emphasis was placed on ensuring that the members of the WLA retained as many friends outside the organization as possible. ${ }^{16}$ In the regulations of the WLA, three of the eight responsibilities of members were concerned with maintaining contacts with nonmembers as a means of influencing them. ${ }^{17}$ A study document published for new WLA members suggested that each member gain the sympathy of four nonmembers in order to "develop revolutionary awareness." 18

14. Conley, Communist Insurgent Infrastructure, p. 290.

15. DT-108, p. 51.

16. Vietnamese Communist Document 56, "Woman Proselyting Tasks," p. 12. Cited hereafter as VCD 56.

17. Conley, Communist Insurgent Infrastructure, pp. 284-86.

18. VCD 56, p. 13. 
The WLA and the Farmers' Liberation Association did not have the same recruiting goals. The Farmers' Liberation Association was supposed to embrace at least $5^{\circ}$ per cent of the farmers in the "liberated" areas, but a 1962 directive for the WLA set a limit of 20 per cent for the induction of its members. A larger percentage, the document warned, could create an organization so large that it could not be closely controlled by the Party. ${ }^{19}$ Although there is no apparent reason for this disparity in Party policy, it could be based on a belief that a women's organization equal in strength to an organization composed mostly of men might weaken the Party's control of the direction of the movement.

The Women's Liberation Association soon developed special-interest groups of its own, three of which were the Foster Mothers' Association, the Soldiers' Mothers' Association, and the Sisters' Association. Older women, whose status in Vietnamese village life is not fully appreciated by Westerners, ${ }^{20}$ proved to be valuable to the Party as members of the Foster Mothers' Association. Their major task was to serve as surrogate mothers to the younger members of the guerrilla forces who were away from home for perhaps the first time in their lives. Such an organization was not new to South Viet-Nam in the 1960's; the Party was continuing a practice inherited from the Viet Minh. In fact, the Foster Mothers' Association was the only mass organization mentioned specifically by Ho Chi Minh at the Second Party Congress of the Dang Lao Dong in $1951 .{ }^{21}$ Membership in the Foster Mothers' Association was open only to "virtuous women" over 50 years of age who also belonged to the Women's Liberation Association. Recruiting goals called for a maximum of eleven members in each "liberated" village. ${ }^{22}$

The Soldiers' Mothers' Association was made up of mothers whose sons were serving in the South Vietnamese Government armed forces. The primary value of the Soldiers' Mothers' Association was in its encouragement of the soldiers to desert, and, in that way, it was an instrument of the

19. Ibid., p. 7.

20. Gerald C. Hickey, Village in Vietnam, p. 105.

21. Ho Chi Minh, Ho Chi Minh on Revolution: Selected Writings, 1920-1966, ed. by Bernard B. Fall, p. 205.

22. VCD 56, p. 15 . 
Dang Lao Dong's binh van efforts. ${ }^{23}$ The Party wanted to enroll $5^{\circ}$ per cent of the mothers of Government soldiers living in "liberated" areas, $3^{\circ}$ per cent in the "temporarily liberated" areas, and 20 per cent in zones controlled by the Government. $^{24}$

One source mentioned that in Dinh Tuong's Giao Duc District, the Soldiers' Mothers' Association and Foster Mothers' Association were supplemented with yet another group, which was called the Sisters' Association. This group's mission was to act as substitute sisters for NLF guerrillas. ${ }^{25}$ The Sisters' Association was not formed to provide controlled sexual outlets for the young men. On the contrary, the Party frowned on sexual promiscuity, and it may be that by classifying younger girls as "sisters," the Party was attempting to dampen the ardor of its younger followers.

In spite of the emphasis placed on building the Women's Liberation Association and its ancillary organizations, the Party was discouraged by the results in the Kien Hoa-Dinh Tuong area in 1962 . The members, a year-end report concluded, were

not enlightened yet about the immediate interests, the lasting interests, the group interests, as well as the class interests. Because of lack of education, their thoughts are still imbued with self-belittlement, passiveness, lack of confidence in their own abilities.

Generally speaking, the Liberation Women['s] organization is still slovenly, loose, short of quality. The Liberation Women still fail ... to persuade, and educate the masses and to win over the masses. ${ }^{26}$

The Youth Liberation Association. The Dang Lao Dong was remarkably perceptive in its use of young people in the revolutionary movement. The Party's rejection of the Confucian relegation of youth to an inferior position in village life is illustrated by an analysis of Vietnamese youth that appeared in a Party document in 1962:

23. DT-108, p. 26.

24. Pike, Viet Cong, p. 261.

25. Rand Corporation and MACV J-2, File No. DT-87 (I), Studies of the National Liberation Front of South Vietnam, p. 6. Cited hereafter as DT-87.

26. VCD 56, pp. 3-4. 
Youth has its own characteristics which are not found in older people.... Youth hate the old things and are fond of new things. They love their ideas and do not fear difficulty or danger.... The interests of youth lead them to oppose the old society. ${ }^{27}$

Open to boys and girls from 16 to 25 years of age, the Youth Liberation Association was founded on December 25, 1961. The YLA was organized similarly to the Farmers' and Women's Liberation associations and was represented at the village level by an executive committee. Disregarding the theme of mutual aid dominant in the constitutions and regulations of the FLA and WLA, the Youth Liberation Association emphasized the revolutionary role of youth, declaring that its members were united for the purpose of "struggle against the Americans and Diem within the National Liberation Front of South Viet-Nam." 28

Like those of the FLA and WLA, the bylaws of the Youth Liberation Association reflected the Party's adherence to the policy of using the mass organizations as "transmission belts" for propaganda. Article 5 of the bylaws outlined the duties of the members:

1. Try to make propaganda to awaken the young people to their rights. Stay united with the other youths who are not members of the Association. 2. Make educational activities for young people and expand the recruitment of new members. 3. Guide the young people who are nonmembers and struggle with them to protect their essential rights.

4. Educate and take care of the young people and children. ${ }^{29}$

In keeping with the responsibility toward education of children, the YLA established doan thieu nhi xa ("Village Children's Groups"), which were composed of children from 10 to 15 years of age. Organized into cells of 6 to 12 children, each cell was supervised by a member of the Youth Liberation Association, who led the children in learning revolutionary songs, poems, and stories of revolutionary youth

27. Pike, Viet Cong, p. 183. 28. Ibid., p. 184.

29. Conley, Communist Insurgent Infrastructure, pp. 281-82. 
heroes. ${ }^{30}$ The input of cultural and educational materials was provided by the propaganda section.

The Dang Lao Dong's Control of Mass Organizations. The Dang Lao Dong's control of the mass organizations, which publicists for the National Liberation Front claimed were independent members of the united front, was revealed in a document describing the relationship of an early Dinh Tuong mass organization to the Party:

The Association of Peasants for Liberation, together with all the other classes and revolutionary forces belonging to the Popular Front for Liberation of South Viet-Nam, will contribute to strengthening the links of solidarity among the working classes under the leadership of the Lao Dong Party of VietNam. ${ }^{31}$

Also, the regulations of the Dang Lao Dong in South VietNam, which were published in October 1962 , reiterated the policy of the Dinh Tuong Province Committee:

Article 32.-The duty of the Party's association[s] is to carry out the policy and resolutions of the Party, to reinforce the Party's influence in the association, and to propose to the executive committee decisions regarding the policy and activities of the association.

Article 33.-The Party's association obeys the leadership of the Party's executive committee and [is] collectively responsible before the executive committee. $^{32}$

The organizational means by which the Party controlled the mass organizations, the "fractions" discussed by Hathaway, were intricate. Chapter $\mathrm{X}$ of the Constitution of the Dang Lao Dong, entitled "Party Groups," devoted three articles to explain the control apparatus for mass organizations:

Article 57.-In government agencies, in people's organizations and groups, the Party has also Party groups to operate under assignment of Executive Com-

3o. Pike, Viet Cong, p. 186.

31. U.S. Department of State, A Threat to the Peace: North Viet-Nam's Effort to Conquer South Viet-Nam, Department of State Publication No. 7308, p. 84.

32. VCD 50, p. 18. 
mittees of corresponding echelons.

Article 58.-The responsibilities of those Party groups are to implement the Party policies and resolutions, to strengthen the Party's influence, to study and recommend operations to be practiced in the organizations in which the group operates.

Article 59.-Party groups shall work under the leadership of the respective Committee echelons. Through the introduction of the Committee echelons, the Party groups of higher and lower echelons can establish contact for exchange of views and experience. ${ }^{33}$

The picture that emerges is one of small "fractions," or "Party groups," composed of highly disciplined Party members who were working within the mass organizations but taking their orders from the Party committee at that particular level. The Party group within the village Farmers' Liberation Association, as were the groups in the other mass organizations, was comprised of two kinds of Party members-those who operated openly in the FLA as acknowledged members of the Dang Lao Dong and those who kept their Party affiliations secret. The number of overt Party members in the mass organizations in Dinh Tuong varied according to the security situation in the individual villages. In accordance with Party policy, however, at least two open Party members were required to be on the executive committees of the mass organizations. Covert Party members in the various associations were instructed to "engage secretly in propaganda activities" that supported the stand of the overt Party members. ${ }^{34}$

At all costs, the covert Party members avoided identification with the Dang Lao Dong. They were warned not to use political idioms common to the Party or to divulge the existence of the Party groups, which were referred to as the "secret system" in Dang Lao Dong documents. The secret members in the mass organizations were charged with being good organization men and at the same time being alert for "active organization members" in order to make "acquaintances with them, cleverly propagandising to revolutionarily enlighten them." 35 Using the Farmers' Liberation Association

33. Conley, Communist Insurgent Infrastructure, pp. 249-50. 34. U.S. Department of State, Threat to the Peace, p. 95. 35. VCD 75, pp. 24-25. 
as an example, the relationship of the fractions, the mass organizations, and the Dang Lao Dong is shown in Figure 2.

Potentially valuable recruits were identified and the fraction passed on the information necessary for the security section to conduct background investigations. To further ensure the security of the fraction, Party members of that fraction were not entrusted with the names of members of fractions at other levels, which compartmentalized the organization structure. ${ }^{36}$

Party fractions within every mass organization at each level from village upward assured the Party of control by virtue of superior Party discipline and communications. At every level, the Party fraction obeyed without hesitation the instructions of the Dang Lao Dong committee of that level. Above the province level, the mass organizations did not exist; Party staff sections acting in the name of the Farmers', Women's, or Youth Liberation associations performed the administrative functions at higher echelons. ${ }^{37}$ Inasmuch as the three major mass organizations in the "liberated" village and the overt Dang Lao Dong element, which referred to itself as the People's Revolutionary Party, constituted the National Liberation Front, and inasmuch as orders from higher levels to lower passed through Dang Lao Dong channels, the village Party Committee was, for all practical purposes, the National Liberation Front. This point was underscored by the testimony of a former village Party secretary of Vinh Kim village, Long Dinh District:

Openly, we had to act on the Front's behalf and all the legal papers we used bear the name of the $\mathrm{Na}$ tional Front for the Liberation of South Vietnam.... Whenever we address the villagers, we call ourselves representatives of the Front Chapter but among ourselves we address each other as the Party Village Committee members. ${ }^{38}$

The mass organizations-the various liberation associations-which were painstakingly built in this period to act as "transmission belts" between the small Party nucleus and the village population at large, proved to be extremely effective.

36. Ibid., p. 25.

37. Pike, Viet Cong, pp. 171-72.

38. DT-99, p. 9. 
Figure 2. Relationships among the Dang Lao Dong, the Farmers' Liberation Association, and covert Dang Lao Dong fractions within the Farmers' Liberation Association

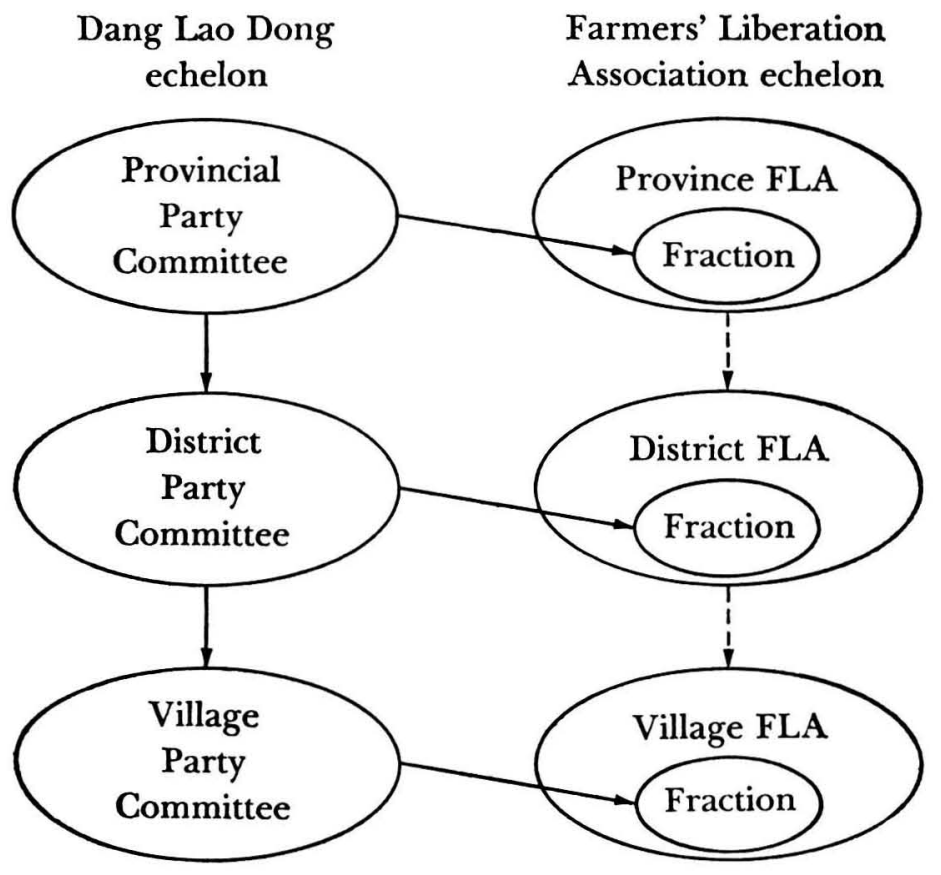

Actual Control Channels Apparent Control Channels 
In one report, submitted after the elimination of non-Party village leaders, one village Party secretary wrote:

At the present time our organizational strength is as follows: The Party totals 26 members, the Lao Dong Youth 30, the Farmers' Association 274, the Liberation Youth Group 150, the Liberation Women['s] Group 119; 2000 people, or two thirds of the villagers, take part in Party led activities. ${ }^{39}$

\section{Party Expansion Within the Village}

The Party's successful construction of the mass organizations transmuted the Party organization itself. The Party in the village grew in numbers of members and at the same time altered its structure in order to fulfill the demands for increased controls necessary for guiding the movement into the consolidation phase.

Recruitment. The Party drew upon two sources for the new members it needed: the mass organizations and a Partysponsored youth group, the Hoi Thanh Nien Lao Dong ("Labor Youth Association"). The mass organizations constituted a pool of more immediate potential members, even if they were less well indoctrinated and motivated than the members of the Labor Youth Association. This association represented a long-range effort directed toward training future Party members who were untainted by exposure to conflicting political ideas and beliefs. Members of the Labor Youth were slates that were, given the condition of youth, not required to be erased and wiped clean.

A villager did not become a member of the Dang Lao Dong by filing a membership application and paying an initiation fee. Rather, he acquired Party membership by progressive involvement, through successive stages. As Michael Conley observed:

One moved in toward the core of the [Party] through a series of concentric bands in which the demands made upon the individual gradually increased while his freedom of action and thought was progressively restricted..$^{40}$

39. VCD 2, p. 40.

40. Conley, Communist Insurgent Infrastructure, p. 60. 


\section{EXPANSION OF CONTROL}

The first step toward Party membership was membership in a mass organization. To all members, the mass organizations offered the prospect of a new system of supports, of reference groups that made up a political hierarchy extending upward from the village. The hierarchy provided the means by which the villager could attain benefits that had not existed in the traditional village. Membership in the mass organizations seemed to give the villager an opportunity to participate in the formation of policies that affected him and his future. The Farmers' Liberation Association was entrusted with land distribution; ${ }^{41}$ the Youth and Women's associations offered to elevate their members to a status level higher than that in a Confucian society. The mutual-aid features of the mass organizations, such as the funeral association and emergency loan funds for members, were faintly reminiscent of the traditional village practices and served to allay fears that support of the revolution might cause economic hardship. ${ }^{42}$

Once in the mass organization, the villager became subject to more intense indoctrination designed to inculcate support for the Party's objectives. The pattern of gradual involvement followed in Cho Gao District was typical of the process. The targets were members of the Youth Liberation Association. A former Party member related the steps taken by Party recruiters:

First, the cadres called on them, explained the Revolution's aims to them, instilled hatred against the Americans in their minds, and indoctrinated them with some views about the political situation. ....After that, the youths were entrusted with some minor duties such as gathering information.

A short time later, after the youths showed that they had some ability, the cadres started motivating them to go further with more important duties and indoctrinating them about more complicated political matters.

As the youths proved themselves in the execution of the "more important duties," those few who seemed ready to

41. Rand Corporation and MACV J-2, File No. DT-75 (I), Studies of the National Liberation Front of South Vietnam, p. 5 (Cited hereafter as DT-75); DT-79, p. 1.

42. DT-8o, p. 3. 


\section{THE VILLAGE WAR}

join the Dang Lao Dong were singled out for further training and indoctrination, at which point the cadre changed their tack:

It is noteworthy that the youth's instructors always acted on the Front's behalf. But, later on, when the youths showed that they were very eager to stick to the Revolution's cause and they had given proof that they had gone through dangers and difficulties with a high spirit, the VC, then, started to motivate them to join the Party. ${ }^{43}$

Another example of progressive involvement leading to Party membership was the case of a youth from Giao Duc District. The Dang Lao Dong had "liberated" his village in 1962 and established its mass organizations by the end of that year. In order to avoid being assigned to a civilian labor team because, in his words, he "preferred fun to hardships," the young man volunteered to join a Front-sponsored entertainment group that was directed by the Party's propaganda section. Later, a Party member told the youth that the South Vietnamese officials were aware of his involvement with the Party and would arrest him if at all possible. To escape arrest, the youth sought protection within the Front by joining a guerrilla unit in January 1963. Once in the unit, he was chosen to be a cell leader and finally joined a Party auxiliary group, whereupon he was promoted to squad leader. Finally, in September 1965, he was offered membership in the Dang Lao Dong, which he accepted.44 Thus, the path toward Party membership consisted of the individual's increased commitment during a period of more than three years.

The second source of Party members was the Labor Youth Association. The Labor Youth had been in existence before the National Liberation Front was organized, and to the Party, it was a "reserve troop" of the Dang Lao Dong, rather than another mass organization in the cast of the Farmers' or Youth Liberation associations. One Party member called the Labor Youth "the right arm of the Party, the reserve force for the future development of the Party, and the organization closest to the Party." 45 During 1962, after

43. DT-108, pp. 23-24.

44. DT-87, pp. 8-10.

45. DT-108, p. 27; VCD 50, p. 18. 


\section{EXPANSIONOF CONTROL}

the southern branch of the Dang Lao Dong had been redesignated the People's Revolutionary Party, the Labor Youth underwent a similar cosmetic operation and became known as the Thanh Nien Nhan Dan Cach Mang Mien Nam ("South Viet-Nam People's Revolutionary Youth Group").

The bylaws of the Labor Youth, published in 1960, stated that the association was responsible for educating "its members in the spirit of Marxism-Leninism and the conduct and morale of Chairman Ho." ${ }^{46}$ It was required to conduct its activities "under the direct leadership of the Party" and to carry out all decisions of the Dang Lao Dong. ${ }^{47}$ Membership was open to all young men and women from 18 to 26 years of age. Dues in the Labor Youth were much higher than those in the mass organizations, each member paying VN\$5 per month. The 1960 bylaws permitted the village Labor Youth echelon to retain two-thirds of the dues and forward the remainder, ${ }^{48}$ but by 1964 , Labor Youth Associations in Dinh Tuong retained only one-third of the monthly dues. Funds retained by the village associations were used for office and travel expenses. Also, the village association could disburse as much as VN\$100 to members who needed help with funeral or birth expenses. ${ }^{49}$

Unlike the Youth Liberation Association, the Labor Youth had no executive committee to guide it; rather, the village Labor Youth Association was directed by a secretary and deputy secretary. ${ }^{50}$ After the founding of the National Liberation Front and the subsequent creation of the Youth Liberation Association and the other mass organizations, the Labor Youth assumed a greater role in the revolutionary struggle. Recognizing that leadership of youth by peers would probably be most effective, the Dang Lao Dong utilized members of the Labor Youth as part of its Party fraction to control the Youth Liberation Association. Usually, members of the Labor Youth served as cell leaders in the YLA. ${ }^{.1}$

Control of the Labor Youth Association was much more stringent than that of the mass organizations. The Youth

46. Vietnamese Communist Document 82, Bylaws of the Lao Dong Youth League, p. 1.

47. Ibid., pp. 6-7.

48. Ibid., p. 7.

50. DT-99, pp. 9-10.

49. DT-108, p. 28.

51. DT-108, p. 28. 
Liberation Association had only one real command channel, that is, through the Party fractions, but the Labor Youth functioned under two parallel chains of command. First, the village Labor Youth Association was subordinate to the Dang Lao Dong village committee, which had a full Party member assigned to supervise Labor Youth activities. Secondly, the village association was responsive to orders from the next higher level of the Labor Youth, which was also under the dual-control system. This unique and potentially cumbersome system was described in Article 34 of the Dang Lao Dong regulations:

The Vietnamese Labor Youth Association is under the leadership of the Party. The association of one level (e.g. village) takes the leadership of the Party's organization of that level, and at the same time follows the leadership of the Vietnamese Labor Youth Association of the higher level. ${ }^{52}$

The reason for the Dang Lao Dong's keeping the Labor Youth on such a tight rein is not clear, just as its reason for restricting membership in the Women's Liberation Association is not clear; it may have been the recognition that unbridled power in the hands of a group long excluded from meaningful participation in politics could work against the best interests of the Party.

Initially, the Labor Youth was organized only at the village level, with no vertical structure through the district and upward. In December 1962, a study document published for prospective members of the Labor Youth stated that "diffculties" had restricted organization of the Labor Youth at that time to the village level..$^{53}$ Douglas Pike, on the basis of a Party document of 1964 , reported that the situation was still the same at that time, ${ }^{54}$ but in Dinh Tuong Province, the Labor Youth had developed to such an extent that district Labor Youth chapters had been organized. A former member of the Cho Gao District Party Committee reported that by early 1965, huyen doan ("district chapters") of the Labor

52. VCD 50, p. 19.

53. Vietnamese Communist Document 162, Labor Youth Association orientation, pp. 8-9.

54. Pike, Viet Cong, p. 152. 


\section{EXPANSIONOFCONTROL}

Youth had been formed and were operating under the leadership of the district Party secretary. In keeping with the earlier policy of strict control, the district Labor Youth secretary had to be a member of the Dang Lao Dong and be seated on the district Party Committee..$^{55}$

The Labor Youth Association was a direct pipeline toward membership in the Dang Lao Dong, whereas the mass organizations were less probable sources. Labor Youth members who reached the age of 26 without being found suitable for membership in the Party were dropped from the Labor Youth rolls. ${ }^{56}$ Those found acceptable did not undergo any kind of formal probation in the Party. For those persons aspiring to enter the Dang Lao Dong from the ranks of the mass organizations, it was a different matter. First, before receiving an invitation to join the Dang Lao Dong, prospective recruits from the mass organizations at the village level had to be cleared by the district Party Committee. ${ }^{57}$ The village Party secretary might have the authority to order summary execution of a member of the South Vietnamese Government, but he could not approve the nomination of a villager for membership in the Dang Lao Dong.

The standards established by the Dang Lao Dong Central Committee for membership were based primarily on social status. Poor and very poor peasants were accepted most readily, followed by middle and rich farmers. Intellectuals, members of the South Vietnamese Government, Catholics, and religious leaders were forced to undergo the most stringent probationary terms. ${ }^{58}$ This emphasis on social class had sound political and economic foundations. The lower two classes, given their lack of formal education, required less time to have their political thoughts restructured. Also, the poor and very poor peasants in South Viet-Nam have a long history of reliance on mutual assistance in farming, with neighbors helping one another in planting and harvesting crops. The middle and rich farmers, on the other hand, had access to more education, which impeded Party indoctrina-

55. DT-108, p. 28.

56. Vietnamese Communist Document 54, Regulations of the Vietnam Lao Dong Youth League, p. 8.

57. DT-99, p. 11.

58. VCD 5o, pp. 3-4. 
tion, and were generally wealthy enough to be able to hire such farm labor as they required. ${ }^{59}$ Thus, the poorer classes, well accustomed to communal labor, were more receptive to the tenets of Marxism.

All new members, regardless of social class, were required to meet certain probationary requirements. Every new member had to be sponsored by two Party members who agreed to be responsible for the conduct of the novice. The qualifications of the sponsors depended upon the social class of the prospective recruit. The following table illustrates probationary terms and standards for sponsors for entry into the Dang Lao Dong as of October 1962: ${ }^{60}$

\begin{tabular}{|c|c|c|}
\hline $\begin{array}{c}\text { Social } \\
\text { Class of } \\
\text { New Member }\end{array}$ & $\begin{array}{c}\text { Term of } \\
\text { Probation }\end{array}$ & $\begin{array}{c}\text { Party } \\
\text { Seniority } \\
\text { of Sponsors }\end{array}$ \\
\hline Very poor and & 4 months & 3 months \\
\hline $\begin{array}{l}\text { Middle and rich } \\
\text { peasants }\end{array}$ & 6 months & 6 months \\
\hline Intellectuals & 12 months & 9 months \\
\hline
\end{tabular}

No information available mentions the policy of the Party for the admission of landlords, but the Dang Lao Dong's earlier practice in North Viet-Nam indicates that only those landlords who were reclassified as middle, poor, or very poor peasants were admitted to Party ranks.

The length of probation fluctuated according to the membership level the Party wished to maintain. In Dinh Tuong, probationary terms for very poor and poor farmers were extended to nine months in 1965. For the middle and rich farmers, the probation was increased to one year. ${ }^{61}$ Such an increase may have been the result of the Party's desire to upgrade the quality of its members, since the membership had reached a quantitative level that met the Party's needs.

The number of women recruited continued to be small. Speaking of engaging women in Party activities throughout both Viet-Nams, Tran Minh Tan observed that the Party neglected "the role of women and the task of mobilizing them." He further stated that the "number of woman Party

59. Hickey, Village in Vietnam, p. 244.

6o. VCD 50, pp. 3-4.

61. DT-99, p. 5. 


\section{EXPANSION OF CONTROL}

members recently admitted . . . is nevertheless too small," which was due to the "feudalist ideology of many people, including Party members." 62

Party Organizational Changes. As the number of Party members increased and as Party control in the village demanded additional supervision, the Party organization within the village underwent structural changes in order to utilize its new recruits more efficiently and to exercise more complete sociopolitical control over the village inhabitants. The first Dang Lao Dong element in the village was the village Civil Affairs Committee, a three-man cell under the control of an established Party Chapter in a nearby village. When the Civil Affairs Committee enlarged itself to more than three members and promotion of the mass organizations had satisfactorily progressed, a village Party Chapter was formed and then assumed control of all village Dang Lao Dong members. ${ }^{\text {Bs }}$

The village Party Chapter was responsible for carrying out policies from higher echelons, establishing and controlling the mass organizations, and enforcing internal security and discipline. The chapter was led by a secretary and, if needed, an assistant secretary, both appointed by the district Party Committee. As more persons entered the Party, the span of control over subordinates became too broad to be adequately handled by the secretary and his assistant. Therefore, when Dang Lao Dong strength reached nine or more persons, a general meeting was called and a committee elected to serve as a staff for the secretary. Because Dang Lao Dong regulations required that one person be seated on the committee for every three members of the village Party Chapter, ${ }^{64}$ the resulting Chapter Committee usually contained from three to seven members. ${ }^{65}$ The cells within the

62. Tran Minh Tan, "Experiences of the Three Responsibilities in Hai Duong," reproduced, U.S. Department of Commerce, Translations of Political and Sociological Information on North Vietnam, No. 237, pp. 7-9.

63. Conley, Communist Insurgent Infrastructure, p. 244.

64. DT-99, p. 7.

65. Conley, Communist Insurgent Infrastructure, p. 244. 
village were then subordinated to the village Party Chapter Committee.

A Chapter Committee of ten or more persons would begin to exceed the control ability of the secretary; thus, the Dang Lao Dong structure was further modified when more than thirty people had joined the Party Chapter. At that point, the Party Chapter, in a fissionlike process, divided, and the village apparat then consisted of two or more Party chapters. Each chapter then elected its own secretary and assistant who, in turn, served on the village Party executive committee under the leadership of the village Party secretary ${ }^{66}$ Although some of the larger villages in Dinh Tuong had two or more Party chapters, this was the exception rather than the rule. Generally, villages under firm Party control had approximately fifteen Party members directed by a small Chapter Committee. ${ }^{67}$

\section{The Party, the Mass Organizations, and the People}

In Dinh Tuong, when the work with the mass organizations had progressed and the Party was assured of control of its creations, the Party began to erect the façade of the National Liberation Front government within the village. The objective of the Dang Lao Dong from 1960 to 1965 was to fit the Party apparatus and the executive committees of the mass organizations together to form a pre-emptive governmental system in the villages. ${ }^{68}$ Once a sufficient number of village governments were built, the Dang Lao Dong, in an upward process, established district and finally provincial National Liberation Front Liberation committees.

The actual form of village government established by the Dang Lao Dong varied for reasons of security and availability of manpower throughout Dinh Tuong Province. In Long Dinh District, for example, the large village of Vinh Kim was governed directly by the Party. The administrative and operational staff sections were supervised by the village Party secretary, as were the mass organizations. Although

66. DT-99, p. 7 .

67. Conley, Communist Insurgent Infrastructure, p. 45.

68. Pike, Viet Cong, p. 115. 


\section{EXPANSIONOFCONTROL}

official paper work of the Party Chapter Committee bore the impress of the National Liberation Front, no attempt had been made as of mid-1965 to establish a village Liberation Committee. ${ }^{69}$

In Cho Gao District, the Dang Lao Dong directly controlled its villages by the methods it used in Long Dinh until 1964. At that time, the Party began establishing full-fledged Liberation committees. Borrowing a page from the establishment of Viet Minh Liberation committees, ${ }^{70}$ the Dang Lao Dong fractions in the mass organizations proposed a single list of candidates in a village mass meeting and discouraged nominations from the floor. Through the mass organizations, pressure was generated to ensure that all the villagers voted and thus became supporters of the "freely elected" Liberation committees. ${ }^{71}$

The Liberation Committee elected in Hoa Dinh village of Cho Gao offers an example of the composition and affiliations of the members: ${ }^{72}$

\begin{tabular}{|c|c|}
\hline $\begin{array}{l}\text { Liberation Committee } \\
\text { Position }\end{array}$ & $\begin{array}{l}\text { Political/Class } \\
\text { Affliation }\end{array}$ \\
\hline Chairman & $\begin{array}{l}\text { Secretary, village Dang } \\
\text { Lao Dong Chapter. }\end{array}$ \\
\hline Deputy Chairman & $\begin{array}{l}\text { Member of Farmers' } \\
\text { Liberation Association. }\end{array}$ \\
\hline Secretary & $\begin{array}{l}\text { Dang Lao Dong member, chief } \\
\text { of military proselyting section. }\end{array}$ \\
\hline Member & $\begin{array}{l}\text { Dang Lao Dong member, cadre } \\
\text { in propaganda section. }\end{array}$ \\
\hline Member & $\begin{array}{l}\text { Member, Women's Liberation } \\
\text { Association. }\end{array}$ \\
\hline Member & Cao Dai representative. \\
\hline Member & Buddhist representative. \\
\hline Member & Catholic representative. \\
\hline Member & Intellectual class representative. \\
\hline
\end{tabular}

69. DT-99, p. 9.

70. Rima Rathausky, ed., Documents of the August 1945 Revolution, pp. 4-5.

71. Conley, Communist Insurgent Infrastructure, p. 94.

72. DT-108, p. 37. 


\section{THE VILLAGE WAR}

Although the number of overt Party members did not exceed the two-fifths limit established by the Dang Lao Dong, the dominant positions of the Party members, supported by the members of the Party-controlled mass organizations, clearly guaranteed that the Liberation committees would not fall under the control of a non-Party group. By 1965 , the Dang Lao Dong had established Liberation committees in 16 of the 20 villages in Cho Gao District. ${ }^{73}$

In spite of local variances, the functional tasks of the village Party chapters in Dinh Tuong were relatively consistent. The major sections established by the Party were military affairs, military proselyting, finance, security, propaganda, and civil affairs. The civil affairs section served as a link for the Farmers', Women's, and Youth Liberation associations. ${ }^{74}$ Members of most of the administrative and operational sections could be non-Party members, but leadership of the sections was reserved for members of the Dang Lao Dong or Labor Youth. ${ }^{75}$ The functions and organization of the propaganda section have been discussed; those of the remaining sections are outlined below.

The chief of the Ban Quan Su ("military affairs section"), the third most powerful figure in village government after the secretary and deputy secretary, was required to be a Party member. The Ban Quan Su was responsible for the training and employment of village guerrillas under the direction of the village Party secretary. When required for combined operations with district local forces or provincial main forces, the operations of the village guerrillas were coordinated between district and village by the military affairs chief, with the knowledge and approval of the village Party secretary. The chief of the Ban Quan Su was also responsible for such aspects of internal security as enforcement of directives about communal discipline. The task of political surveillance was left to the security section. ${ }^{78}$

The Ban Binh Van ("military proselyting section") was in charge of inducing members of the South Vietnamese armed forces to desert. Two major means used by the Ban Binh Van were clandestine agents within nearby Government military units and persuasion of the families of Gov-

73. Ibid.

75. DT-99, p. 9.
74. Ibid., p. $3^{6}$.

76. DT-86, p. 10. 
ernment soldiers living in the village, a task made simpler through the use of the Soldiers' Mothers' Association. ${ }^{77}$ The military proselyting section was required to coordinate closely with the security section, as well as the military affairs section, in order to prevent the elimination of its clandestine agent nets. ${ }^{78}$

The primary task of the Ban Kinh Tai ("finance section"), which was in charge of raising funds for the Dang Lao Dong, was the collection of taxes. The finance section also fulfilled the function of coordinating the logistic support from village resources that local and main-force military units needed as they passed through the village. ${ }^{79}$

One of the first sections to be formed once the Party had succeeded in penetrating a village was the Ban An Ninh ("security section"). It filled a dual role. In relation to the villagers, the security section maintained a constant surveillance in order to detect the reappearance of any "reactionary" elements in the village. ${ }^{80}$ The security section was also charged with investigating Dang Lao Dong cadres and with reporting any mistakes, errors, or evidence of "wrongthinking" to the village Party secretary. ${ }^{81}$ The security section was responsible for carrying out executions and assassinations in accordance with Party directives and policy. In contrast with other sections, all members of the An Ninh were required to be Party members.

\section{Taxation}

With the Party machinery synchronized with the mass organizations, the Dang Lao Dong was in a position by 1963 and 1964 to embark on the next step of the expansion phase, taxation. Taxation was an issue far larger than the mere gathering of revenue. The levy of taxes demonstrated the Party's assumption that it was politically well enough entrenched to initiate such a measure, and the villager's pay-

77. DT-108, p. 26.

78. DT-86, p. 8.

79. W. P. Davison, Some Observations on Viet Cong Operations in the Villages, p. 54.

8o. Conley, Communist Insurgent Infrastructure, p. 49.

81. Davison, Observations, pp. 54-55. 
ment of the taxes was an acknowledgment of the Party's legitimacy.

The Dang Lao Dong's diversion of taxes from the South Vietnamese Government represented one of the first harnessings of the power potential of the Vietnamese village and constituted the initial exercise of the political power of the village Party Chapter. Implementation of the Dang Lao Dong fiscal policies varied, as did its military and political operations, according to the degree of control the Party enjoyed in the village. Hence, throughout Dinh Tuong, the Party's taxation policies were not started at the same time. In general, after the Party successfully established its mass organizations, it was able to initiate taxation. Its methods mirrored those used for political subversion; the Dang Lao Dong began its economic operations in a target village by asking for very little and then escalated its demands as it consolidated political control. In the time period 1960 to 1964 , the major concern of Party fiscal planners seems to have been raising revenues through taxes, but the rate of taxation was not used, as it had been in North Viet-Nam, to ruin the bourgeoisie and pave the way for the dictatorship of the proletariat. ${ }^{82}$

The first revenues collected by the Dang Lao Dong in Dinh Tuong were called not thue-ma ("taxes") but lac quyen ("contributions") or dam phu moi quan ("troop support gifts"). Contributions were collected in cash, rather than bulky crops that were difficult to transport, and were graduated on the basis of social class as determined by the village finance section. ${ }^{83}$ The scales varied widely from district to district and from village to village in the same district, which demonstrated a high degree of decentralization and flexibility within the Party. The following table shows the variances in contribution scales for villages in the districts of Cho Gao, Cai Lay, and Chau Thanh. ${ }^{\text {st }}$

82. Hoang Van Chi, From Colonialism to Communism: A Case History of North Vietnam, p. 76.

83. DT-79, p. 2.

84. For Cho Gao, ibid.; for Cai Lay, DT-61, p. 7; for Chau Thanh, Rand Corporation and MACV J-2, File No. DT-65 (III), Studies of the National Liberation Front of South Vietnam, p. 5 (Cited hereafter as DT-65). 


\section{EXPANSION OF CONTROL}

\begin{tabular}{lccc}
\multicolumn{1}{c}{$\begin{array}{c}\text { Xuan Dong } \\
\text { village } \\
\text { Clacial }\end{array}$} & $\begin{array}{c}\text { My Hanh Trung } \\
\text { Cho Gao }\end{array}$ & $\begin{array}{c}\text { village } \\
\text { Cai Lay } \\
\text { District }\end{array}$ & $\begin{array}{c}\text { District } \\
\text { village } \\
\text { Chau Thanh } \\
\text { District }\end{array}$ \\
Very poor & VN\$ 200 Exempt & VN\$ 100 \\
Poor & unknown & VN\$ 1000-2000 & $200-300$ \\
Middle & unknown & $3000-5000$ & $400-500$ \\
Rich & unknown & $5000-7000$ & $1000-1500$ \\
Landowners & 15,000 & $5000-10,000$ & $2000+$
\end{tabular}

The monies collected in the form of contributions were substantial. A Party official reported that contributions from Trung An, the village with the lowest scale of the three villages examined, amounted to VN $\$ 1,000,000$ in $1963^{85}$ The former secretary of the Party Chapter in Dang Hung Phuoc village, which is in the same district as Xuan Dong village, stated that income from the lac quyen came to VN\$600,000 in the same year. ${ }^{86}$ Contributions were difficult to collect, however, in Catholic areas. Xuan Dong village, for example, consisted of eight hamlets, five of which were predominantly Catholic. In 1963, the Party hoped to collect VN\$300,000 in revenues. The three non-Catholic hamlets proved no problem, but the Catholics refused to contribute and the Dang Lao Dong received only VN\$102,000 from the village. ${ }^{87}$

Once the Dang Lao Dong Party Chapter firmly controlled a village, higher Party finance sections set tax goals for the village as a whole to meet, a practice reminiscent of the days of Imperial Viet-Nam. In most of the Dinh Tuong villages, the quota was met by the agricultural tax. The agricultural tax was first levied in Dinh Tuong's Cai Lay District, a Party stronghold for many years, in 1963, and most of the remaining districts followed suit in $1964^{88}$

Before the Dang Lao Dong began taxation, village Party chapters embarked upon carefully considered psychological campaigns in order to persuade the villagers to accept the tax policy as equably as possible. The Party cadre promoted an activity that they termed the binh san lwong ("communal

85. DT-65, p. 5.

87. DT-79, p. 2.

86. DT-49, p. 9 .

88. Rand Corporation and MACV J-2, File No. DT-55 (II), Studies of the National Liberation Front of South Vietnam, p. 2. Cited hereafter as DT-55. 
determination of yield"). This device was, as one Party offcial described it, a way to let the villagers "discuss their taxes and to adjust them to their actual production." ${ }^{89}$ In practice, the villagers were coerced into accepting a predetermined tax rate based not on actual yield of their fields, but on an artificial production rate derived from the manipulation of the social pressures generated by the mass organizations.

The binh san luong was initiated in successive phases. First, all members of the village Party Chapter secretly studied the recommendations of the village finance section's plans to meet the revenue goal fixed by higher Party echelons. When agreement was reached within the Party, members of the Labor Youth and the mass organizations were indoctrinated. When the Labor Youth and association members, appropriately referred to by the Party as "backbone elements," reached a consensus on the Party tax goal for the village, further work was done to determine what the rice yield per mau (1.32 acres) would have to be in order to attain the revenue goal. Eventually, a target production figure of so many gia (approximately 40 bushels) of rice per mau of land was determined. During the entire discourse, the primary consideration was to meet the Party revenue objective; little or no attention was paid to the historical production of the village fields. With a production figure already in mind, the village secretary called a mass meeting of the village..$^{20}$

The secretary began the meeting with an analysis of the revolutionary situation, stressing the need of the soldiers of the National Liberation Front for food and armaments in the struggle against the forces of the United States and Ngo Dinh Diem. After setting the mood, he described the policy of the agricultural tax to the villagers and then asked them to discuss among themselves the production rates of their lands. The backbone elements, the Labor Youth and the associations, agitated for the predetermined yields per mau and accused reluctant neighbors and friends of being laggards. Each person present was aware that the village had a communal tax quota and thus was motivated to see that his neighbors did not claim a productivity low enough to move them into a lower bracket. When at least half of those present

89. DT-65, p. 5 .

90. DT-108, p. 10. 


\section{EXPANSION OF CONTROL}

agreed on the theoretical production figure, the discussion was closed, and the village secretary ended the meeting with the observation that only "reactionary elements" would have a difficult time meeting the production goals set by the "democratic" process of the binh san luong. ${ }^{91}$

The basis of the agricultural tax was the theoretical yield arrived at by the binh san luong, not the actual production at the end of harvest. The following data show that the agricultural tax scales for Dinh Tuong were considerably more consistent than the quotas established for the "troop support gifts." 92

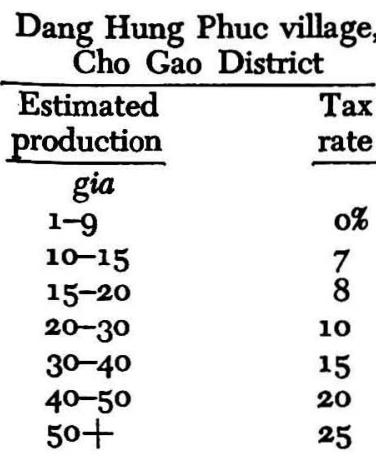

\begin{tabular}{|c|c|}
\hline $\begin{array}{l}\text { Estimated } \\
\text { production }\end{array}$ & $\begin{array}{l}\text { Tax } \\
\text { rate }\end{array}$ \\
\hline gia & \\
\hline $1-15$ & o\% \\
\hline $15-20$ & 7 \\
\hline $21-25$ & 8 \\
\hline $26-30$ & 9 \\
\hline $31-40$ & 10 \\
\hline $4^{1-50}$ & 12 \\
\hline $51-60$ & 14 \\
\hline $61-70$ & 16 \\
\hline $71-80$ & 18 \\
\hline $81-90$ & 20 \\
\hline $91-100$ & 22 \\
\hline $101-120$ & 24 \\
\hline $120+$ & 25 \\
\hline
\end{tabular}

The variations that did exist could have been due to differences in land fertility, distribution of social classes, and other factors.

The annual tax for a family was computed by dividing the total estimated yield of the land the family tilled by the number of persons in the family. Using the "individual ration" thus obtained, the tables were entered and the tax rate determined. This percentage was then applied against the total estimated yield, resulting in a number of gia of paddy. The total tax owed the Party in cash was determined by

91. Ibid., pp. 10-11.

92. For Dang Hung Phuc village, ibid., Pp. 11-12; for Hoa Dinh village, DT-49, p. 9. 


\section{THE VILLAGE WAR}

multiplying the amount of paddy by the current market price of rice. ${ }^{83}$

For example, for a family of six persons living in Hoa Dinh village, Cho Gao District, whose total estimated yield was 200 gia of paddy, the table was entered at $200 / 6$, or 33 gia, yielding a tax rate of 10 per cent. The tax in kind amounted to $0.10 \times 200$, or 20 gia. During 1964, when the price of paddy per gia was approximately VN\$100 in Cho $\mathrm{Gao}^{94}$ this family owed taxes in the amount of $\mathrm{VN} \$ 2,000$. The Party, however, was not entirely finished with the farmer. When the actual yield was sold at market, the Dang Lao Dong then imposed an additional tax. Known as the "market" tax, a charge of 5 to 10 per cent was levied on all farm goods sold at market, which included not only paddy but also pork, onions, and chickens. ${ }^{95}$ Thus the Hoa Dinh family found itself in a position of paying the agricultural tax on an estimated yield of 200 gia, then actually producing perhaps only 180 gia for sale and having this taxed also-a situation that would result in a total tax of $\mathrm{VN} \$ 3,800$.

Other conditions also intensified the peasant's economic burden. In some instances, fearing that if the Government ever returned it would press for collection of back taxes, farmers paid both the Party's and Government's land taxes. ${ }^{26}$ In Cho Gao District's Hoa Dinh village, the Party collected the crop shares due the landlords and then taxed the peasants in addition. One respondent ended up paying $V N \$ 1,500$ in cash in taxes and 25 gia of paddy for in-kind "rent." 97 Some peasants, aware that the landowner was not getting his rent, dispatched a member of the family to the Governmentcontrolled area to explain the situation and to pay a portion of their rent. ${ }^{98}$

Additional revenues were obtained by means of trans-

93. DT-108, p. 12.

94. Ibid.

95. DT-61, p. 8.

96. Rand Corporation and MACV J-2, File No. DT-46 (I), Studies of the National Liberation Front of South Vietnam, p. 1; Rand Corporation and MACV J-2, File No. DT-56 (I), Studies of the National Liberation Front of South Vietnam, p. 1 (Cited hereafter as DT-56).

97. DT-75, p. 2.

98. Incident witnessed by author in Long An Province, April 1965 . 


\section{EXPANSION OF CONTROL}

port duties, "production" taxes, and the sale of "liberation bonds." Where deemed feasible, village finance cadre collected transport "taxes" from boats going to market along navigable streams or canals. ${ }^{99}$ For crops of coconuts, the "production" tax called for payment of VN $\$ 5,000$ per mau of trees five to ten years of age and VN\$10,000 per mau for trees over ten years of age. ${ }^{100}$ By 1965 , the Party was selling "liberation bonds" in the villages it controlled. Issued in denominations of $\mathrm{VN} \$ 500$ and $\mathrm{VN} \$ 1,000$, these bonds were supposedly redeemable within five years, ${ }^{101}$ and during that time, the holders of the bonds had a stake in the future success of the Dang Lao Dong.

The income from all these sources provided the Party with substantial funds. Although figures are not available that can provide a concise picture of the revenues raised in Dinh Tuong, it may be adduced from scattered sources that the amounts collected were considerable. Dang Hung Phuoc village's total taxes amounted to VN\$800,000 in $1964 ; ;^{102}$ those from Tam Hiep equaled this amount. ${ }^{103}$ My Hanh Trung village in the strong Party area of Cai Lay District provided nearly VN $\$ 1,000,000 .^{104}$ Chau Thanh District in 1965 was reported to have raised $\mathrm{VN} \$ 13,000,000 .{ }^{105}$

Most of the funds from taxation were forwarded to higher headquarters and were not spent within the villages. Although the Party specified that 10 per cent of all revenues raised would be kept by the village Party Chapter, in practice, only a few thousand piasters were retained each year for administrative expenditures. Two separate sources reported that as village Party secretaries, they were permitted to keep only VN $\$ 5,000$ at their level. ${ }^{106}$

The year 1965, a time of rising prices throughout South Viet-Nam, saw a tremendous increase in Party tax rates. Although one Party official claimed the increase to be approximately 40 per cent, ${ }^{107}$ many reports from Dinh Tuong indicate that the increase ran anywhere from $5^{\circ}$ per cent to

99. DT-108, p. 79.

101. Pike, Viet Cong, p. 299.

103. DT-59, p. 27.

105. DT-65, p. 5 .

106. DT-49, p. 11; DT-61, p. 8.

107. DT-79, p. 2.
100. DT-63, pp. 4-5.

102. DT-49, p. 9 .

104. DT-61, p. 8. 
100 per cent. ${ }^{108}$ One case was reported of a farmer who had paid $V N \$ 1,000$ in 1963 paying $V N \$ 3,500$ in $1965 \cdot{ }^{109}$ In areas where the conditions permitted double-cropping, the Party began taxing the second crop, as well as the first, ${ }^{110}$ gaining revenues from a source that traditionally the landlord had left entirely for his tenants' income. ${ }^{111}$

Although the Party did permit exemptions from taxes and did waive the tax increase of 1965 in cases of demonstrated hardship, ${ }^{112}$ the coercion used by the Dang Lao Dong in collection of taxes represented one of the first uses of terror to enforce its control, rather than to disrupt the control of another governing body. Such actions ranged from lining up and shooting those who did not pay their taxes ${ }^{113}$ to less violent means. The Party conducted "re-education" sessions in which tax dodgers were instructed about the policies of the National Liberation Front and the responsibilities of the people for supporting the revolutionary struggle. Using filial piety as a lever, the Party usually selected family heads to attend the re-education courses. Often the process involved outright kidnapping and extortion. One village Party secretary stated that persons from his village were sent to reeducation "centers" located in areas frequently bombarded by the Government. The subjects, the official explained, were so frightened by this experience that they "wrote to their kinsmen to pay taxes in order to have them set free." 114 Another source revealed that his parents were taken away for re-education five times for protesting what they considered to be excessive taxes. ${ }^{115}$ In other cases, the mere presence of a few armed village guerrillas accompanying the finance section cadre on their rounds was enough to prevent arguments and protests from other unhappy peasants. ${ }^{116}$

Important as the actual revenues from taxation were to the Dang Lao Dong, the political significance of the agri-

108. DT-55, p. 2.

109. Davison, Observations, p. 87.

110. DT-64, pp. 7-8.

111. Hickey, Village in Vietnam, p. 46.

112. DT-56, p. 1.

113. Peter Grose, "Vietcong's 'Shadow Government' in the South," New York Times Magazine (January 24, 1965), 66.

114. DT-99, p. 11.

115. DT-55, p. 2.

116. DT-8o, p. 1. 


\section{EXPANSIONOFCONTROL}

cultural tax was also considerable. The act of imposing taxes indicated the Party's confidence that it controlled a rural village; the peasant, by paying taxes to the Party, was acknowledging the Party's legitimacy. That the Party's political fortunes were on the rise in Dinh Tuong in 1964 was evident from the widespread implementation of the agricultural tax in that year. After the expansion of the Party organization, it remained only for the Dang Lao Dong to consolidate its control over the villages in order to acquire active support for its attempt to destroy the South Vietnamese Government. 
We must not forget the consolidation

of the base areas, the chief task being to arouse and organize the masses and to train guerrilla

units and local armed forces.

-Mao Tse-tung,

Selected Military Writings of Mao Tse-tung

\section{CONSOLIDATION OF POWER}

After the Dang Lao Dong had established its mass organizations and had expanded its control in the villages of Dinh Tuong Province, the Party consolidated its position and directed the energies of the population against the Government of South Viet-Nam. Within the village, consolidation meant forming the kind of militarized society envisioned by Le Nam Thang, in which all persons became involved in some way in the revolutionary struggle while the Party, for its part, monitored and controlled the lives of the village inhabitants. ${ }^{1}$ The major consolidation efforts of the Dang Lao Dong focused on the Party's formation of organized village paramilitary forces, the regimentation of the population within the village, and the Party's use of village forces and the mobilized population as a revolutionary instrument.

\section{Village Paramilitary Forces}

The armed forces of the National Liberation Front were divided into two functional groups: the "regular" military and the village paramilitary elements. The Than Phan Quan

1. Le Nam Thang, "Grasp Basic Principles of People's War," reproduced, U.S. Department of Commerce, Translations of Political and Sociological Information on North Vietnam, No. 237, p. 37 . 
$S u$ ("regular military forces") were the most thoroughly indoctrinated and trained and constituted the Dang Lao Dong's full-time military arm. ${ }^{2}$ The Than Phan Quan Su was further divided into Quan Doi Chu Luc ("Main Force") and Bo Doi Dia Phuong ("Local Forces") ${ }^{3}$ Under the generic term Dan Quan Du Kich ("civilian guerrillas"), the Dang Lao Dong established its village paramilitary forces. ${ }^{4}$ The Du Kich were further divided into three groups: the $\mathrm{Du}$ Kich Chien Dau ("combat guerrillas"), the Du Kich Xa ("village guerrillas"), and the Tu Ve Nhan Dan ("self-defense militia").

The combat guerrillas were the best armed and best trained of the $\mathrm{Du}$ Kich forces and served on a full-time basis. They were supported by rice "contributions" from village families, each of whom was required to furmish as much as three liters of rice each month for this purpose. ${ }^{6}$ The armament of the combat guerrillas was an assortment of French, German, Russian, and American weapons, including rifles, carbines, and sometimes a submachinegun. ${ }^{7}$ The village guerrillas and the self-defense militia members, whose weapons were more rudimentary than those of the combat guerrillas, supported themselves by farming. The village guerrillas were generally armed only with grenades, antipersonnel mines, and "naily-boards"-spiked foot-traps. ${ }^{8}$ The self-defense militia was usually unarmed and was employed in transportation and sabotage work. ${ }^{9}$ The sizes of Du Kich units ranged widely throughout Dinh Tuong Province. One source reported that his village had 15 men, ${ }^{10}$ another had two platoons of about 60 to 70 persons, ${ }^{11}$ and a "strong" village Du Kich reached nearly 100 members. ${ }^{12}$

When they were not supporting the regular military forces, the Du Kich were supervised by the chief of the military affairs section under the direction of the village Party

2. Douglas Pike, Viet Cong, p. 234 .

3. Michael Charles Conley, The Communist Insurgent Infrastructure in South Vietnam: A Study of Organization and Strategy, U.S. Department of the Army Pamphlet No. 550-106, p. 118.

4. Pike, Viet Cong, p. 234.

6. DT-59, p. 22.

8. DT-61, p. 1.

10. DT-87, p. 1.

5. DT-61, pp. 1-2.

7. DT-87, p. 1.

9. DT-108, p. 9.

12. DT-61, pp. 1-2.

11. DT-108, p. 9. 
secretary. ${ }^{18}$ The limited capabilities of the village forces prevented their being committed in combat against the superior forces of the South Vietnamese Army. In fact, one Du Kich member, in his four years of service, had never been in an engagement against regular forces. ${ }^{14}$ Rather, the Du Kich were employed by the village Party secretary to stand guard in the village at night, check the identity of strangers, accompany the propaganda section cadre on missions, and help the finance section collect taxes. ${ }^{15}$ Their intimate knowledge of the countryside and its inhabitants made the Du Kich especially well suited for establishing roadblocks, attacking Government villages, and harassing lonely outposts. ${ }^{16}$ The combination of their familiarity with the local terrain and their lack of military strength often gave rise to tactical improvisations that bordered on the bizarre. In one instance, a guerrilla force planned to raid a hamlet under Government control. Instead of attempting to breach the impressive earthworks in a frontal assault, the Du Kich waited outside the hamlet, seized a commercial bus, removed its paying passengers, then drove the vehicle into the hamlet past the unsuspecting guards. ${ }^{17}$

Another specialty of the Du Kich was the "buying" of isolated Government posts. The military proselyting section would make contact with a Government soldier who, for a sum, would help the Du Kich take the post by surprise and with a minimum of fighting. The turncoat was then paid and offered land and a safe-conduct pass to assist him in settling in another area. ${ }^{18}$ The proselyting section was authorized to pay up to VN $\$ 20,000$ in rewards for such operations, although more funds could be obtained on application from the district Party Committee. ${ }^{19}$

Service in the $\mathrm{Du}$ Kich was particularly attractive to the villager who did not want to leave his home, for it permitted him to discharge his obligations to the National Liberation Front and remain in the village. ${ }^{20}$ In Dinh Tuong,

13. DT-86, p. 8.

15. DT-79, p. 10; DT-87, p. 15.

14. DT-55, p. 5 .

16. DT-87, p. 15.

17. Bernard B. Fall, The Two Viet-Nams, pp. 367-68.

18. DT-108, p. 22.

20. DT-85, p. 12. 


\section{CONSOLIDATION OF POWER}

there were some who opposed the Party but joined the Du Kich in order to avoid conscription in the South Vietnamese Army because the Government would require them to serve in other parts of Viet-Nam. ${ }^{21}$ The daily activity of the combat guerrillas, the elite of the Du Kich, was not extremely strenuous as evidenced by the following schedule for a unit in Chau Thanh District: ${ }^{22}$

$\begin{array}{cl}\text { 4:00-5:00 A.M. } & \text { Patrol around village } \\ \text { 5:00-6:30 } & \text { Breakfast } \\ \text { 6:30-10:00 } & \text { Combat or political training } \\ \text { 10:00-5:00 P.M. } & \text { Free time } \\ \text { 5:00-6:00 } & \text { Criticism-self-criticism session } \\ & \text { (kiem thao) } \\ \text { 6:00-bedtime } & \text { Free time }\end{array}$

The lack of thorough military training and the nature of the missions assigned the $\mathrm{Du}$ Kich have persuaded some observers that the Du Kich were not important. Far from being the "hapless cannon-fodder" described by Bernard Fall, ${ }^{23}$ the village forces served the Dang Lao Dong as a valuable political instrument. If the guerrilla is evaluated as a member of a village mass organization who worked overtime, not as a poorly trained, part-time soldier, the shift in perspective reveals the Du Kich member to be a member of an elite civilian special-interest group. ${ }^{24}$ Such a position worked to the advantage of the Party in that it placed the guerrilla in the Dang Lao Dong camp and, at the same time, denied his use as a source of manpower to the South Vietnamese Government. ${ }^{25}$ Because his neighbors considered him a local civilian, the guerrilla was the means by which Vo Nguyen Giap had recommended that political and military tasks be translated into forms of revolutionary struggle within the village. ${ }^{26}$

21. Rand Corporation and MACV J-2, File No. DT-94 (II), Studies of the National Liberation Front of South Vietnam, p. 6. Cited hereafter as DT-94.

22. DT-59, p. 22.

23. Fall, Two Viet-Nams, p. 351.

24. Conley, Communist Insurgent Infrastructure, p. 90.

25. Pike, Viet Cong, p. 235.

26. Vo Nguyen Giap, Banner of People's War, the Party's Military Line, pp. 32-33; Vo Nguyen Giap, People's War, People's Army, p. 55. 


\section{Consolidation of Population Control}

Consolidation of the Dang Lao Dong village leadership brought upon the villager a wide range of controls that extended Party power over every portion of his life. At the same time that the Party initiated these controls, it also fostered a sense of insecurity and distrust among the village inhabitants and thereby created an environment in which the villager himself was forced to control his own actions, which eased the enforcement burden on the Party village machinery. The villager in the Party or one of its mass organizations was placed under additional internal disciplinary controls designed to encourage behavioral norms that served the Party's larger interests at the expense of personal freedom. The means of control fall into six distinct classifications: village surveillance, manipulation of information, restriction of movement, communalization of labor, enforcement terror, and Party internal control devices.

Village Surveillance. The Party rationale for surveillance within the village followed the logic expressed in the syllogism:

Spies are known to be clever and must be watched.

Anyone might be a spy.

Since anyone might be a spy, everyone must be watched. An internal Dang Lao Dong document used this line of reasoning as justification for programs designed to "promote the spirit of secrecy among the rural people." ${ }^{27}$ A similar approach was taken by Vuong Si Dinh in describing the measures taken to eliminate "spies" in North Viet-Nam's Nghe An Province. Portraying the "enemy" as capable of "devilish ruses and tricks," he observed that the Party had turned the village into "a vast network of 'thousand eyes, thousand ears' that is always vigilant." ${ }^{28}$ Obviously, any behavior not condoned by the Party could not go long undetected in a village so organized.

27. VCD 2, p. 65.

28. Vuong Si Dinh, "Air Defense in T. Rural Community, Nghe An," reproduced, U.S. Department of Commerce, Translations of Political and Sociological Information on North Vietnam, No. 232, p. 10. 
In its efforts to establish a tight cordon about each and every individual in the Dinh Tuong villages, the Dang Lao Dong employed both mutual and organizational surveillance methods. Mutual surveillance has been a means by which Sinicized societies have traditionally maintained internal order and discipline. The pao chia system, begun in China's Ch'in dynasty and given impetus by the reformer Wang Anshih in the Sung dynasty, depended upon the family to control the actions of the individual and grouped families into definite units, which were then accountable to a government representative for the conduct of any person within the group. ${ }^{29}$

The pao chia system was adapted by the Dang Lao Dong in rural Viet-Nam, generally based on family "clusters" consisting of three to five families. ${ }^{30}$ The Party urged the families within the groups to watch each other for any misconduct or counterrevolutionary behavior, thus neighbors were continually alert and frightened that any incident not reported to the village Party Chapter or Liberation Committee would result in sanctions against themselves and their families. As one respondent put the situation, "Everyone was followed by someone else, and yet nobody knew about it."

In those cases where the mutual surveillance system left loopholes for deviant behavior, the security section provided the means for organizational surveillance. The implementation of the mat hoi vien ("spying and security organization") was based on the Ban An Ninh's categorization of potential security threats. The village society was divided into two groups: the "true comrades," for whom the mutual surveillance system sufficed, and the "temporary allies in the antiAmerican struggle," who were the objects of the closer surveillance of the An Ninh network of secret agents. ${ }^{32}$ Included in the latter category were persons who had been

29. Edwin O. Reischauer and John K. Fairbank, East Asia: The Great Tradition, p. 374.

30. Floyd L. Singer, Control of the Population in China and Vietnam: The Pao Chia System Past and Present, p. 14; Vuong Si Dinh, "Air Defense," 10.

31. W. P. Davison, Some Observations on Viet Cong Operations in the Villages, p. 32.

32. Rand Corporation and MACV J-2, File No. DT-83 (I), Studies of the National Liberation Front of South Vietnam, p. 4 . 
"reduced in prestige," families with members serving the Vietnamese Government, "crooks and criminals," and a catchall group of persons "who gamble, drink, and often oppose the policy of the Front." 38 The reports from the agents involved in organizational surveillance and from the family clusters formed the basis for periodic situation reports produced by the security section for higher level Party use.

Information Manipulation. The Dang Lao Dong's manipulation of information went far beyond mere censorship and attempted to change the very Weltansicht of the peasant. Media censorship was, of course, an integral part of the attempt to change the peasant's view of the world in which he lived. As early as mid-1962, the Party promulgated a directive that forbade Party members and military forces to listen to "enemy" broadcasts. "Enemy stations" were identified as Voice of America, British Broadcasting Corporation, and any broadcasts from Australia, Japan, Taiwan, or Thailand. The same regulation also directed that the village propaganda sections persuade the population to cease listening to these stations. ${ }^{34}$

In practice, the lower-echelon Party groups disregarded the instructions to persuade the villagers not to listen to "outside" broadcasts and flatly prohibited them from tuning in unauthorized stations. ${ }^{35}$ News and commentaries from nonParty sources were not the only targets; traditional South Vietnamese music, the lamentful dieu nam, was denounced for causing people to become "lethargic." Instead, the propaganda sections promoted the more lively dieu bac from North Viet-Nam. ${ }^{36}$

Personal mail and newspapers were also subject to Party censorship. Since the Party controlled the mail that moved along the giao lien ("liaison system") from village to village and between the villages and the military units, censorship was an easy matter. Mail going out of the village was censored by the village Party secretary or a designated representative on the Party Chapter Committee, and mail from

33. DT-108, p. 50.

34. Vietnamese Communist Document 232, Dang Lao Dong directive, $p .1$.

35. DT-65, p. $12 . \quad$ 36. DT-61, p. 20. 
a military unit was censored by administrative personnel in the unit prior to dispatch. ${ }^{37}$

To compensate for the loss of non-Party sources of information, the Dang Lao Dong provided a new frame of references for the peasant. Authorized radio stations were Radio Hanoi, Radio Peking, and the National Liberation Front station, which was purported to be set up in the "liberated zone" of South Viet-Nam..$^{38}$ Printed matter distributed by the Party in Dinh Tuong included a monthly periodical entitled $A p$ Bac (named after the scene of a Party victory in northern Dinh Tuong), a monthly newspaper entitled Nhan Dan ("The People"), and an occasional paper named Trung Lap ("Neutralism"), which was published in Cambodia..$^{39}$

The Party further isolated the peasants in the "liberated" villages by creating new administrative units and renaming familiar landmarks. Hoa Dinh village, Cho Gao District, had been composed of seven hamlets, but after it gained control of the area, the Dang Lao Dong took two hamlets from two neighboring villages and incorporated them into Hoa Dinh. Thus, as one native of Hoa Dinh remarked, for those on the side of the South Vietnamese Government, Hoa Dinh had seven hamlets, and "for the Front, Hoa Dinh had nine hamlets." ${ }^{0}$ In Long Dinh District, a canal long known as Kinh Xang was renamed Nguyen Tan Thanh in honor of a deceased Party member. ${ }^{41}$ Such changes created a situation in which a peasant from a Government area and one from a "liberated" village could find little that their neighboring worlds had in common. The Dang Lao Dong's success in creating at least a partial rift in the world view of the population in Dinh Tuong is reflected in former Party members' references to Government areas as "outside" or "out here" and to the "liberated" base zones as "in there." 42

37. Rand Corporation and MACV J-2, File No. DT-107 (II), Studies of the National Liberation Front of South Vietnam, pp. 2-12 passim. Cited hereafter as DT-107.

38. DT-65, p. 12.

39. Rand Corporation and MACV J-2, File No. DT-96 (I), Studies of the National Liberation Front of South Vietnam, p. 13. Cited hereafter as DT- 96 .

40. DT-84, p. 1. 41. DT-86, p. 6.

42. Rand Corporation and MACV J-2, File No. DT-73, Studies of the National Liberation Front of South Vietnam, p. 4; Rand 
Restriction of Movement. The Dang Lao Dong limited the peasants' freedom to travel in order to deny manpower to the South Vietnamese Government and, more importantly, to keep the population, upon whose support the revolutionary movement depended, under Party control. Toward these ends, the Dang Lao Dong implemented stringent measures.

The most versatile tool used by the Party to keep the peasant in his village was the land. When a villager left the village and resettled in a Government area, the village Party Chapter sent two notices through relatives warning the refugee that if he did not return, his land would be confiscated. If he did not heed a third notice, the Party seized the land and parceled it out to families whose sons either had regrouped to North Viet-Nam in 1954 or were serving the National Liberation Front. ${ }^{48}$ If the dispossessed farmer remained in the Government area, his relatives were prohibited from leaving the village.4 The Party also confiscated land owned by families whose sons joined the South Vietnamese Army, relinquishing it only if the sons returned to the village. This practice, in addition to restricting movement, simultaneously reinforced the desertion campaign waged by the military proselyting section. 45

If a family who had a son serving in the South Vietnamese Government owned no land, the Dang Lao Dong used other means to make him return home. One young man who was residing in a Government-controlled village in Dinh Tuong was sent a notice to return home for duty in the Du Kich. When he refused, his father was forced to attend "re-education" sessions. Such sessions, as previously mentioned, deliberately placed the victim in danger of death and entailed extreme hardship. The fathers of such sons were required to furnish their own rice, mosquito nets, and shovels for digging shelter-holes in which they slept. After ten days of such treatment, they were offered the opportunity to write their sons a note, asking them to return. If they refused to

Corporation and MACV J-2, File No. DT-92, Studies of the National Liberation Front of South Vietnam, p. 9; DT-101, p. 56.

43. DT-75, p. 11.

45. DT-79, p. 2.

44. DT-86, p. 22. 
write or their sons refused to return, "re-education" was continued. ${ }^{46}$

Movement for any purpose outside the village was carefully regulated by the military affairs section, which issued movement passes for those having to leave the village. Such passes described the carrier, stated the purpose and destination of his trip, and noted the expiration date of the pass itself. ${ }^{47}$ The traveler turned in the pass to a liaison station at his destination. "Trustworthy elements" or "true comrades" received permits good for six months, whereas the "suspect elements" who did manage to obtain passes found that they had to renew them more often and, in addition, that they were limited to certain routes to their destination. Only the "trustworthy" elements were permitted to travel to Government areas after filing a travel plan that specified travel times and destination. Any deviation in either time or itinerary required a full explanation on return. ${ }^{48}$

To discourage travel out of the village even further, some Party secretaries adopted the policy of punishing persons who were away from home when the village was bombarded by the Government. ${ }^{49}$ Nor could the travelers be certain that they would be received: Villagers remaining in the village had to apply to the military affairs section for permission to receive relatives, and only those relatives who, after investigation, were classified as "desirable elements" were permitted to enter the village. ${ }^{50}$ Those villagers who attempted to seize the opportunity of a Government military operation in the area to leave home also faced great risks. In one case, the village Party secretary in My Loi village, Giao Duc District, ordered the Du Kich to filter in among the refugees and fire on aircraft covering the operation. The aircraft returned the fire, driving the people back into the village and killing many in the process. ${ }^{51}$

Such coercive measures, while generally effective, nonetheless had drawbacks. A Party document described several

46. DT-85, p. 12.

47. Vietnamese Communist Document 18, Travel permit, p. 1.

48. Davison, Observations, pp. 123-25.

49. DT-63, pp. 6-7.

50. DT-86, p. 4.

51. DT-101, p. 31 . 


\section{THE VILLAGE WAR}

incidents in which authoritarian control worked against the Dang Lao Dong. One peasant whose younger brother had joined the South Vietnamese Army was deprived of his land when the brother refused to come home. The peasant himself then enlisted in the Government forces, where, the Party reporter lamented, "he is now spreading defamatory stories about us." The document also mentioned that other persons who had been deprived of their land moved away from their villages and came back to the village as Government cadre to eliminate the Party network. ${ }^{52}$

Under such conditions, it was not surprising that one respondent mentioned the freedom to travel as he pleased as the greatest single benefit of Party membership, ${ }^{53}$ or that a villager, after being under the Party's movement control and later escaping to Saigon, mentioned that he enjoyed most the freedom to move about whenever he wished. ${ }^{54}$

Labor Exchange. In two separate areas of Dinh Tuong, the Dang Lao Dong initiated changes in the traditional Vietnamese economic pattern that were designed to prepare the peasants for complete Party control over the rural economy. In Cho Gao and Cai Be districts, the Farmers' Liberation Association began organizing the village farmers into To Doi Cong ("Labor Exchange Squads"), which one Party official described as a "way of training the farmers and making them get used to the way of life of the co-operative of the future." 55

The Labor Exchange Squads were first established in Hoa Dinh village, Cho Gao District, in June 1964, and in Cai Be District's Hau My village in 1965. In Hoa Dinh, the Labor Exchange Squads included the following specialized groups: the Cong Trau ("Buffalo Group"), the Nhom Cong Lam ("Odd Job Group"), and the Nhom Cong Cay Gat ("Planting and Harvesting Group"). The Buffalo Group was composed of all owners of water buffalo; the owner of the buffalo received VN\$100 per day for each buffalo. Members of the Odd Job Group weeded fields, broke up earth after

52. Vietnamese Communist Document 749, Report on Dang Lao Dong land policies in the Mekong Delta, p. 20.

53. DT-61, p. 6.

55. DT-108, p. 72.

54. DT-88, p. 10. 
plowing, and prepared fields for planting. Each laborer received VN $\$ 4^{\circ}$ per day, whereas hired laborers outside the system received VN\$45 per day. In the Planting and Harvesting Group, all of whom were women, each worker received wages amounting to $\mathrm{VN} \$ 35$ per day. ${ }^{56}$ In Cai $\mathrm{Be}$, the Party did not limit the exchange of labor to farm workers; village shopkeepers were required to sell their goods according to a price index, and medical practitioners were paid a salary instead of collecting fees from patients. ${ }^{57}$ The absence of any mention of the Party's instituting labor exchange practices in other areas of Dinh Tuong in the years 1960 to 1964 indicates that this development was in its formative stages toward the end of 1964 .

Enforcement Terror. As defined by Thornton, enforcement terror consists of violent acts perpetrated by an incumbent authority in order to create an atmosphere of fear among the population that the authority dominates. ${ }^{58}$ This kind of terror substantially helped the Dang Lao Dong gain a firmer grasp on the population. Unlike the agitational or disruptive terror of the psychological offensive, which was committed by specialized Party elements, participation in enforcement terror spread beyond the Party and into the various Liberation associations, which assumed a crucial role in making violence acceptable to the people.

The chief instrument by which enforcement terror was dispensed was the People's Court. As one Party member explained, the role of the masses was not to act but, rather, to witness the actions of Party members operating under the guise of the National Liberation Front. The decisions about guilt and the kind of punishment were made by the Party beforehand. If the victim was to be killed, the Party designated twelve members of the mass organizations to demand the death penalty and eight to ask for clemency. If the Party did not deem death appropriate, the proportions were reversed, and the majority of the backbone elements asked for a lesser penalty. ${ }^{59} \mathrm{~A}$ witness's account of a People's Court in 56. Ibid. 57. DT-64, p. 8.

58. Thomas Perry Thornton, "Terror as a Weapon of Political Agitation," in Internal War, ed. by Harry Eckstein, p. 72.

59. DT-108, pp. 22-23. 


\section{THE VILLAGE WAR}

action captures the interplay between the Party and the Liberation associations:

When the villagers were gathered, $\mathrm{Ba}$ Phuoc [the village Party secretary] read the dossier of the culprit and the Front's accusations. The villagers were then asked to give the verdict. The background elements demanded that the culprit should be killed. The village secretary confirmed the people's sentence by stating that the culprit was a bad man. A representative of the Liberation Youth Association confirmed the village secretary's opinion and finally, a representative of the Farmers' Association stood up to declare that the culprit deserved the death sentence that the people were demanding. When all this was over, Xanh was shot although his wife and his children tearfully pleaded for clemency. I noticed that, in fact, the families which supported the Front were eager to have Xanh sentenced to death, and their loud accusations had heated up the atmosphere of the meeting. ${ }^{60}$

In the rare instances when the unorganized villagers did exert enough pressure to thwart the Party's desires, the Dang Lao Dong managed to by-pass the obstruction by sending the victims out of the village, ostensibly for "re-education" or further questioning, and liquidating them in an isolated area. ${ }^{61}$

Internal Party Controls. Although Party members were free from the travel restrictions imposed on village inhabitants and members of the mass organizations, they were subject to other severe and more sophisticated controls. Defection from Party ranks rated immediate confiscation of land if the individual did not return after due warning. ${ }^{62}$ Party members were warned that defectors who refused to return and who assisted the South Vietnamese Government in any way would be tracked down and executed. ${ }^{63}$

More subtle measures were taken against those members who refused to conform to Party discipline or to accept decisions from higher echelons. As one Party official explained, he first used the "force of the majority" to place pressure on

6o. DT-107, p. 23.

61. DT-85, p. 9.

62. DT-79, p. 20.

63. DT-65, p. 14; DT-79, p. 20. 
the recalcitrant member or members. If this failed, the Party simply cut off all relations with the dissidents, "rescinding all missions with which they were entrusted and leaving them alone." In a nation in which revolution had drawn battle lines between two disparate worlds, the Party member deprived of support was a man in a spiritual vacuum and in physical danger. Persons sent to Coventry, according to the Party member, could not bear it for more than a month. "They were ashamed and sad," the source recounted, "and at last, they had to ask to cooperate with us." 64

The most effective internal control measure within the party was kiem thao ("criticism-self-criticism session"). Ostensibly, the purpose of kiem thao was to correct errors committed in Party work. By way of making disclosure of personal errors less distasteful, Ho Chi Minh assured the Dang Lao Dong rank and file that mistakes were the natural result of struggle. Nonetheless, Ho cautioned, failure to admit mistakes was "like a patient who refuses to tell his disease to the doctor." ${ }^{n 5}$ Self-criticism produced a state of constant introspection within each individual in the search for his own mistakes and errors. Criticism, alternatively, was the motivation for self-criticism, for if the individual did not seriously analyze his own faults in the presence of his coworkers during self-criticism, he was sure to be subjected to denouncement. ${ }^{66}$ On the other hand, his failure to criticize others did not exempt him from being accused of obstructionism and lack of revolutionary fervor. The mutual aggressiveness was fueled by mistrust. ${ }^{67}$

Within the Party, kiem thao was held each day in the Party cells and less often in larger groups. ${ }^{68}$ In the sessions, rank had no privilege, and superiors were as subject to criticism as subordinates. The topics most frequently discussed in kiem thao were negligence of combat duties, "wrong thought," authoritarian attitudes toward the population, and illicit sexual affairs. ${ }^{69}$ Sexual promiscuity was dealt with

64. DT-61, pp. 4-5.

65. Ho Chi Minh, Ho Chi Minh on Revolution: Selected Writings, 1920-1966, ed. by Bernard B. Fall, p. 186.

66. Singer, Control of Population, p. 68.

67. Conley, Communist Insurgent Infrastructure, pp. 221-22.

68. DT-85, p. 28.

69. DT-49, p. 18. 
harshly, and the punishment could range from severe criticism in kiem thao to relief from the Party. ${ }^{70}$

The practice of kiem thao was well received by most of the higher-ranked cadre, but looked upon with distaste by the lower ranks. Three long-time Party members agreed that the rank and file disliked kiem thao because it "curtailed their freedom" and hurt their pride. ${ }^{71}$ One of the three stated that he personally favored kiem thao because it made it possible to determine the thoughts of the lower echelons. ${ }^{72}$ Another expressed his approval of kiem thao because it eased the commander's problems by reminding the cadre and members of the Du Kich to behave correctly among the population. ${ }^{73}$ One lower-ranking member of the Du Kich expressed the outlook generally prevalent among his peers when he said that he disliked kiem thao because he was afraid of being criticized. No one, the source reported, "escaped criticism." "74

\section{Village Revolutionary Activities}

At this point, the Party had set the stage for commitment of the village to the struggle to destroy the South Vietnamese Government. The village population was thoroughly enmeshed in the interlocking Liberation associations and their special-interest groups. The villagers were supporting the National Liberation Front through their taxes and by membership in the village paramilitary forces. Mutual and organizational surveillance, combined with enforcement terror, ensured compliance with the program of the Party to create a regimented society. The Dang Lao Dong was able to control its own members closely and to recruit replacements from the mass organizations. All that remained was to direct the sum of these forces in the revolutionary movement.

The Struggle Movement. The dau tranh chinh tri ("political struggle movement") under which the Dang Lao Dong grouped the dich van, binh van, and dan van programs offered the Party the opportunity to employ the mobilized

70. DT-65, pp. 10-11; DT-85, p. 20.

71. DT-85, p. 28; DT-96, p. 12; DT-99, p. 26.

72. DT-96, p. 12.

73. DT-85, p. 29.

74. DT-55, p. 9. 
village population in a direct attack upon the South Vietnamese Government. The particular mechanism for the direct involvement of the population was called the dau tranh truc dien ("face-to-face struggle"), a form of political activity that Nguyen Huu Tho, Chairman of the National Liberation Front, described as "coordinating political with military struggle." 75

The first step in organizing a face-to-face confrontation with the Government authorities was to conduct a mass meeting in order to create an atmosphere of excitement. Prior to the meeting, the Party chose the subject for denouncement and made assignments for the major speaker, for slogan-shouters from the Liberation associations, and for those who were to come forward "spontaneously" to endorse the speaker's remarks. ${ }^{76}$ The preparations of the propaganda section reveal a shrewd pragmatic approach to staging mass meetings. Only one topic received the full attention of the Party and the Liberation associations, because discussing many grievances would dissipate energy. In the rare event that the Party decided to hold a mass meeting to arouse the people's ire regarding two subjects, a policy decision was made beforehand to determine the more important topic. The backbone elements were then assigned proportional agitational roles, the majority being ordered to support the major topic and the rest the secondary issue. ${ }^{77}$

The main speaker, often the Party secretary or another Party member noted for his oratorical ability, started the meeting by haranguing the crowd, stimulating them with revolutionary rhetoric. At the end of his speech, the backbone elements, picking up their cue, began to shout slogans. Persons from the crowd then came forward with stories of personal misfortunes attributed to the South Vietnamese Government, and again the slogan-shouters stirred the crowd. ${ }^{78}$

The second step, the execution of the face-to-face struggle, was carried out when emotions were at their peak. A crowd of old people, women, and children, with attendant buffalo and pigs, would converge upon the district head-

75. Wilfred G. Burchett, Vietnam: Inside Story of the Guerrilla War, p. 63 .

76. VCD 130, p. 137.

78. VCD 130 , p. 38 .

77. VCD 737, p. 21. 
quarters of the South Vietnamese Government, paralyze traffic, and ask to speak with the district chief. If granted an audience, the group spokesman would ask that the peasants be protected from the cruel landlords or that the Government cease drafting young men to fight in a fratricidal war. ${ }^{79}$ Other themes used in face-to-face struggles were requests that the Government not fire artillery shells near the village or that the Government discipline soldiers who had misbehaved in the village. ${ }^{80}$ Such actions invariably placed the South Vietnamese Government in a bad light, discomfiting district officials and appealing to the villagers' innate sense of humor at having embarrassed a Saigon official.

While the struggle movement was being conducted, covert propaganda section cadre noted the performance of the participants. Once all were back in the village, the village Party secretary congratulated those who had shown energy and enthusiasm and criticized the rest, advising them to emulate the fervor of the ones who had done well. ${ }^{81}$ Those villagers who refused to participate in the face-to-face struggles were placed under house arrest, a punishment that prevented them from working their fields. ${ }^{82}$

The earliest recorded face-to-face struggle in South Viet-Nam took place in Dinh Tuong Province's Chau Thanh District in 1960.83 From that time until the end of 1964, the Dang Lao Dong claimed credit for nineteen "major" face-toface struggles in Dinh Tuong; according to Party publicists, those struggles had involved a total of a quarter of a million persons. ${ }^{84}$ Besides using the villagers in the face-to-face struggle, which placed them in direct opposition to the South Vietnamese Government, the Dang Lao Dong drew upon the village to help with supply and communications systems and to provide manpower for the Party's regular military forces.

Village Supply and Communications Activities. Supplies brought into Dinh Tuong for the regular military units were stored by the village Party Committees in "strong" villages

79. Burchett, Vietnam, p. 63 .

81. DT-61, p. 16.

8o. DT-49, p. 5 .

83. Pike, Viet Cong, p. 386.

84. Extracted from ibid., pp. $3^{88-93}$. 
until the Local Forces or Main Forces needed them..$^{85}$ Once transported to the village, the supplies were stored in caches constructed by the military affairs section. The locations of the caches were known only to the military affairs chief and the village Party secretary ${ }^{86}$ When regular units needed ammunition for a battle, they sent requisitions to the military affairs section, which ordered porters from the Liberation associations to move the supplies to predesignated pickup points. ${ }^{87}$

When on the move, units of the Local Forces and Main . Forces generally preferred to stay the nights in the homes of the villagers, rather than bivouacing in the field. ${ }^{88}$ Before it entered a village, the military unit was required to send a liaison team ahead to obtain the permission of the Party secretary, who then made the necessary arrangements for supplying food and other necessities. ${ }^{89}$ The regular units of the National Liberation Front received funds for travel expenses, which varied from district to district within Dinh Tuong according to the local cost of living. The rate was approximately seven or eight piasters per day. ${ }^{90}$ Troops took their meals with the families who housed them, paying for the meals with their travel funds. In contrast to the many references to the chicken-stealing proclivities of soldiers in the South Vietnamese Army, no mention was found of any widespread misbehavior on the part of the NLF military or paramilitary forces, in spite of the opportunities for mischief provided by quartering soldiers in private homes.

As the Party took over more villages and denied the peasants access to the Government-controlled markets, acquisition of fertilizers and pesticides that had been used to increase rice production for over twenty years became correspondingly difficult. ${ }^{91}$ As a consequence, the rice yield in some villages began to drop. In areas where rice was in short supply, advance preparations were made through adjacent

85. DT-101, p. 50.

87. DT-101, p. 50.

89. DT-49, p. 24.

90. DT-58, p. 15; Rand Corporation and MACV J-2, File No. DT-103 (II), Studies of the National Liberation Front of South Vietnam, p. 4 (Cited hereafter as DT-103).

91. Gerald C. Hickey, Village in Vietnam, p. 139. 
village Party chapters to supplement rice stocks in villages where the regular units spent the night. ${ }^{22}$

In addition to storing of food and ammunition and providing shelter for the military units, the village supplied medical services when an engagement with South Vietnamese Government troops was to take place in the vicinity. Crude but effective field hospitals were established in designated homes, where facilities for first aid and surgical treatment were set up. These hospitals were constructed in such a way that they could be dismantled and hidden within a matter of minutes if Government forces threatened to enter the village. ${ }^{93}$ Along with establishing medical-care facilities, the Party secretary worked through his civil affairs section, which controlled the Liberation associations, to have quantities of coffins built and graves dug, thus ensuring that the dead could be buried a short time after the battle. ${ }^{94}$

The Party chapters in the "strong" villages also maintained liaison stations that provided communications between the military units and the villages and, before the massive introduction of two-way radios in 1964, transmitted messages of a purely military nature between the combat units. Couriers between the private homes that served as village stations were often young boys and girls who, riding bicycles or traveling on foot, carried approximately twelve pounds of letters and messages in each load..$^{95}$ Members of the Foster Mothers' Association staffed the he thong giao lien ("liaison system"). In addition to sending mail and official Party communications, the staff authenticated letters of introduction and arranged the necessary contacts for escorting travelers to the next liaison station. In effect, the system was an "underground railroad." 96

As might be expected, having to depend on the villages for provisions and communications restricted the movement pattern of units in the Local and Main Forces. A member of the 261st Battalion, a Main-Force unit, asserted that every time the battalion moved through Dinh Tuong Province, it stayed in the same villages. ${ }^{27}$ Another source claimed that it
92. DT-85, p. 20.
94. DT-107, p. 12.
93. DT-96, p. 5.
96. Conley, Communist Insurgent Infrastructure, p. 40.
97. DT-101, p. 51.
95. Ibid., p. 17. 
was part of the doctrine of the regular military forces to move only in the areas controlled by the Party and to venture out only when they received orders to launch a lightning raid or an attack. ${ }^{98}$

Manpower Support. Mao Tse-tung, analyzing the question of centralized versus decentralized control of revolutionary warfare, wrote in 1938 that, given the large areas of operations, complex local situations, and difficulty of communications from higher to lower levels, it was more advisable to permit greater independence to lower levels and to allow actual operations to assume a character "conforming more closely to the local requirements." This autonomy was needed, Mao concluded, so that lower-level leaders could develop the ability to work independently and to cope with complicated situations. ${ }^{99}$ No single aspect of village Party operations better illustrates the adoption of this principle of decentralized control and local autonomy than the Party's arrangement for the provision of manpower to the military struggle.

Rather than being an automaton in a monolithic organization-a role implied in the pejorative "faceless Viet Cong," which has been applied to the Dang Lao Dong-the village Party secretary had a surprising amount of leeway in his bailiwick. ${ }^{100}$ Part of the foundation of a village's autonomy within the Party's organization rested on the role of the Party secretary as the commander of the Du Kich. As such, he was not subordinate to leaders of the regular military units, and one village's chief of military affairs claimed that when the Party needed the combat guerrillas to augment a larger military operation, the village Party secretary could, if he did not approve of the operation, withhold the use of his forces. ${ }^{101}$

Testimony from Party members indicates that the Party may have started to move toward a more centralized form of control by the end of 1964 . One respondent testified that the

98. DT-80, p. 25.

99. Mao Tse-tung, Selected Military Writings of Mao Tsetung, pp. $184-85$.

100. George A. Carver, Jr., "The Faceless Viet Cong," Foreign Affairs, 44 (April, 1966), 347-72.

101. DT-86, p. 8. 
successes of the Dang Lao Dong in Dinh Tuong were permitting the consolidation of more areas. When the Party was strong enough to establish a Liberation committee, rather than a Party Chapter, in an area, it eliminated the military affairs section and delegated the functions of that section to an element called the $x a$ doi ("village unit"). This change signified the regularization of the Du Kich within the regular military hierarchy ${ }^{102}$ and marked the end of the necessity for operational independence of the village Party secretary.

During the period 1960 to 1964 , the Party used manpower from the villages to fill out the Local Forces and Main Forces by direct conscription from among the village youth and by promotion of experienced members of the Du Kich into the ranks of the regular military forces. Promotion from the $\mathrm{Du}$ Kich was the traditionally preferred path by which the Dang Lao Dong built its military forces. The village Party Chapter was levied for combat guerrillas to be sent to the regular units by the district Party Chapter Committee, and the village Party secretary had the authority to name those who would be sent. ${ }^{103}$ Ideally, the best-qualified combat guerrillas were sent to the Local and Main Forces. In 1960, the 261st Main Force Battalion was made up entirely of veterans who had come up through the Du Kich and the Local Forces. ${ }^{104}$

In the years that followed 1960, two factors worked against the ideal model for building an army. First, the village Party secretaries, as commanders in their own right, were not above sending their troublemakers up to the Local and Main Forces and keeping the best men in the Du Kich. ${ }^{105}$ Since the military commanders exercised no authority over the village Party secretaries, they could not stop this practice. ${ }^{106}$ Second, as the pitch of combat increased and casualties mounted among the regular forces, replacements had to be drawn from the Du Kich before they were effectively trained. In some cases in 1964, young men spent as short a time as one day in the $\mathrm{Du}$ Kich before being posted by the

102. DT-108, p. 42.

104. DT-85, p. 23.

103. DT-55, p. 5 .

105. DT-101, p. 43.

106. Conley, Communist Insurgent Infrastructure, p. 92. 
village Party secretary to a unit of the Local or Main Forces. ${ }^{107}$

Although as early as 1960 the Dang Lao Dong promulgated a conscription policy that called for all males between the ages of 18 and 35 to serve three years of active duty, ${ }^{108}$ the Party did not start drafting men into its regular units until later. Before 1963, the Party stronghold of Cai Lay District had enough volunteers to fill quotas for its Local and Main Forces, but during that year, the Party used methods of conscription reminiscent of the press gangs in eighteenthcentury England. Enforcement terror was applied to suppress initial dissent against the draft. In one village, the first two men to oppose the draft were tied and summarily shot in view of the inhabitants. After this, a witness recounted, "nobody dared protest any longer." ${ }^{109}$ In other villages, armed parties made halfhearted attempts to persuade young men to volunteer and, failing, immediately tied them and marched them off to isolated training areas. ${ }^{110}$

In the matter of conscription, as in so many other areas, the village Party secretary was the individual who decided the means to be used in his village. One former secretary of a "temporarily liberated" village rejected the use of forceful conscription because he deemed Party control to be too weak. This policy was adopted and maintained in the face of pressure from the district Party Committee to use force in order to meet the manpower demands of the regular military units. ${ }^{111}$ In addition to common force, the village Party secretary had at his disposal less objectionable means. "Reeducation" was frequently used, because the incarceration of wives, mothers, and fathers in primitive "re-education centers" proved to be effective in bringing draft-dodgers

107. Rand Corporation and MACV J-2, File No. DT-102 (I), Studies of the National Liberation Front of South Vietnam, p. 4 . 108. DT-101, p. 34.

109. Rand Corporation and MACV J-2, File No. DT-98 (II), Studies of the National Liberation Front of South Vietnam, p. 7. Cited hereafter as DT-g8.

110. Rand Corporation and MACV J-2, File No. DT-104 (I), Studies of the National Liberation Front of South Vietnam, p. 4; DT-94, p. 2.

111. DT-99, p. 14. 
home from their sanctuaries. ${ }^{112}$ Another technique, referred to by the Party as ba mat doan the hoc tap ("indoctrination by the three associations"), involved the exertion of social pressure on youth by the three major Liberation associations. One Party member described such an indoctrination process:

We relied on the members of the Farmers' Association, Women's Association, and the Youth Association to put pressure on them. We invited their fathers, who must be members of the Farmers' Associations, and their mothers or wives who must be members of the Women's Association to attend educational courses. We made them thoroughly understand Front policy and the youth's duty and urged them to exhort the youths to volunteer. ${ }^{113}$

The military proselyting section of a Party Chapter, upon learning that a villager in a "contested" village had received a call-up notice for the South Vietnamese military forces, called upon the prospective draftee and attempted to convince him that he would be better off in the National Liberation Front forces. ${ }^{114}$ The primary appeal of the Front was that service in the South Vietnamese Army would probably send the villager far from his home province, whereas he stood a better chance of remaining near his family in a Local or Main Force unit. As was the case in so many of the Party's personnel policies, a man's assignment was influenced greatly by his background. A draftee who had relatives serving the South Vietnamese Government was sent farther away from home than one who had an unblemished background. ${ }^{115}$

The fortunes of the Dang Lao Dong military units fluctuated during the period 1960 to 1964 in proportion to the ability of the villages to provide manpower. From 1960 to 1962, the regular units in Dinh Tuong encountered few serious problems in this respect, volunteers being sufficient to meet their needs. ${ }^{116}$ One old-time Party member recalled that the years 1960,1961 , and 1962 were "very good years" for quality soldiers-morale was high, the young men of the

112. DT-103, p. 5 .

114. DT-86, p. 2.

116. DT-98, p. 7 .
113. DT-61, p. 13.

115. DT-8o, p. 3. 
villages were courageous in combat, and desertions were rare. ${ }^{117}$ The men who did leave the forces left because of homesickness or to get the crops in, and they soon returned to their units, a pattern similar to that of Washington's troops in the Revolutionary War. In 1963, according to a member of the 261st Battalion, desertions began and, chiefly because of the increased severity of combat operations, grew to the point that toward the end of 1964 , as many as nine men at a time were leaving. The companies of the 261 st, which had originally contained 120 men, were down to an average strength of 80 persons. ${ }^{118}$

Many of these desertions were "internal," as were many desertions from the South Vietnamese Army: the deserter did not go over to the opposing side; he simply went home, opting out of the war. Since the commander of a regular Communist military unit did not control what went on inside the villages in his area, it was up to the village Party secretaries to take some action when the deserters showed up in their home villages. The battalion or regimental commander had to content himself with sending a report back through the liaison network, notifying the village Party Chapter of the names of the deserters. ${ }^{119}$

In some cases, deserters, after being criticized publicly by the gathered Liberation associations, agreed to return to their units. ${ }^{120}$ However, in Vinh Kim village, Long Dinh District, seventeen young men who deserted en masse in 1964 returned to their homes and withstood the application of public criticism by the associations and the "re-education" of the parents. The village Party secretary apparently decided that use of force against the group would not be wise and adopted the policy of isolation of the youths, a tactic that neither pleased the district Party Committee nor served to force the deserters to return to the fold. ${ }^{121}$ Another deserter returned to his village, and the Party secretary, taking note of the man's ability while choosing to overlook his disloyalty, finally capitulated and not only permitted him to remain at home but elevated him to the position of chief of the military affairs section. ${ }^{122}$ The most serious case of desertions was re-

117. DT-101, pp. $35-36$.

119. DT-58, p. 16.

121. DT-99, p. 14.
118. Ibid., p. 36 .

120. DT-65, p. 16.

122. DT-86, p. 17. 
ported in Cho Gao District where, in early 1964, nearly 240 youths from one village alone deserted the military forces. ${ }^{123}$

In spite of the problems of desertion, the military power of the National Liberation Front continued to grow in Dinh Tuong Province. Comprised of the 514th and 261st Battalions in 1963, the Main Forces began funneling new recruits and draftees into the 514th Battalion in early 1964. A nucleus of experienced cadre and new soldiers was formed within the battalion, and a platoon of approximately 40 men was designated the $265^{\text {th }}$ Battalion. This platoon, under the shelter and tutelage of the combat-hardened 514th, grew in numbers to a company of 120 men. By June 1964, the villages had provided enough personnel to make the $265^{\text {th }}$ a full battalion of nearly 500 men. At that time, it was declared an independent battalion and moved to conduct operations in neighboring Kien Hoa Province, as well as Dinh Tuong. ${ }^{124}$

Behind the screen provided by the military arm of the Dang Lao Dong, the influence of the Party seeped from the "strong" to the "weak" areas, and the number of villages that came under Party control rapidly increased. By 1965, the Dang Lao Dong, leminence grise of the National Liberation Front, controlled over 60 per cent of Dinh Tuong Province. ${ }^{125}$

123. DT-108, p. 8. 124. DT-80, p. 3.

125. Edward J. Mitchell, Inequality and Insurgency: A Statistical Study of South Vietnam, Table 1. 
It's rather like bridge as compared to belote.

When we make war, we play belote with thirty-two cards

in the pack. But their game is bridge and they have

fitty-two cards: twenty more than we do. Those twenty

cards short will always prevent us from getting the

better of them. They've got nothing to do with

traditional warfare, they're marked with the sign of

politics, propaganda, faith, agrarian reform.

-Jean Lartéguy, The Centurions

\section{THE PATTERN OF}

\section{REVOLUTIONARY ACTION}

The pattern of revolutionary warfare that emerges is clear. From the beginning, the Dang Lao Dong was the dominant force behind the struggle in Dinh Tuong Province, its paramountcy cloaked by the façade of a united front, the National Front for the Liberation of South Viet-Nam. Working with the NLF as a cover, the Party destroyed the traditional references in the rural villages and substituted new sociopolitical supports that were manipulated by the Party for the Party's own purposes.

Party operations in Dinh Tuong were muted until 19591960. Between 1954 and the "rising" of the Party, the Dang Lao Dong strengthened its clandestine organizations in the villages, relying to some degree on former members of the Viet Minh who had gone underground after the 1954 ceasefire agreements. Concurrently, the Party established secret enclaves in remote areas, such as the Plain of Reeds in northern Dinh Tuong.

In 1959 and 1960, the Dang Lao Dong began to eliminate the non-Communist village leaders. Assassination, kid- 


\section{THE VILLAGE WAR}

napping, mutilation, and intimidation were all included in the Destruction of the Oppression, and less-violent means, including public humiliation, were used in the Reduction of Prestige campaign. Although assassination and denigration of character continued in Dinh Tuong throughout the period examined, it appears that the broad use of these destructive instruments ceased after 1963 . The only resistance of note to the Dang Lao Dong's repression came from villages that were predominantly Catholic or Cao Dai.

During its expansion in the villages, the Party emphasized the building of such mass organizations as the Farmers', Women's, and Youth Liberation Associations, which, controlled by Party cadre, served to insulate the non-Communist villager from the South Vietnamese Government and thus to make him available for further indoctrination and manipulation by the Dang Lao Dong. Land "reform" was begun, and a comprehensive taxation system was established.

As the Party grew in numbers, its own organization in the village was refined and made more sophisticated in order to direct the mass organizations and to control the population more effectively. The Party, nonetheless, remained an elite organization that influenced the activities of the peasantry through social pressures brought to bear by the mass organizations and occasional terrorist actions.

Consolidation, a process begun in much of Dinh Tuong by 1964, was marked by an increasingly active role in support of the Party by villages that had been successfully penetrated by the Dang Lao Dong. The peasantry became engaged in political or military activity against the South Vietnamese Government; surveillance, both mutual and organizational, of the population was established; information was controlled and altered; and the peasants' freedom to travel was seriously circumscribed. The collectivization process began with the initiation of labor exchange groups, and terror, formerly used to disrupt the Government of Saigon, was selectively used to enforce the policies of the Dang Lao Dong.

The struggle in Dinh Tuong, as it was elsewhere in South Viet-Nam, was the by-product of the Dang Lao Dong's efforts to tear down the existing society and erect a new one, one in which the Party would reign supreme. The essence of 


\section{PATTERNOF ACTION}

the struggle can best be grasped by a discussion of the most significant aspects of the Party's activities in Dinh Tuong Province, namely, the implications and ramifications of the Destruction of the Oppression and Reduction of Prestige campaigns, the point at which the Dang Lao Dong ceased acting as a conspiratorial organization and began to function as a legitimate government, and the difference between the revolutionary goals of the non-Party peasantry and those goals envisioned by the Dang Lao Dong.

The Dang Lao Dong benefited from the Destruction of the Oppression and Reduction of Prestige campaigns by the elimination of those village leaders who stood in the way of the Party and by the creation of a high degree of social disorientation among the village population.

The authority of the South Vietnamese Government in Dinh Tuong rested, as does the authority of any government, on the legitimacy of its claim to represent the community and to act in the community's best interests. This legitimacy, in turn, was derived from the population, who perceived the ruling elite as capable of providing practical solutions for problems confronting the village. The elimination of local leaders by assassination in the Destruction of the Oppression or by public humiliation in the Reduction of Prestige worked to erode the authority of the South Vietnamese Government. The terror campaigns of the Dang Lao Dong represented a direct challenge to the South Vietnamese Government, each successive act increasing internal Party morale and creating a popular myth of the Dang Lao Dong's invincibility. By their success in eliminating leaders loyal to Saigon, the Dang Lao Dong very persuasively demonstrated the weakness of the South Vietnamese Government. Indeed, through poorly conceived propaganda attempts, the South Vietnamese and their U.S. advisors aided the Party by publicizing its acts of terror.

The vulnerability of any group to disruption by terror hinges on the strength of organizational supports available to the individuals comprising the society-the extrapersonal references that provide security for the individual in times of stress. It is significant that both interrogation reports and captured documents mention that only the Catholic and Cao Dai communities were resistant to Party terror tactics. The 


\section{THE VILLAGE WAR}

Catholic or Cao Dai peasant's highly organized religion, with its vertical hierarchy, afforded the opportunity for individual integration into a large disciplined group that provided protection from disorientation and social isolation. The Confucianist or Buddhist had no strong organizational support to cling to. Both the Confucianist and Buddhist philosophies diametrically oppose Marxist doctrine, which emphasizes a nonfamilial concept of loyalty to higher authority. Philosophy alone, however, was not enough; organizationally, the Buddhists and Confucianists were limited to support from the extended family and could not, like the Catholics and Cao Dai, obtain assistance from larger groups that were connected to a vertical hierarchy. This organizational isolation, coupled with the tenets of filial piety, worked for the Party. Once the village leaders were eliminated, the village society tended to atomize into family groups that were then picked off one by one.

The destruction of the village social framework left the villager physically unharmed but socially isolated. His leaders had been proven incapable of surmounting the problems facing the village. The traditional behavioral norms to which the villager had been accustomed no longer assured a way to attain his goals. The peasant found himself alone in a threatening and chaotic world, and in order to save himself he had to find new answers that would offer stable frames of reference. Isolated and incapable of comprehending the nature of the problem facing him, no individual or his family group could define the necessary behavior patterns required to end the disorientation. It was at this point that the Party said, in effect, "Here, do these things and act in this manner and order will be restored."

The Party fitted itself into the Dinh Tuong village in such a way that the result was a symbiotic, rather than parasitic, relationship. The village became a source of support for the Party's revolution, and for the village, the Dang Lao Dong furnished leadership and organization. Into the turmoil resulting from the end of a traditional way of life, the Party promised a new order, a refuge for those buffeted by the forces unleashed by the fall of Imperial Viet-Nam and its French successors and, finally, of the Saigon Government's presence. 
This new order of the Party offered some comforting similarities to the traditional past, for the Dang Lao Dong realized, if Saigon did not, that traditional values and forms tend to persist during modernization. The village, once it was under firm control of the Dang Lao Dong, seemingly regained its old autonomous status, and within the village, the population was tightly knit against intrusion from the outside world. The mass organizations, controlled by the Party, offered a semblance of the old co-optative process of government while land redistribution harkened back to the Vietnamese tradition of village communal lands. After the terror and uncertainty, the Vietnamese peasant was willing to be re-bound to his village by a new set of social ties, ties devised by the Dang Lao Dong.

In his work Political Terror in Communist Systems, Alexander Dallin describes a "system of sanctions" required for the social and political control of a population. The system includes two kinds of power, "normative" and "coercive." Normative power encompasses social pressure, education, and the offer of prestige or recognition. It is the most economical and thorough means of control, but is inherently difficult to apply with discrimination. Coercive power uses such instruments as fines, regulations, penalties, police power, and terror. As opposed to normative power, the application of coercion can be more selective and is effective in obtaining short-term compliance, but it cannot ensure long-range positive commitment. ${ }^{1}$ The sanction system of a group aspiring to power through revolutionary violence is likely to consist largely of coercive power at the outset. This coercive power is directed toward the creation of an environment that will enable the revolutionary to rely increasingly upon normative power while reducing the use of coercion. When the revolutionary is able to successfully apply normative power, he can control a larger proportion of the target group with a very small core of the party faithful and, simultaneously, involve the population in the positive support of the revolutionary movement.

The activities of the Dang Lao Dong in Dinh Tuong Province from 1960 through 1964 indicate that the Party

1. Alexander Dallin and George W. Breslauer, Political Terror in Communist Systems, p. 2. 


\section{THE VILLAGE WAR}

began its operations by relying primarily on coercive power. The kind of support the Party demanded of the village population was the kind best produced by coercive power, namely, short-term compliance. The exercise of coercive power also brought the destruction of the vestigial traces of the normative power of the South Vietnamese Government. It was not until the Party began to function as a government in its own right that it utilized normative power to promote policies designed to involve the population in positive support of the revolutionary struggle. However, trying to move the peasants from compliance to commitment created serious problems for the Party, the nature of which was the subject of a Dang Lao Dong report quoted earlier:

Better to meet the enemy, which remained strong in the village, the Party began the elimination of influence of the village notables and local security agents.

However, it failed to follow this with the development of a mass base. The cadres thought that efforts to end the authority of the village leaders alone would be enough. ${ }^{2}$

The shift in emphasis from coercive to normative power in Dinh Tuong may be identified by examination of the changes in certain economic, organizational, and military policies of the Dang Lao Dong between 1960 and the end of 1964. The relationship between the easing of the Destruction of the Oppression and the implementation of the agricultural tax was a primary signal that the Party was making rapid progress toward assuming the form of a government. The Destruction of the Oppression was at its peak in 1963 and tapered off thereafter. In the immediate aftermath of the Destruction of the Oppression, the Dang Lao Dong ceased the haphazard practice of extorting "troop support gifts" and began systematic collection of agricultural taxes based on comparatively uniform tax schedules.

The acts of levying taxes and ending the Destruction of the Oppression reflected the Party's judgment that it had successfully eliminated the influence of the South Vietnamese Government and could begin to assume the role of legitimate authority in its place. Payment of the taxes, on the other hand, served as the taxpayers' acknowledgment of the Party's

2. VCD 2, p. 40. 
pre-eminent position. The accuracy of the Party's assessment of its position is confirmed by the amount of taxes collected during 1964 and by the Party's subsequent ability to direct that the taxes would be drastically increased in 1965 .

Organizationally, the Party's fortunes were on the rise in 1964. The formation of such mass organizations as the Farmers', Women's, and Youth Liberation Associations allowed the Party to use them as "transmission belts" that could, by using social pressure, ensure the peasants' compliance with Party directives. This use of normative power marked a departure from the use of naked violence that characterized the period from 1960 to 1964 . The existence of the mass organizations enabled the Party to begin to control the population in some areas through Liberation committees which included a number of non-Party members. The formation of these committees offers proof that the Party's control of the village population had, by 1964 , become quite firm and was in no danger from sources within the village.

Other organizational changes directed by the Dang Lao Dong presaged growing Party legitimacy in Dinh Tuong. One change was the formation of the Labor Exchange Squads in Cho Gao District in 1964 and in Cai Be District in early 1965. Such clear preparations for the collectivization of labor and land could not possibly have taken place if the Party had not thoroughly controlled the population in those areas. Also, as the Party gained political control, it withdrew the discretionary power of the village Party secretary to execute "enemies" and, in effect, retained this option at higher levels.

In the same year, increasing centralization was noticeable within the Dang Lao Dong's auxiliary, the Labor Youth Association. In 1960, village Labor Youth chapters were permitted to retain two-thirds of their dues for meeting local expenses. By 1964, the village chapters in Dinh Tuong were allowed to keep only one-third of the dues. Further, by that time the Party was able to establish Labor Youth chapters at the district level, whereas, in 1962, difficulties in recruitment and organization had limited formation to village level.

The Dang Lao Dong had formulated a policy for military conscription as early as 1960 but did not implement it until later. Only after the mass organizations had been established and the Party found itself securely in power was 
it able to begin drafting young men. The first conscription on a consistent basis seems to have occurred in 1963 in the Dinh Tuong district of Cai Lay-an area that had been largely under Party control since World War II. Military conscription appeared in the other districts of Dinh Tuong in 1964 . In spite of increasingly heavy combat losses and desertions, the Dang Lao Dong was able to draft enough men not only to make up shortages but also to increase the number of units in the Main Force.

In retrospect, it is evident that 1964 represented an important turning point for the Dang Lao Dong in Dinh Tuong. Before that year, the Party, relying heavily on coercive instruments, gained footholds in the villages at the expense of the village elites and the South Vietnamese Government. The abrupt decline of terror in 1964 was accompanied by implementation of taxation and conscription policies, organizational centralization, collectivization of labor, and the rise of the mass organizations-all indicators of a normativedominant system of sanctions that marked the emergence of a Party-controlled government. Until 1964, the South Vietnamese were faced with fighting revolutionaries; after that time, they were attempting to destroy a government.

One of the aspects of the struggle in Viet-Nam most puzzling to Western observers is that very few of those called Viet Cong-an abbreviation of Viet-Nam Cong San Dang ("Vietnamese Communist Party")-seem to be able to articulate their views of the war in classical Marxist terms. Often, in interviews, only a few prisoners or defectors measure up to the stereotyped definition of a Communist. Their lack of the typical rhetorical framework sometimes leads to the invalid conclusion that the revolutionary movement in South Viet-Nam is, as the Dang Lao Dong continually states publicly, a true "people's movement" that incidentally has been joined by a small number of Marxist-oriented nation. alists. A representative view in this vein is found in an article by Jeffrey Record in Trans-Action:

There is no single image that serves adequately to describe the Viet Cong. There are Viet Cong who are dedicated Marxists, many are expert practitioners of guerrilla warfare; some are land reformers; a few are hardened terrorists. Yet, as with most revolutionary 


\section{PATTERN OF ACTION}

movements in history, the bulk of those who make up the Viet Cong are rather common individuals possessing no extraordinary skills or talents. They rarely have a passionate attachment to the movement, much less a wider understanding of it. They join either because the circumstances give them little choice or because they see in the movement solutions to personal or local problems. ${ }^{3}$

However, determining the nature of the leaders' goals for such an enterprise by analyzing the rank-and-file participants in it assumes that there are no differences between either the leaders' goals and those of the participants or the leaders' level of sophistication and that of most of the participants. It also assumes that the leaders would consistently and openly articulate their hopes for what the ultimate result would be. Finding that a number of workers in a Chevrolet plant have no "passionate attachment" to, or "wider understanding" of, the production of automobiles would not justify a conclusion that General Motors is not in business for a profit or that the corporate body is not directed by a disciplined elite whose goals markedly differ from those of the workers.

The Party leaders possessed an esoteric picture of the Marxist millennium that was unintelligible and irrelevant to the masses. Even with the assistance of the mass organizations, the Party could not hope to use Marxist goals to motivate a sizeable following. Too, widespread induction of the masses to Marxism would ruin the Party's carefully cultivated image of the united front as a broad movement composed of Communists and non-Communists acting in concert to build a new society through reform-an image that the Dang Lao Dong projected in order to gain support outside Indochina. It was necessary, therefore, that the Party translate its apocalyptic vision into exoteric goals and tasks that could easily be grasped by the masses.

Thus, as an individual progressed from the ranks of the population at large in toward the core of the Party elite, his perception of the revolutionary goals changed. At successive points in the process of involvement, the concepts and implications of class struggle, the vanguard theory, and demo-

3. Jeffrey Record, "Viet Cong: Image and Flesh," TransAction (January, 1971), 52. 
cratic centralism became more clear, and his degree of political awareness or "revolutionary conciousness" expanded. It is only natural that within the revolutionary movement, the perception of goals would vary according to the particular vantage point of the individual.

The Party encouraged the population to perceive the issues as necessary reforms and offered the apparent opportunity for the villager to participate in the decision-making process through membership in the various mass organizations and special-interest groups. This involvement, in turn, caused the peasant to view the movement as a struggle of the National Liberation Front for economic, political, and social reform. The difficulty in fostering this exoteric goal was that, as a village Party secretary reported, "Once the people are satisfied about land, the movement degenerates." 4

To the Party, land and popular participation were only inducements to motivate the rural population, whose support the Party needed in order to destroy the numerically superior military and civil forces of the South Vietnamese Government. The land was not distributed by the Party to provide land to the tenant farmer-the Party instructed its cadre in no uncertain terms that the subject of land was only a propaganda device to be used to engage the services of the peasantry for the use of the Dang Lao Dong. The mass organizations that offered the illusion of a kind of participatory democracy were, in reality, directed by Party fractions and existed only to serve as "transmission belts" that enabled the Dang Lao Dong to control the masses.

This duality of goals was reflected in the Party's concept that the over-all struggle in South Viet-Nam was to be the kind of "dual revolution," outlined by Truong Chinh. The first revolution-a revolution in which the exoteric goal was "reform"-was to eliminate the "American imperialists and their lackeys," and for this task, the united front was formed to recruit the help of the bourgeoisie. In the second, or "socialist," revolution, the bourgeoisie would become the target to be destroyed as a class and tossed on the rubbish heap of history. If the lessons of China and North Viet-Nam obtain,

4. VCD 2, p. 60. 


\section{PATTERN OF ACTION}

land and labor would be collectivized and any remnants of political opposition ruthlessly smashed.

In summary, the peasant was induced to look upon the revolution as a means of reform and, as Jeffrey Record has pointed out, as a way of providing solutions to local problems. To the Party, which sponsored, organized, and directed the struggle, the goal was always unrestrained political power.

In a village in which the Party had fully consolidated its control, the entire range of human relations was monitored and controlled by the Party. Children were taught in Party schools and became members of the various children's groups or the Youth Liberation Association. Their mothers became members of the Women's Liberation Association, and their fathers joined the Farmers' Liberation Association. The men took their turns in standing guard at night, acted as porters, and set aside a portion of their harvest to feed the Main Force and Local Force units that came into the village.

The villager's world was shaped by the information controlled and altered by the Party; even familiar canals and villages were given new names that sharply defined the differentness between the areas dominated by the Dang Lao Dong and those controlled by the South Vietnamese Government. When one was in need of medical care, the Party furnished it, and if the treatment did not succeed, a Partysponsored association took care of the funeral. Crimes against the Party were ferreted out in the self-criticism sessions or reported by a suspicious neighbor or a security agent constantly on the watch for revolutionary backsliders. Justice, too, was meted out by the Dang Lao Dong.

Even if the peasant and his family were able to achieve the improbable feat of avoiding involvement in the various mass organizations, he had no other alternative non-Party groups with which to associate. The Party, representing as it did, "the People," brooked no social or political competition; by definition, any opposition, no matter how loyal, was "against the People." If the peasant wished to remain in his village, within the small world into which he had been born, he had no other choice but to go along and hope for the best.

In Dinh Tuong, the Dang Lao Dong was engaged in a process of reordering society for political purposes from the 
village upward while the South Vietnamese Government was apparently attempting to impose its control from Saigon downward. In the main, the Party was able to establish its new social order in the absence of any meaningful South Vietnamese Government contact with the villages. Besides the physical danger posed by occasional Government military patrols, no serious competitive political activity by the Saigon Government was cited by any village Party cadre who were interrogated. Although their natural tendency to focus on their own successes might have motivated such an omission, it seems logical that had the South Vietnamese Government impeded the Dang Lao Dong, the Party cadre would have reported it as they did the instances of Party difficulties with the Catholic and Cao Dai villages. In short, no evidence could be found in Dinh Tuong during the critical period studied that the South Vietnamese Government offered any systematic opposition to the Dang Lao Dong at village level or that it offered any workable alternatives to the villager.

In this near vacuum, the Dang Lao Dong created a modern government. It built and fielded competent armed forces, collected taxes, established schools, regulated commerce, and dispensed justice. It was a government that provided solutions to problems besetting the villager and maintained order with a minimum of physical force. It was also a government in which individual freedoms were most cynically crushed, a tyranny in which one participated and in which one did not have the option not to participate. It was a system in which policies were formed by a powerful elite that tolerated no opposition, no matter how peaceful.

Although there are vast differences between the villages of Dinh Tuong and those of Africa, Asia, and Latin America, a fundamental problem common to all is the means of social, political, and economic modernization. Standing between a dead past and a future yet to come, many traditional leaders cannot cope with problems their limited experience can scarcely define. Considering the events in the villages of Dinh Tuong, one is forced to ask, "Do alternatives exist that will satisfy the needs of the people but avoid the dehumanization of Marxism? Can other nations assist in the quest for alternatives?" 


\section{PATTERN OFACTION}

Cogent, practical alternatives to tyranny must exist; perhaps other nations can help to search for them. What is evident is that to resist oppression, the villages of the world must rely, not on arms alone, but upon the strength of their institutions, their leaders, their people. Given the nature of the village war as fought by the Dang Lao Dong in Dinh Tuong and as it is likely to be fought in modified forms elsewhere, a government's firepower, of itself, will not assure the success and survival of freedom. 



\section{BIBLIOGRAPHY}

\section{DOCUMENTS}

Lansdale, Edward G. "The Cao Dai." Memorandum submitted to U.S. Ambassador Bunker, Saigon, May, 1968.

Nguyen Be. "Chung Thuy: Study of the New Essence of Life." Mimeographed. Vung Tau, Viet-Nam: Ministry of Revolutionary Development, 1968.

Race Document 1006. Center for Research Libraries, Chicago.

Rand Corporation and Military Assistance Command, Vietnam J-2. Studies of the National Liberation Front of South Vietnam. Mimeographed. Saigon.

File No. DT-46 (I), July 15, 1965.

File No. DT-49 (III), January 20, 1966.

File No. DT-55 (II), July 29-30, 1965.

File No. DT-56 (I), July 30, 1965.

File No. DT-57 (III), July 29, 1965.

File No. DT-58 (II), December, 1965.

File No. DT-59 (I), January, February, 1966.

File No. DT-61 (III), July, 1965.

File No. DT-63 (III), July 29, 1965.

File No. DT-64 (I), March 3 and 8, 1965.

File No. DT-65 (III), December, 1965.

File No. DT-69 Supplement, October 27, 1965.

File No. DT-73, 1965 .

File No. DT-75 (I), 1965.

File No. DT-79 (I), 1965.

File No. DT-8o (II), 1965.

File No. DT-83 (I), September 5-6, 1965. 
File No. DT-84 (I), 1965.

File No. DT-85 (I), 1965.

File No. DT-86 (I), 1965.

File No. DT-87 (I), October 14, 1965.

File No. DT-88 (I), October 29, 1965.

File No. DT-92, 1965.

File No. DT-94 (II), 1965.

File No. DT-96 (I), October 3o, 1965.

File No. DT-98 (II), November 16, 1965.

File No. DT-99 (I), November 1965.

File No. DT-101 (II), 1965.

File No. DT-102 (I), January 11, 1966.

File No. DT-103 (II), December 30, 1965.

File No. DT-104 (I), January 13, 1966.

File No. DT-105 (II), January 28, 1966.

File No. DT-107 (II), 1966.

File No. DT-108 (I), March 19, 1966.

Vietnamese Communist Document 2. "Experiences in Turning $\mathrm{XB}$ Village in Kien Phong Province into a Combatant Village." Center for Research Libraries, Chicago.

Vietnamese Communist Document 7. Untitled directive concerning counterespionage activities of the Dang Lao Dong. Center for Research Libraries, Chicago.

Vietnamese Communist Document 15. Dang Lao Dong directive. Center for Research Libraries, Chicago.

Vietnamese Communist Document 18. Travel permit. Center for Research Libraries, Chicago.

Vietnamese Communist Document 27. Death notice. Center for Research Libraries, Chicago.

Vietnamese Communist Document 50. Regulations governing the Dang Lao Dong in South Viet-Nam. Center for Research Libraries, Chicago.

Vietnamese Communist Document 54. Regulations of the Vietnam Lao Dong Youth League. Center for Research Libraries, Chicago.

Vietnamese Communist Document 56. "Woman Proselyting Tasks." Center for Research Libraries, Chicago. 


\section{B I B L I O G R A P H Y}

Vietnamese Communist Document 75, 75A. “Five Rules to Follow." Center for Research Libraries, Chicago.

Vietnamese Communist Document 82. Bylaws of the Lao Dong Youth League. Center for Research Libraries, Chicago.

Vietnamese Communist Document 130. Directive on Information, Propaganda, Education and Cultural Activities for 1961. Center for Research Libraries, Chicago.

Vietnamese Communist Document 162. Labor Youth Association orientation. Center for Research Libraries, Chicago.

Vietnamese Communist Document 232. Dang Lao Dong directive. Center for Research Libraries, Chicago.

Vietnamese Communist Document 296. "Resolution: Some Land Tasks for the Year 1962." Center for Research Libraries, Chicago.

Vietnamese Communist Document 737. "Resolution on Motivating the People in Bien Hoa Province." Center for Research Libraries, Chicago.

Vietnamese Communist Document 749. Report on Dang Lao Dong land policies in the Mekong Delta. Center for Research Libraries, Chicago.

\section{BOOKS}

Brimmell, J. H. Communism in South East Asia. London: Oxford University Press, 1959.

Browne, Malcolm W. The New Face of War. New York: BobbsMerrill Company, Inc., 1965.

Burchett, Wilfred G. Vietnam: Inside Story of the Guerrilla War. New York: International Publishers, 1965.

Buttinger, Joseph. The Smaller Dragon. New York: Frederick A. Praeger, $195^{8 .}$

- Vietnam: A Political History. New York: Frederick A. Praeger, 1968.

Chen, King C. Vietnam and China, 1938-1954. Princeton: Princeton University Press, 1969.

Conley, Michael Charles. The Communist Insurgent Infrastructure in South Vietnam: A Study of Organization and Strategy. U.S. Department of the Army Pamphlet No. 550-106. Washington, D.C.: Government Printing Office, 1967.

Dallin, Alexander, and George W. Breslauer. Political Terror in Communist Systems. Stanford: Stanford University Press, 1970. 


\section{B I B L I O G R A P H Y}

Davison, W. P. Some Observations on Viet Cong Operations in the Villages. Santa Monica, Calif.: The Rand Corporation, 1967.

Durkheim, Emile. Suicide. Translated by John A. Spaulding and George Simpson. Glencoe, Ill.: The Free Press, 1951.

Elliott, David W. P., and W. A. Stewart. Pacification and the Viet Cong System in Dinh Tuong: 1966-1967. Santa Monica, Calif.: The Rand Corporation, 1969.

Fall, Bernard B. The Two Viet-Nams. New York: Frederick A. Praeger, 1966.

Guevara, Ernesto "Che." Guerrilla Warfare. New York: Frederick A. Praeger, 1967.

Hall, D. G. E. A History of South-East Asia. 3rd ed. New York: St. Martin's Press, 1968.

Hammer, Ellen J. The Struggle for Indochina: 1940-1955. Stanford: Stanford University Press, 1966.

Harrison, James P. The Communists and Chinese Peasant Rebellions. New York: Atheneum, 1969.

Hickey, Gerald C. Village in Vietnam. New Haven, Conn.: Yale University Press, 1964.

Ho Chi Minh. Ho Chi Minh on Revolution: Selected Writings, 1920-1966. Edited by Bernard B. Fall. Signet Books. New York: The New American Library, Inc., 1968.

Hoang Van Chi. From Colonialism to Communism: A Case History of North Vietnam. New York: Frederick A. Praeger, 1964 .

Honey, P. J. Communism in North Vietnam. Cambridge, Mass.: M.I.T. Press, 1963.

Hosmer, Stephen T. Viet Cong Repression and Its Implications for the Future. Lexington, Mass.: D. C. Heath and Company, 1970.

Lacouture, Jean. Ho Chi Minh. Translated by Peter Wiles. Vintage Books. New York: Random House, 1968.

Lartéguy, Jean. The Centurions. Translated by Xan Fielding. New York: E. P. Dutton and Company, 1962.

Leiden, Carl, and Karl M. Schmitt. The Politics of Violence: Revolution in the Modern World. Englewood Cliffs, N.J.: Prentice-Hall, Inc., 1968.

Mao Tse-tung. Chairman Mao Tse-tung On People's War. Peking: Foreign Languages Press, 1967. 


\section{B I B L I O G R A P H Y}

Mao Tse-tung On Guerrilla Warfare. Edited and translated by Samuel B. Griffith. New York: Frederick A. Praeger, 1961.

- Selected Military Writings of Mao Tse-tung. Peking: Foreign Languages Press, 1967.

McAlister, John T., Jr. Vietnam: The Origins of Revolution. Doubleday Anchor Books. Garden City, N.Y.: Doubleday \& Company, Inc., 1971.

Mitchell, Edward J. Inequality and Insurgency: A Statistical Study of South Vietnam. Santa Monica, Calif.: The Rand Corporation, 1967.

O'Ballance, Edgar. The Indo-China War, 1945-1954: A Study in Guerrilla Warfare. London: Faber \& Faber, 1964.

O’Neill, Robert J. General Giap: Politician and Strategist. New York: Frederick A. Praeger, 1969.

Pike, Douglas. Viet Cong. Cambridge, Mass.: M.I.T. Press, 1966.

Rathausky, Rima, ed. Documents of the August 1945 Revolution. Canberra: The Australian National University, 1963.

Reischauer, Edwin O., and John K. Fairbank. East Asia: The Great Tradition. Boston. Houghton-Mifllin Company, 1960.

Sansom, Robert L. The Economics of Insurgency in the Mekong Delta of Vietnam. Cambridge, Mass.: M.I.T. Press, 1971.

Singer, Floyd L. Control of the Population in China and Vietnam: The Pao Chia System Past and Present. China Lake, Calif.: U.S. Naval Ordnance Test Station, 1964.

Tawney, R. H. Land and Labor in China. Boston: Beacon Press, 1966.

Tongas, Gerard. L'enfer Communiste du Nord Vietnam. Paris: Les Nouvelles Editions debress, 1960.

Truong Chinh. Primer for Revolt: The Communist Takeover in Viet-Nam. New York: Frederick A. Praeger, 1963.

Vo Nguyen Giap. Banner of People's War, the Party's Military Line. New York: Praeger Publishers, 1970.

The Military Art of People's War. Edited by Russell Stetler. New York: Monthly Review Press, 1970.

- People's War, People's Army. New York: Frederick A. Praeger, 1962.

\section{ARTICLES AND ESSAYS}

Ahmad, Eqbal. "Revolutionary War and Counterinsurgency." National Liberation: Revolution in the Third World. Edited 


\section{B I B L I O G R A P H Y}

by Norman Miller and Roderick Aya. New York: The Free Press, 1971.

Bredo, William. "Agrarian Reform in Vietnam: Vietcong and Government of Vietnam Strategies in Conflict." Asian Survey, 10, 8 (August, 1970), 738-50.

Carver, George A., Jr. "The Faceless Viet Cong." Foreign Affairs, 44 (April, 1966), 347-72.

- "The Real Revolution in South Viet-Nam." Foreign Affairs, 43 (April, 1965), 387-408.

Fall, Bernard B. "Ho Chi Minh, Like It or Not." Man, State, and Society in Contemporary Southeast Asia. Edited by Robert O. Tilman. New York: Praeger Publishers, 1969.

- "Indochina Since Geneva." Pacific Affairs, 28 (September, 1955), 3-25.

- "Viet Nam In The Balance." Foreign Affairs, 44, 1 (October, 1966), 1-18.

Grose, Peter. "Vietcong's 'Shadow Government' in the South." New York Times Magazine (January 24, 1965), $23-67$.

Hammer, Ellen J. "The Limits of Political Action." Pacific Affairs, 35 (Spring, 1962), 24-36.

- "Progress Report on Southern Viet Nam." Pacific Affairs, 30 (September, 1957), 221-35.

Janos, Andrew C. "Authority and Violence: The Political Framework of Internal War." Internal War. Edited by Harry Eckstein. New York: The Free Press, 1964.

Ladejinsky, Wolf I. "Agrarian Reform in the Republic of Vietnam." Vietnam: Anatomy of a Conflict. Edited by Wesley R. Fishel. Itasca, Ill.: F. E. Peacock Publishers, Inc., 1968.

Le Nam Thang. “Grasp Basic Principles of People's War." Thu Do Hanoi (October 13, 1965), 1, 3. Reproduced, U.S. Department of Commerce, Translations of Political and Sociological Information on North Vietnam, No. 237. Joint Publications Research Service, November 30, 1965.

Lin Piao. "Long Live the Victory of People's Warl" Peking Review, 36 (September 3, 1965), 9-30.

Mao Tse-tung. "How to Differentiate the Classes in the Rural Areas." Selected Works. English edition. Vol. I. Peking: Foreign Languages Press, 1961.

. "Talk with the American Correspondent Anna Louise Strong." Selected Works. English edition. Vol. IV. Peking: Foreign Languages Press, 1961. 


\section{BIBLIOG R A P H Y}

Mus, Paul. "The Role of the Village in Vietnamese Politics." Pacific Affairs, 22 (September, 1949), 265-72.

Phuong Anh Trang. "Land Reform of Viet Nam Through History." Vietnam Bulletin, 5 (March 22, 1971), 2-4.

Pike, Douglas. "How Strong is the NLF?" The Reporter, 34 (February 24, 1966), 20-24.

Prosterman, Roy L. "Land-to-the-Tiller in South Vietnam: The Tables Turn." Asian Survey, 10, 8 (August, 1970), 751-64.

Race, Jeffrey. "How They Won." Asian Survey, 10, 8 (August, 1970), 628-50.

- "The Origins of the Second Indochina War." Asian Survey, 10, 5 (May, 1970), 359-82.

Record, Jeffrey. "Viet Cong: Image and Flesh." Trans-Action (January, 1971), 47-52.

Rostow, W. W. "Guerrilla Warfare in Underdeveloped Areas." Marine Corps Gazette (January, 1962), 47-50.

Sacks, I. Milton. "The Indigenous Roots of Vietnamese Nationalism." Vietnam: Anatomy of a Conflict. Edited by Wesley R. Fishel. Itasca, Ill.: F. E. Peacock Publishers, Inc., 1968.

Selden, Mark. "Revolution and Third World Development." National Liberation: Revolution in the Third World. Edited by Norman Miller and Roderick Aya. New York: The Free Press, 1971.

Thornton, Thomas Perry. "Terror as a Weapon of Political Agitation." Internal War. Edited by Harry Eckstein. New York: The Free Press, 1964.

Tran Minh Tan. "Experiences of the Three Responsibilities in Hai Duong." Nhan Dan (October 23, 1965), 1. Reproduced, U.S. Department of Commerce, Translations of Political and Sociological Information on North Vietnam, No. 237. Joint Publications Research Service, November 30, 1965.

Vo Nguyen Giap. "Understand the Military Policies of the Party and Go On to Win New Victories." Tuyen Huan, 10 (October, 1965), 17-45. Reproduced as Vo Nguyen Giap On Understanding the Party's Military Policies, U.S. Department of Commerce, Translations of Political and Sociological Information on North Vietnam, No. 238. Joint Publications Research Service, December 1, 1965.

Vu Van Thai. "The Development of the Revolution." Asia (Winter, 1966), 22-30.

Vuong Si Dinh. “Air Defense in T. Rural Community, Nghe An.” Qwan Doi Nhan Dan (October 8, 1965), 3. Reproduced, 


\section{B I B L I O G R A P H Y}

U.S. Department of Commerce, Translations of Political and Sociological Information on North Vietnam, No. 232. Joint Publications Research Service, November 18, 1965.

Wolf, Charles, Jr. "Insurgency and Counterinsurgency: New Myths and Old Realities." Yale Review, 56 (December, 1966), 225-41.

\section{GOVERNMENT PUBLICATIONS}

An Introduction to Vietnam. Washington, D.C.: Embassy of Vietnam, n.d.

U.S. Department of State. Aggression from the North: The Record of North Viet-Nam's Campaign to Conquer South VietNam. Department of State Publication No. 1839. Washington, D.C.: Government Printing Office, 1965.

A Threat to the Peace: North Viet-Nam's Effort to Conquer South Viet-Nam. Department of State Publication No. 7308. Washington, D.C.: Government Printing Office, 1961.

U.S. Senate, Committee on Foreign Relations. Viet Nam, Cambodia and Laos: Report by Senator Mike Mansfield. Washington, D.C.: Government Printing Office, 1955. 


\section{INDEX}

A

Agricultural tax: origins, 97; scales, 99; calculation of, 99100; political significance of, 102-3; and Destruction of Oppression, 134-35. See also Taxation

Agricultural loans: in Cai Be District, 63-64

Annam Communist Party, 12

Assassination. See Destruction of Oppression

\section{B}

Backbone elements: in support of taxation, 98-99; exertion of social pressures by, 115-16, 119 . See also Mass organizations

Binh van: definition of, 53; and U.S. Embassy, 63; in struggle movement, 118-19

Buddhists: resistance to Dang Lao Dong, 69, 132

C

Cai Be District: Reduction of Prestige campaign in, 61, 62: Dang Lao Dong seizure of Hau My village, 63-64; labor exchange in, 114, 115

Cai Lay District: Destruction of Oppression campaign in, 5657; contributions to Dang Lao Dong in, 96-97; agricultural tax in, 97; conscription in, 125

Cambodia: resistance to Vietnamese expansion, 3

Cao Dai sect: resistance to social disorientation, 68-69, 130, 13132; mentioned, 21

Catholic: Dang Lao Dong conflict with, 45; village chief, 64 ; resistance to social disorientation, 68-70, 97, 130, 131-32; assassination of, 69-70; Church lands, 70; Dang Lao Dong membership requirements

for, 89

Censorship: of radio broadcasts, 110; of mail, 110-11; of place names, 111

Cham wars, 1-2

Chau Thanh District: Destruction of Oppression, 56, 58; contributions to Dang Lao Dong in, 96-97; daily guerrilla schedule in, 107; struggle movement in, 120

China: early relations with, 1-3 passim; revolutionary doctrine of, 15, 23, 25; pao chia system of surveillance, 109

Cho Gao District: Destruction of Oppression in, 59; Dang Lao Dong recruiting in, 85-86; Labor Youth Association in, 8889; Dang Lao Dong government in, 93-94; extent of Dang Lao Dong control of, 94; contributions to Dang Lao Dong in, 96-97; agricultural tax scales in, 99; labor exchange in, 114; military desertion in, 127-28; mentioned, 111

Civil Affairs Committee: clandestine formation of, 48 ; clandestine communications of, 49-50; organization of subordinate elements, 52; and Destruction of Oppression, 59, 60; and assassination of Catholics, 69; expansion of, 91

Clandestine activities: organizations, 22, 47, 48-49, 81-82, 129; base areas, 44-45; "line casting position," 45; population surveys, 45-46; economic analyses, 46 ; enemy strength assessments, 46-47; recruiting, 47-48; Dang Lao Dong internal security measures, 48-50; communications system, 49-50 
Coercive power, $133-36$

Communal determination of taxes, 97-99

Communications: clandestine, $49-$ 50; liaison stations, 122

Confucianists: and vulnerability to social disorientation, 69,132

Conscription: beginning of, 12425; policy, 125; use of force in, 125-26

Contributions and Dang Lao Dong finances, 96-97

Criticism, self-criticism, 117-18

D

Dan van: definition of, 53 ; in struggle movement, 118; mentioned, 63

Dang Lao Dong: relationship to National Liberation Front, ix, $38-39,42-43,72-73,92-96$, 129; and Lien Viet, 17; founding of, 17; revolutionary philosophy, 22-41, 51, 104, 136-39; and People's Revolutionary Party, 39-41; view of 1954 Geneva agreements, 43-44; land reform objectives of, 6568; and landlords, 67, 90; power relationship with Saigon Government, 70; and Farmers' Liberation Association, 74-75, 81-82; sexual promiscuity and the, 78, 117-18; control of mass organizations, 80-84; expansion of village apparat, 84-92, 130; membership requirements, $84-86,89-91$; and village government, 92-96; media of, 111; control of members, 116-18; extent of control in Dinh Tuong Province, 128; symbiotic relation with village, 132; use of normative and coercive power by, $133-36$

Destruction of Oppression: beginning of, 55; purposes of, 55-56; results of, 57-58, 61, 131-32; and Civil Affairs Committee, $59,59-60$; number of deaths, 60; misconceptions of, 64-65; and Catholics, 69-70; and agricultural tax, 134-35, 136. See also Terror

Dich van: definition of, 53; among
Catholics and Cao Dai, 69; in struggle movement, 118-19; mentioned, 63

Dong Minh Hoi, 15

F

Farmers' Liberation Association: relationship to Dang Lao Dong and National Liberation Front, 74-75; membership requirements, 75; organization of, 7576; control by Dang Lao Dong, 80-82; and labor exchange, 114-15; mentioned, 79, 85, 94. See also Mass organizations

Finance section, 95

Foster Mothers' Association: Ho Chi Minh and, 77; operation of mail and liaison services, 122. See also Mass organizations

Fractions: Viet Minh "sections," 24; used in control of mass organizations, 24, 73, 80-82, 93 France: early relations with VietNam, 4-7

Funeral aid association, 76, 139. See also Mass organizations

\section{G}

Giao Duc District: women's organizations in, 78; Dang Lao Dong recruiting in, 86 ; movement restrictions in, 113

H

Ho Chi Minh: pre-Communist life, 9-10; founding of Vietnamese Communist movement, 9-16 passim; at Socialist Party Congress of Tours, 9-10; founding of French Communist Party, 10; Comintern mission to China, 10-12; training of revolutionaries, 10-11; founding of Indochinese Communist Party, 13; recalled to Moscow, 13; unitedfront policy of, 14-15; dissolution of Indochinese Communist Party, 16; on relations with the bourgeoisie, 29-30; on phases of military struggle, 34-35; on self-criticism, 117; mentioned, $20,21,67$

Hospitals: in villages, 122 


\section{N D E X}

I

Indochinese Communist Party:

founding, 13; and Popular

Front, 14; relationship to Viet

Minh, 14-15; My Tho uprising,

14; dissolution of, 16

L

Labor Exchange Squads, 114-15

Labor Youth Association: role of, 86; name change of, $86-87$; relationship to Dang Lao Dong, $86,87,87-88$, 130; membership requirements, 87 ; bylaws, 87; organization of, 87; control by Dang Lao Dong, 87-88; growth of, 88-89; Dang Lao Dong recruiting in, 89 ; role in village government, 94; tax-raising efforts of, 98 ; mentioned, 84

Land: communal lands, 6; redistribution of, 6,36 ; factors causing landlessness, 6-7; ownership of, 7 ; rents, $7-8,100$; absentee landlords, 8; reform in North Viet-Nam, 21, 29, 30, 67; as Dang Lao Dong tactic in South Viet-Nam, 65-68, 130; collection of back-rents, 66-67; taxes on, 100

Landlords: absentee, 8; peasant attitudes toward, 8; Communist policy concerning, 29-30; membership in Dang Lao Dong, 90

Le Duan: on National Liberation Front, 38

League of Indochinese Communists, 12

Liberation associations: support of conscription by, 126; criticism of deserters by, 127. See also Mass organizations

Lien Viet, 16, 17

Lin Piao: on united front, 37

Local Forces: missions of, 36,47 ; supplies from villages, 120-23; billeting of, 121; mentioned, 36 . See also Military forces

Long Dinh District: Destruction of Oppression in, 56; Reduction of Prestige in, 62; relationship of Dang Lao Dong and $\mathrm{Na}$ tional Liberation Front in, 82; village government in, 92-93; military desertion in, 127

M

Main Forces: description of, 36; billeting of, 121; movement patterns of, 122-23; composition of, 124; in Cai Lay District, 125; growth of, 128; mentioned, 36,47 . See also Military forces

Mansfield, Mike, Senator: on Viet Minh clandestine organizations, 22

Mao Tse-tung: on support of population, 28 ; on protracted warfare, 32-33; on armed forces, 35-36; definition of rural economic classes, 46; classification of propaganda, 52; on control of revolutionary movements, 123; mentioned, 23, 31, 36

Mass organizations: and National Liberation Front, 38-39; definition of, 72-73; Che Guevera on, 73; purposes of, 73-74; in Nghe An Province, 74; children's groups, 79-80; control by Dang Lao Dong, 80-84, 138; recruits for Dang Lao Dong, 81, 84-86; appeals of, 85; social pressures exerted by, 93, 96, 97-99, 115$16,126,127,130$; civilian guerrillas as members of, 107; in struggle movements, 119; growth of, 135; mentioned, 82, 108. See also Backbone eloments; Farmers' Liberation Association; Foster Mothers' Association; Funeral aid association; Liberation associations; Sisters' Association; Women's Liberation Association; Youth Liberation Association

Migration of Vietnamese people: influence on settlement patterns, 2; societal impact of, 4-5; Western influence on, 4-8

Military affairs section: functions of, 94; control of village guerrillas by, 105-6; movement control by, 113; supplies for regular military units, 121; elimination of, 124; mentioned, 127 Military forces: Viet-Nam Propa- 


\section{N D EX}

ganda and Liberation Unit, 16; village military units, $35-36$, 104-7; relationship to Dang Lao Dong, 40; Main Forces, 105; Local Forces, 105; sizes of village units, 105; use of village units, 106; advantages of voluntary military service, 106-7, 126; daily schedule of village guerrilla unit, 107; censorship of mail in, 110-11; support derived from villages, 120-28; combat casualties, 124, 127; desertion, 127-28. See also Local Forces; Main Forces

Military proselyting section:

functions, 94-95; use of bribes, 106; use of land, 112; in support of conscription, 126

National Liberation Front: relationship to Dang Lao Dong, ix, $38-40,42-43,72-73,92-96$, 129; origins of, $38-39$; organization, 39; mentioned, 115. See also United front

Nghe An Province: Nghe An-Ha Tinh soviets, 13; mass organizations in, 74; mentioned, 2, 108

Nguyen Huu Tho: description of struggle movement objective, 119

Nguyen-Trinh wars (1497-1570), 2-3

Normative power, $133-36$

\section{$\mathbf{P}$}

Pao chia: origins of, 109; purpose of, 109. See also Surveillance

Party Chapter Committee: organization and responsibilities, 9192; censorship of mail by, 11011; restriction of travel by, 112; coordination of military supply system, 121-22; and liaison stations, 122; and conscription, 124; mentioned, 96, 109, 124

People's Liberation Committees: relationship to Dang Lao Dong, 39-40; composition of, 93-94; mentioned, 92, 109

People's Revolutionary Party: ori- gins, 39-41; relationship to Dang Lao Dong, 39-41; and the National Liberation Front, 39-41

People's Revolutionary Youth Group. See Labor Youth Association

Population control. See Censorship; Re-education; Terror; Travel restrictions

Plain of Reeds: Dang Lao Dong clandestine bases in, 44

Propaganda: propaganda section organization, 52; classification of activities, 52-53; use of mass organizations for, 73-74, 79; secret propaganda, 81-82; and information manipulation, 11011; staging of spontaneous mass meetings, $119-20$

\section{$\mathbf{R}$}

Recruitment techniques, 84-86

Reduction of Prestige: in Cai Be District, 61-62; in Long Dinh District, 62; implications of, 131-32; mentioned, 110. See also Terror

Re-education: support of tax collection by, 102; use in proselyting campaigns, 112-13; in support of conscription, 125-26

Regroupees: definition of, 22; organizations, 22; political training of, 29; infiltration into South Viet-Nam, 38; land provided to, 112; mentioned, 66

Revolutionary doctrine: dual revolution, 11, 29-31, 37; Chinese influence, 15, 23, 25, 31-33 passim, 109; dominance of nonCommunist organizations, 2325; use of fractions, $24,73,80-$ 84; control of population, 2531; role of Dang Lao Dong in society, 25-26; phases of political domination, 26-27; role of military policy, 27-28; protracted struggle, 31-35; impact of prolonged struggle on non-Communist opponents, 3334; phases of armed struggle, 


\section{N D E X}

34-35; revolutionary armed forces, $35-36$

\section{$\mathbf{S}$}

Security section: preparation of dossiers, 54, 82; missions of, 56 , 95; arrests of spies, 69; surveillance of population by, 10910; mentioned, 52

Sisters' Association: role of, 78 . See also Mass organizations

Social disorientation: and Catholic peasants, 68-70, 97, 130, 131-32; and Cao Dai sect, 6870, 130, 131-32; implications of, 131-33

Soldiers' Mothers' Association, functions of, 77-78, 95

Struggle movement, 118-20

Surveillance: role of security section, 95, 109-10; of individuals, 108-10; mutual, 109; categorization of security threats, 10910. See also Pao chia

\section{T}

Taxation: implications of, 95-96; beginning of, 96-97; communal determination of, 97-99; market tax, 100; production tax, 101; liberation bonds, 101; revenues from, 101; increases in, 101-2; exemptions, 102; coercion in collection, 102. See also Agricultural tax

Terror: in collection of taxes, 102; enforcement, 115-16; People's Courts, 102, 115-16. See also Destruction of Oppression; Reduction of Prestige

Thanh Nien: relationship to Communist Party, 10; newspaper of, 11; movement to Hong Kong, 12; May 1929 Congress of, 22; disbandment of, 12

Travel restrictions: enforcement of, 112-13; movement passes, 113; impact of, 113-14

Truong Chinh: on domination of non-Communist organizations, 23-24; on Dang Lao Dong failure of 1954, 26; necessity for flexible policies, 29; theory of dual revolution, 30, 138-39; on

protracted warfare, 33-34;

mentioned, 37, 67

U

United front: Vo Nguyen Giap on, 14; double-decked, 16-17; Lin Piao on, 37; Dang Lao Dong perceptions of, 36-41. See also National Liberation Front; Viet Minh

United States Embassy: bombing of, 63

V

Viet Minh: origins, 14-15; political goals of, 15; and Dong Minh Hoi, 15; armed elements of, 16; land reform program of, 66 .

See also United front

Vietnamese Communist Party, 13 Village Party secretary: approval of Dang Lao Dong membership applications, 89; and Dang Lao Dong village executive committee, 92; and tax collection, 102; and travel restrictions, 113; military authority of, 121, 123, 124-25; burial of combat casualties, 122; and military deserters, 127-28

VNQDD, 12

Vo Nguyen Giap: on dual revolution, 11; on use of united front, 14; on revolutionary mission of Dang Lao Dong, 23; on revolutionary warfare, 24-25; role of the peasantry, 25, 28; on process of political domination, 26 ; and political-military relationships, 27-28; on protracted warfare, 33; phases of armed struggle, 34; on civilian guerrillas, 107; mentioned, 27

Voice of America, prohibited by Dang Lao Dong, 110

W

Wang An-shih, and pao chia, 109 Women, membership in Dang Lao Dong, 90-91

Women's Liberation Association: origin of, 38,76 ; organization of, 76 ; responsibility of mem- 


\section{N D EX}

bers, 76-77; restrictions on size, 77; Dang Lao Dong analysis of, 78; mentioned, $74,85,94$. See also Mass organizations

$\mathbf{Y}$

to Dang Lao Dong and National Liberation Front, 79; membership requirements of, 79; duties of members, 79; recruitment into Dang Lao Dong, 85-86; and Labor Youth Association,

Youth Liberation Association: origin of, 38; purpose of, 78-79; organization, 79; relationship

87-88; mentioned, 85, 94, 116. See also Mass organizations 



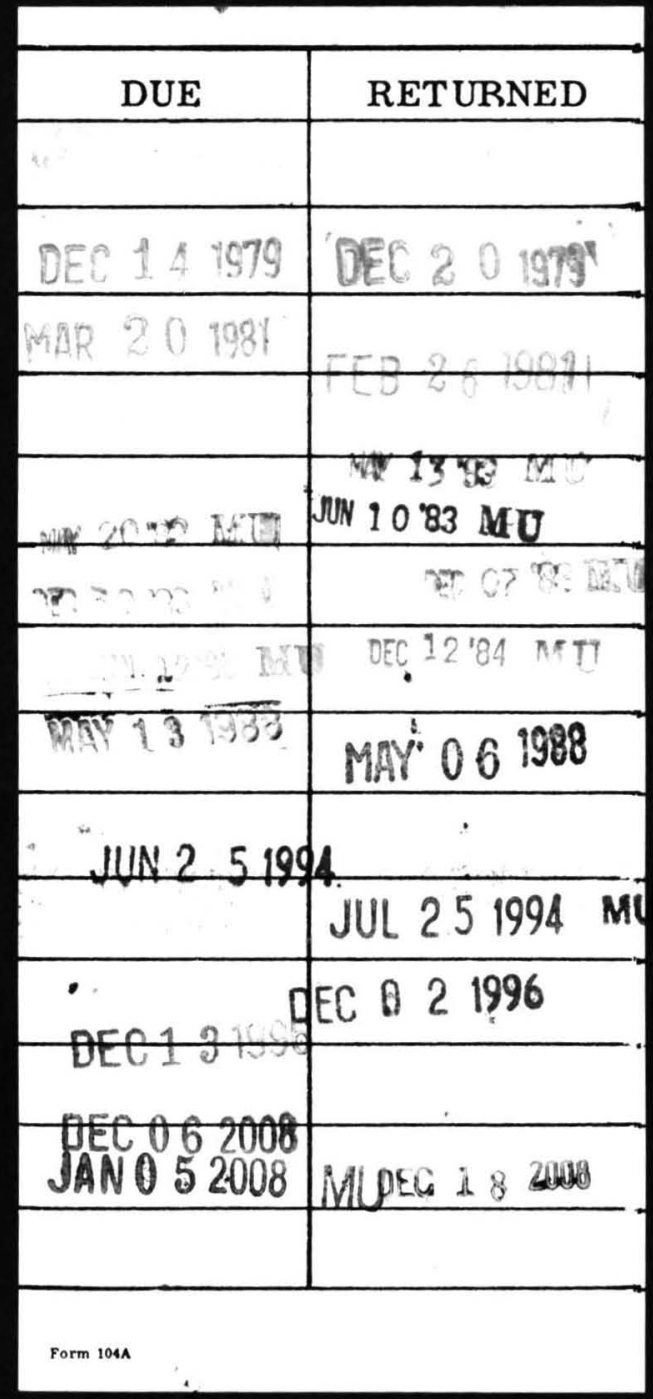




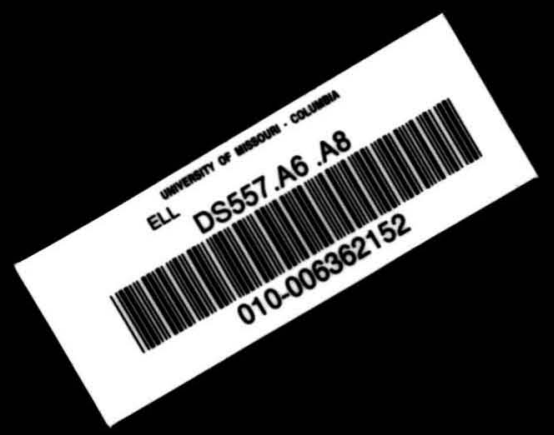

DS
557
.$A 6$
.$A 8$
$j 71477$


